\title{
Geospatial Framework for the Use of Natural Resource Extraction in Public Private Partnerships
}

Juan de Dios Barrios

West Virginia University

Follow this and additional works at: https://researchrepository.wvu.edu/etd

\section{Recommended Citation}

Barrios, Juan de Dios, "Geospatial Framework for the Use of Natural Resource Extraction in Public Private Partnerships" (2013). Graduate Theses, Dissertations, and Problem Reports. 479.

https://researchrepository.wvu.edu/etd/479

This Dissertation is protected by copyright and/or related rights. It has been brought to you by the The Research Repository @ WVU with permission from the rights-holder(s). You are free to use this Dissertation in any way that is permitted by the copyright and related rights legislation that applies to your use. For other uses you must obtain permission from the rights-holder(s) directly, unless additional rights are indicated by a Creative Commons license in the record and/ or on the work itself. This Dissertation has been accepted for inclusion in WVU Graduate Theses, Dissertations, and Problem Reports collection by an authorized administrator of The Research Repository @ WVU.

For more information, please contact researchrepository@mail.wvu.edu. 


\title{
Geospatial Framework for the Use of Natural Resource Extraction in Public Private Partnerships
}

\section{Juan de Dios Barrios}

\author{
Dissertation submitted \\ to the College of Civil and Environmental Engineering \\ At West Virginia University
}

in partial fulfillment of the requirements for the degree of

Doctor in Philosophy in

Civil Engineering concentration in Transportation

David Martinelli Ph. D. Chair

Lloyd J. French Ph.D.

Leonel Medellin Ph.D.

Andrew Nichols Ph.D.

Avinash Unnikrishnan Ph.D.

Morgantown, West Virginia October 2013

Keywords: Public Private Partnerships, Geospatial Sciences, King Coal Highway

Copyright Juan de Dios Barrios 


\section{Abstract \\ Geospatial Framework for the Use of Natural Resource Extraction in Public Private Partnerships by Juan de Dios Barrios}

Resources for the maintenance and expansion of existing highway infrastructure are scarce.

Public Private Partnerships (PPP) are feasible solutions to the concern of lagging investment. PPP are increasingly used for the procurement of services and goods, because of their flexibility and ability to channel private resources. This research addresses the possible implementation of a barter approach in Public Private Partnerships (PPP), which includes natural resources for trade model to offset costs.

Federal law permits the extraction of coal when it is a byproduct of the construction process, coal which under normal circumstances would not be economically feasible to extract. West Virginia law allows PPP to extract coal by surface mining when they develop road beads for new highways. There is no exchange of funds between the coal company and the West Virginia Department of Transportation; the benefits are derived entirely from the construction cost savings for roadbed construction.

This dissertation develops a geospatial method to quantify the availability of natural resources along predetermined roadway alignments. The methodology is divided in three phases: Macroscopic (Level I), Mesoscopic (Level II) and Microscopic (Level III), for the King Coal Highway. The process considers laws and industry best practices in the calculation. The research outcome suggests that there are segments of the road with enough, as well as segments of the road without enough coal. 


\section{Acknowledgements}

The author would like to express the support of the following organization and individuals for their support and guidance.

\section{West Virginia University}

Dr. David Martinelli, Dr. Avinash Unnikrishnan, Dr. Leonel Medellin and Dr. Lloyd J. French.

Nick J. Rahall, II Appalachian Transportation Institute

Mr. Robert Plymale, Mr. David Lawson M.S., Dr. Peter J. Dailey, Dr. Junwook Chi

Marshall University

Dr. Andrew Nichols, Dr. James O. Brumfield

West Virginia Department of Transportation

David E. Cramer, PE. Brian Carr, PE

West Virginia Property Tax Division

Tyler Bragg, GISP

West Virginia Geological Survey

Dr. Mitch Blake

Strategic Solutions, LLC

Michael C. Castle, JD.

The author appreciated the support of the following people:

Jeanie Budrus M.A.

Stephanie Walker M.A.

Dr. Donna Davis

Dr. William Edwards 


\section{Dedication}

I would like to formally dedicate this doctoral dissertation to my wife, Cathie, who has been my foundation and main source of encouragement; my daughters, Claire and Audrey, to follow your dreams and never give up; my mother in law, Donna, and father in law, Will, for supporting me in this endeavor; and my sisters, Carmen, Ruth, Rita, Ana Luisa and Bertha for cheering me on through this time. I also dedicate this work to the memory of my father Dr. Juan de Dios Barrios, my mother Rita Teresita Barrios, my grandmother Mama Tucha, and my mentor Dr. James O. Brumfield. 


\section{Contents}

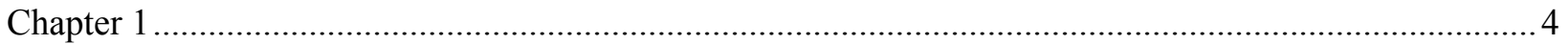

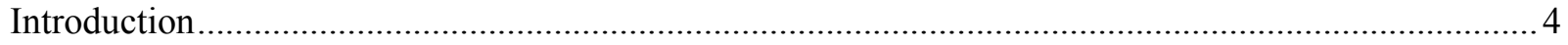

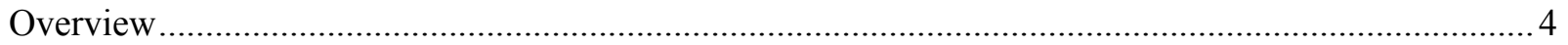

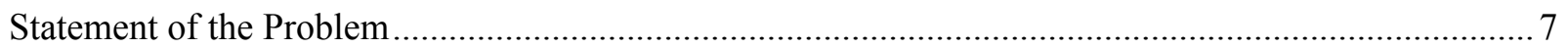

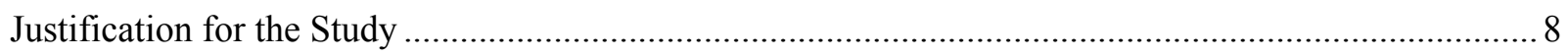

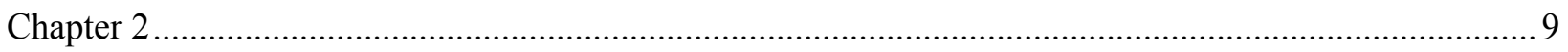

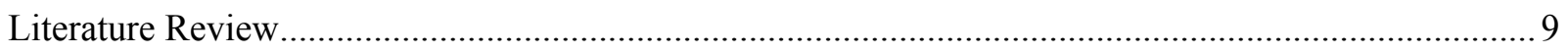

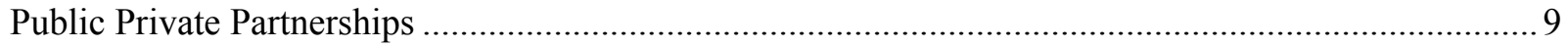

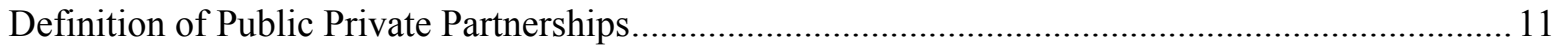

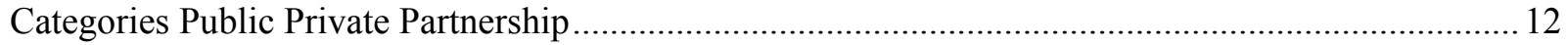

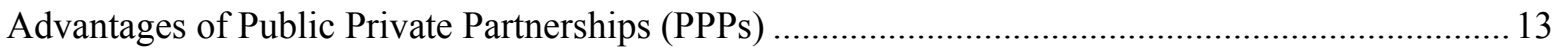

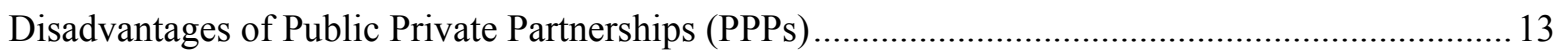

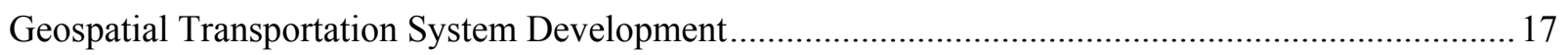

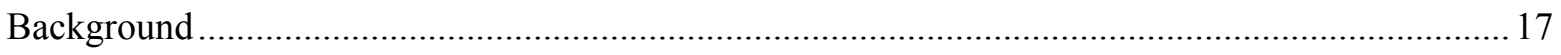

Regional Analysis and Modeling ....................................................................................... 19

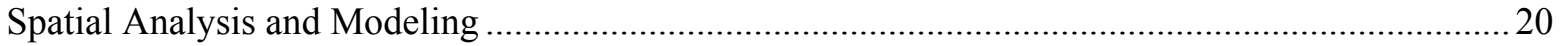

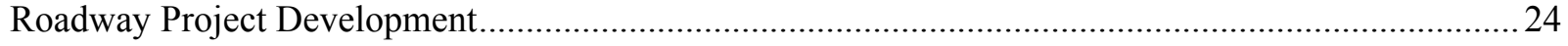

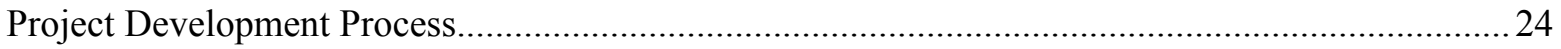

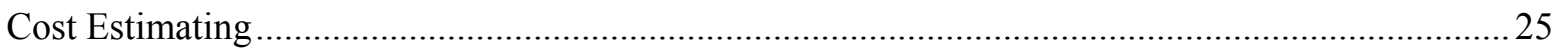

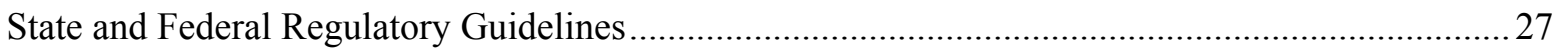

West Virginia Department of Transportation Project Development Process ................................... 28

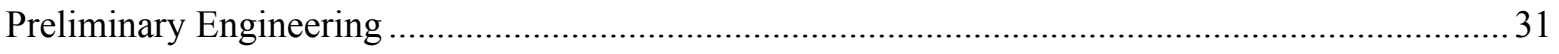

Right of Way, Preliminary Engineering and as the project goes ................................................. 32

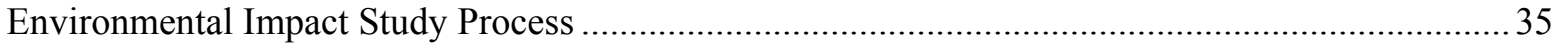

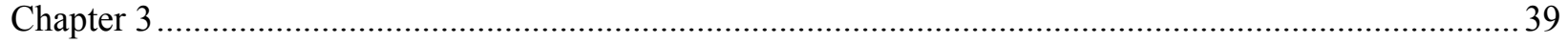

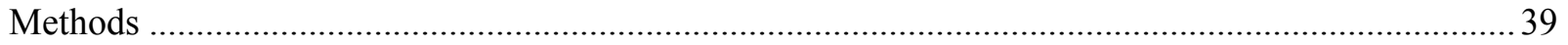

Deployment Using Geospatial Modeling to Evaluate Project Benefits ............................................ 42

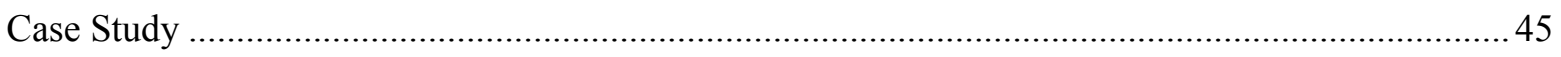

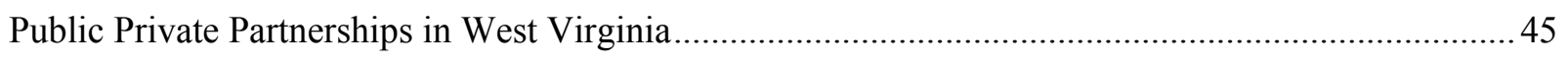

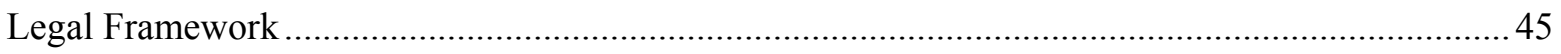

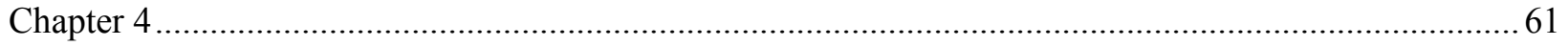




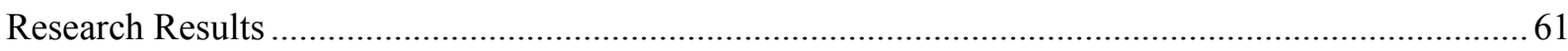

1. Developed a Geospatial Coal Map for the King Coal Highway............................................. 61

2. Developed a Geospatial Analysis Method to Relate Coal Data to Roadway Alignment for the

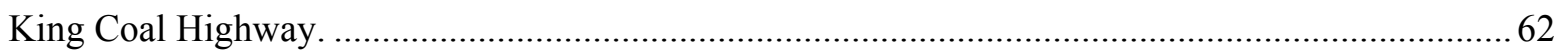

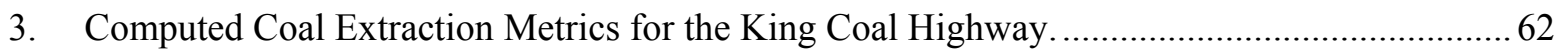

4. Documented the Methodology and Procedure for Producing the Metrics................................. 63

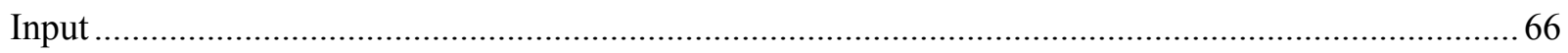

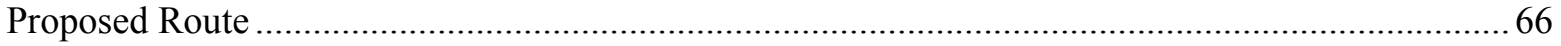

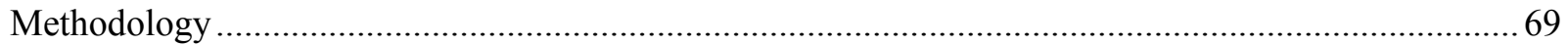

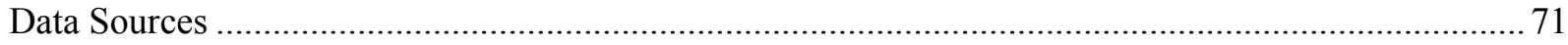

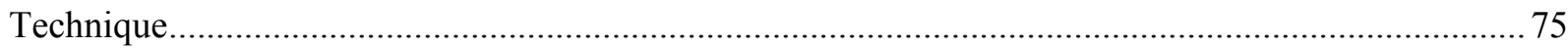

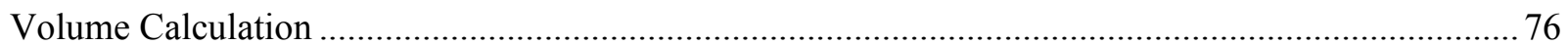

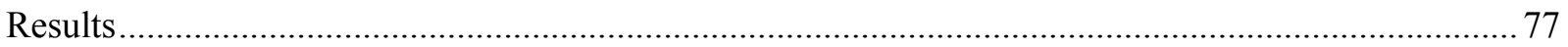

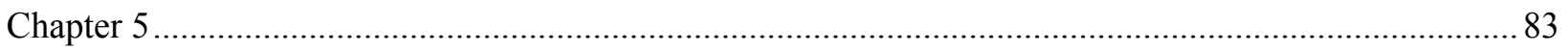

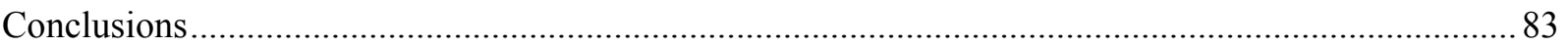

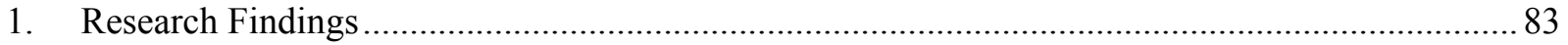

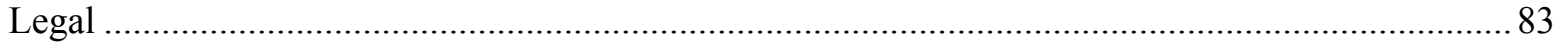

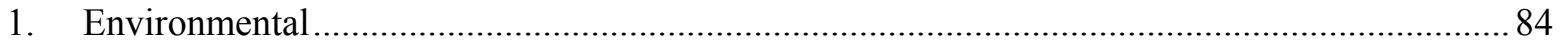

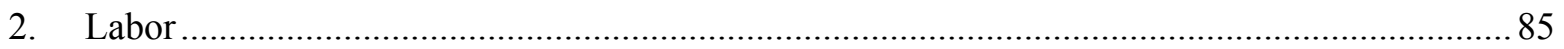

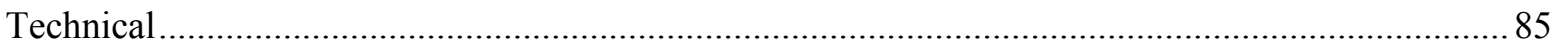

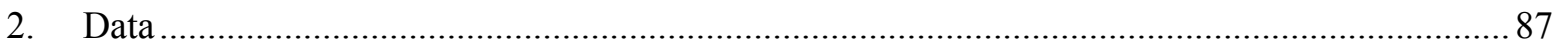

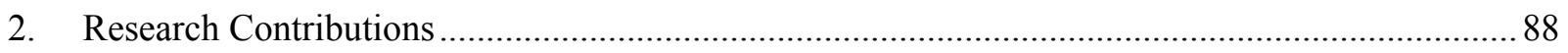

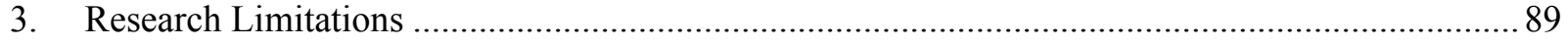

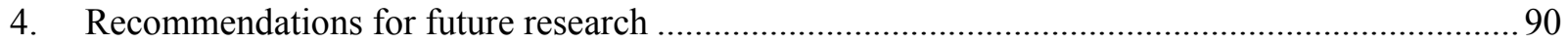

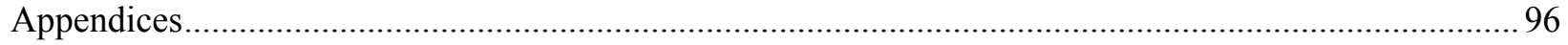

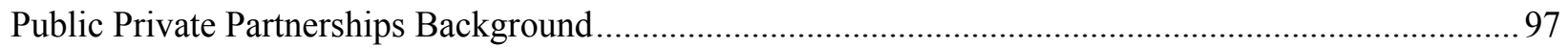

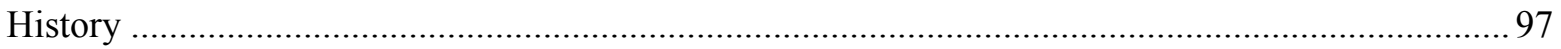

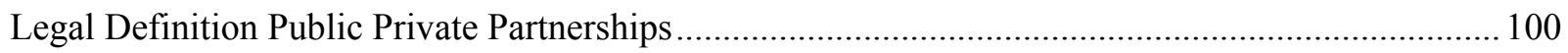

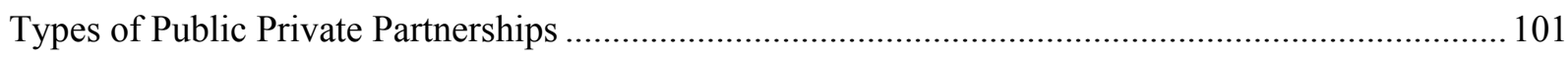

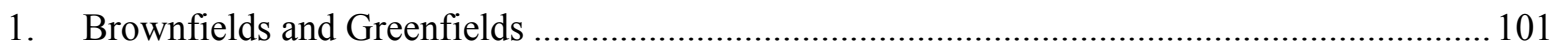

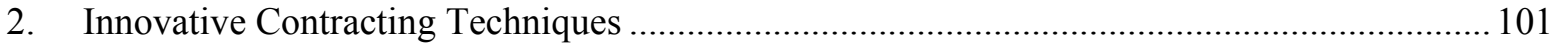

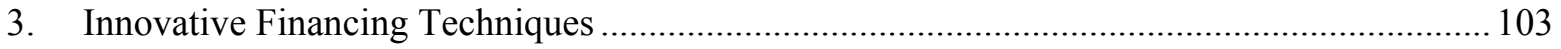

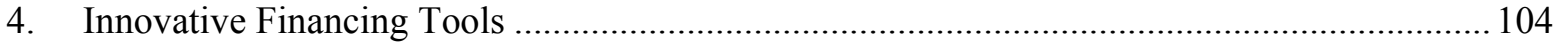




\section{List of Figures}

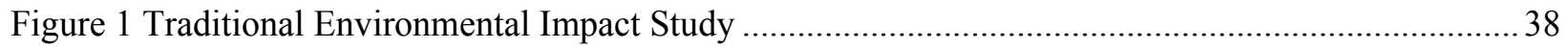

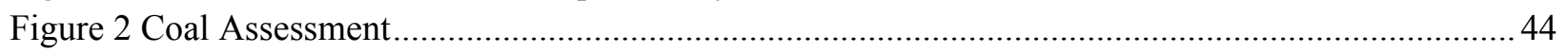

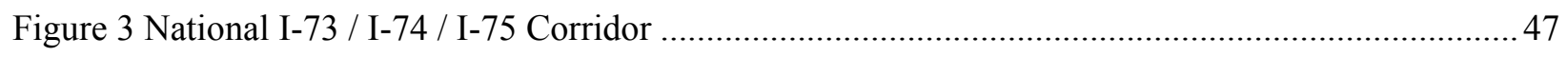

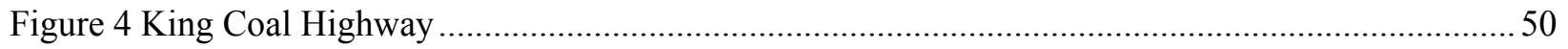

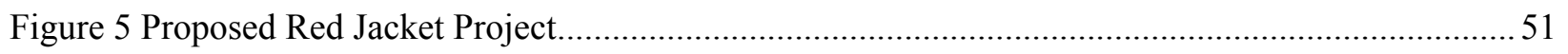

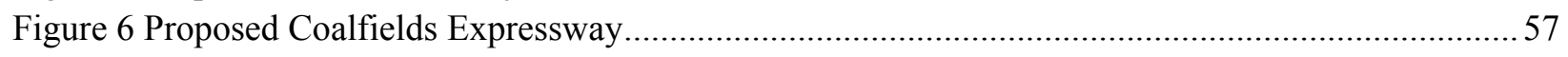

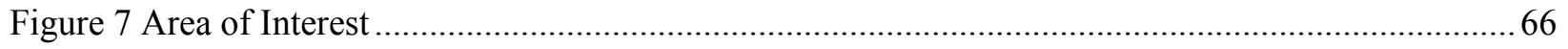

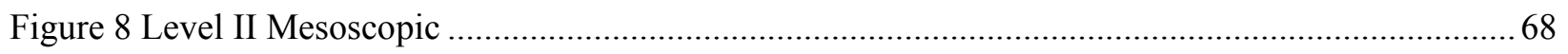

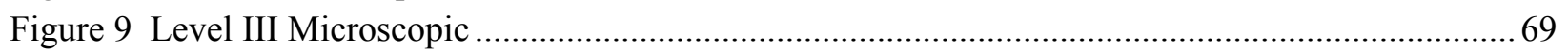

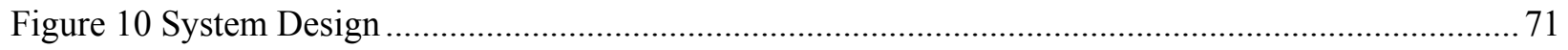

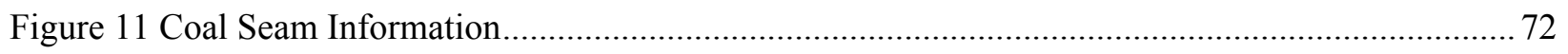

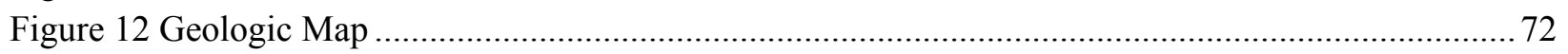

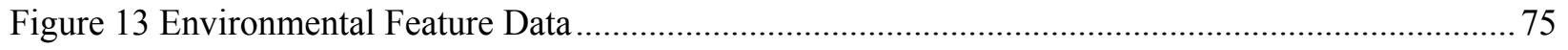

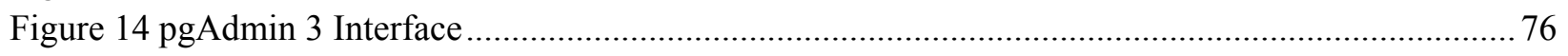

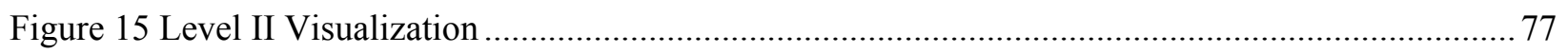

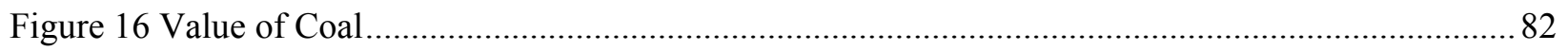

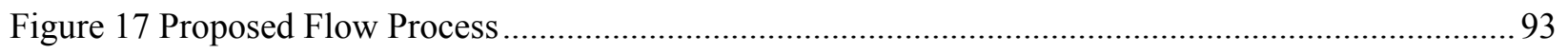

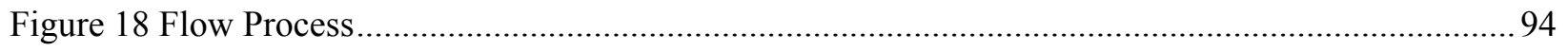

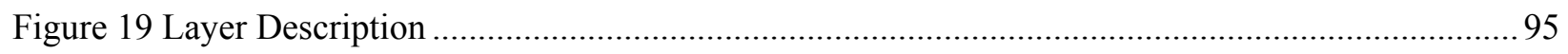

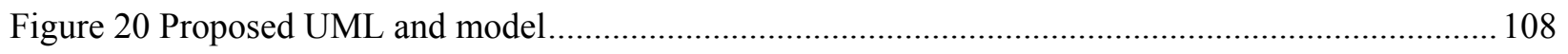

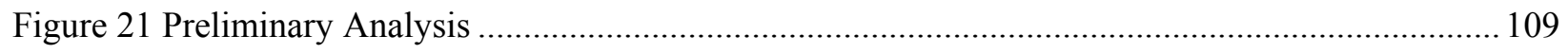

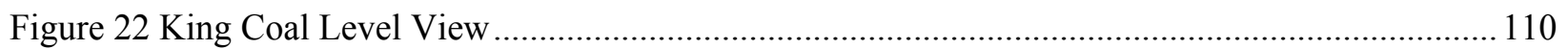

\section{List of Tables}

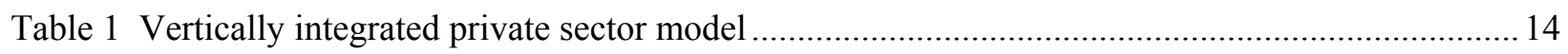

Table 2 State of Practice of Transportation PPP in United States ......................................................... 16

Table 3 Common Transportation PPP Types currently used in the United States.................................... 17

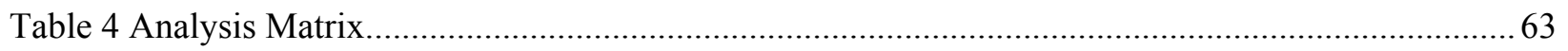

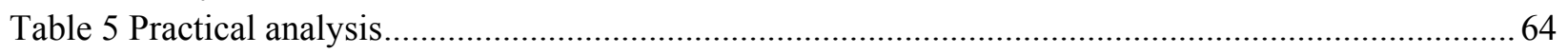

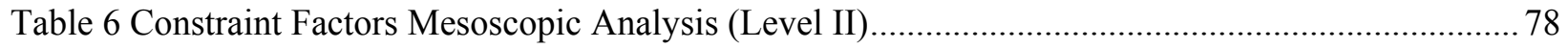

Table 7 Constraint Factors Microscopic Analysis (Level III) ................................................................ 79

Table 8 Macroscopic, Mesoscopic, and Microscopic Volumetric Analyses ........................................... 80

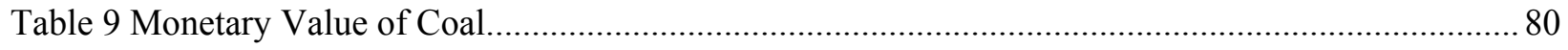

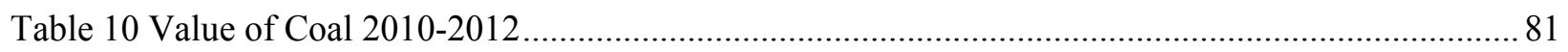

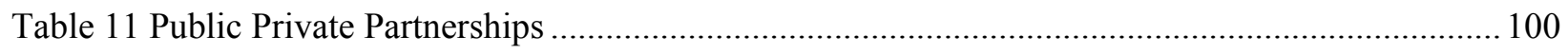

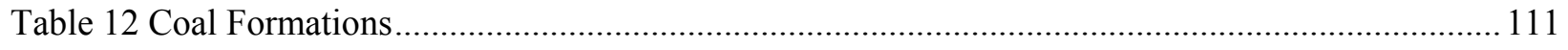

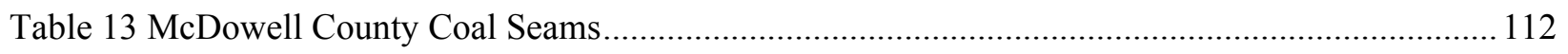




\section{Chapter 1}

\section{Introduction}

The days of big transportation expenditures under traditional funding are over. Resources for maintenance and expansion of existing infrastructure, such as the Housing Trust Fund (HTF), are fading. Historically, the HTF has been financially supported by the fuel tax, with almost 90 percent of the financing funded by gas taxes (National Surface Transportation Policy and Revenue Study Commission, 2008). More gas efficient vehicles and the increase of construction cost are causing the HTF to decline, especially in the highway account. The latest numbers indicate that if the gas tax is not increased by 5-8 cents per gallon, the HTF will have a negative balance in the next couple of years (National Surface Transportation Policy and Revenue Study Commission, 2008). This research proposes a possible solution to this funding dilemma through the implementation of a barter Public Private Partnership (PPP) that includes natural resources for trade model.

\section{Overview}

The current nationwide situation of deteriorating highway systems regarding the transportation infrastructure is due to the increase of public demand of services that federal, state and county governments cannot provide (Akintola, Beck, \& Hardcastle, 2003). As an example provided by

Poole and Samuel in the Public Roads article (Poole \& Samuel, 2006), the federal gas tax contribution to infrastructure is declining because taxes are not indexed for inflation and cars are now more energy efficient. Data indicates that the adjusted value of the federal plus state gas taxes produces between 2 to 3 cents per mile for vehicles (Poole \& Samuel, 2006). The 2008 
National Surface Transportation Policy and Revenue Study Commission Report determined that the United States needs to invest at least $\$ 225$ billion annually for the next 50 years to upgrade existing transportation networks and to invest in more advanced transportation systems. The Commission maintained that the present spending is less than 40 percent of the amount of money needed to upgrade the existing infrastructure. Essentially, the current fuel-tax based revenue mechanisms cannot support the existing transportation infrastructure (National Surface Transportation Policy and Revenue Study Commission, 2008).

Cartlidge (2006) examined Public Private Partnerships (PPPs) as potential alternatives to procure funds to advance the United States highway system. As indicated by Cartlidge in Public Private Partnerships in Construction (2006), the frameworks for PPP agreements are increasingly used to acquire goods and services. The author further noted that these frameworks have also been used for contracting the procurement of goods and services. According to Cartlidge, one of the main benefits of the PPP approach is the flexibility in adapting new project structures and being able to create a sui generis or unique approach for the development of the specific problemsolution.

Federal law permits the extraction of coal as a byproduct of the construction process, which under normal circumstances would not be economically feasible to extract. According to the Code of Federal Regulations 30, Mineral Resources (30 CFR § 213.5) (National Archives and Records Administration, 2009):

Extraction of coal as an incidental part means the extraction of coal which is necessary to enable the construction to be accomplished. For the purposes of this 
part, only that coal extracted from within the right-of-way, in the case of a road, railroad, utility line or other such construction, or within the boundaries of the area directly affected by other types of government-financed construction, may be considered incidental to that construction. Extraction of coal outside the right-ofway or boundary of the area directly affected by the construction shall be subject to the requirements of the Act and this chapter.

West Virginia law also permits Public Private Partnerships (PPPs) that allow the extraction of coal by surface mining to develop roadbeds for new highways (West Virginia Legislature, 2010). West Virginia Code $\S 17-28-3$ states that coal companies are not required to return the ground surface to its approximate original contour, which is typical for surface mining. Instead, companies agree to build the roadbeds for a new highway at the approximate elevation and grade as specified by the construction plans (M. Castle, Personal Comunication, October 28, 2011). There is no exchange of funds between the coal company and the Federal Highway Administration (FHWA) or the West Virginia Department of Transportation (WVDOT). The benefits are derived in the construction cost savings for roadbed construction (Castle, 2011, and D. Cramer, Personal Communication, May 12, 2011). Underground coal resources are proposed (Castle, 2011) to offset highway construction costs in locations where coal exists and is extractable. This process would require a public private partnership to be created among the FHWA, the WVDOT and the coal companies. 


\section{Statement of the Problem}

Agencies continually struggle to identify and allocate funding for roadway construction costs, particularly those along new alignments (U.S. Departament of Transportation Federal Highway Administration, 2010). Papers describing possible solutions for funding roadway construction costs (West Virginia Department of Transportation, Division of Highways, 1994 and Rahall Transportation Institute and Center for Business and Economic Research, 2011) determined that there is an opportunity to leverage the value of extracting natural resources along new roadway alignments to offset the construction costs. However, there is no existing methodology or spatial workflow model that allows the analysis of natural resources (e.g., coal and timber) reservoir location and quality (e.g., coal grade as lignite, bituminous and anthracite) for this purpose.

This research will develop a methodology that can be used to quantify the availability of natural resources, particularly coal, along predetermined roadway alignments. This will enable the inclusion of natural resource extraction in the current process used to select the preferred roadway alignment. Specifically, a geospatial analysis tool will be developed that combines subsurface coal seam information with the predetermined roadway alignment data along with the existing topography and landscape information. The geospatial framework uses location based information publically available and integrates with existing USDOT infrastructure. This study will complement and integrate procedures that are currently utilized with project development and highway alignment processes. 


\section{Justification for the Study}

In recent years, the traditional way of constructing roads has been under scrutiny (Queiroz, 2005 and U.S. Departament of Transportation, 2004). The partnership between Federal and State agencies is being reviewed for the inclusion of the private sector as a third partner (U.S. Departament of Transportation, 2004). According to Mallett (2008), the contribution of private money will involve low risk participation at a minimal cost, but will secure profit for the private organizations. The significance of the private sector being considered for inclusion in the highway framework is important because the United States Federal Government has not been able to maintain and plan for the growth of an aging transportation network (Mallett, 2008). This geospatial research is based on available public data, or low cost data to create an independent methodology to evaluate coal for highway construction. 


\section{Chapter 2}

\section{Literature Review}

Chapter 2 is a review of literature germane to this study: Geospatial Framework for the Use of Natural Resource Extraction in Public Private Partnerships. More specifically, this chapter investigates literature relative to the variables of Public Private Partnerships (PPPs), geospatial transportation system development, and the phases of the roadway project development.

\section{Public Private Partnerships}

As stated by Victor Mendez, Arizona Department of Transportation (DOT) Director and American Association of State Highway and Transportation Officials (AASHTO) Vice President, at the Portland Field Hearing of the National Surface Transportation Policy and Revenue Study Commission in 2006, "While tolls currently contribute about 4.5 percent of transportation funding nationwide, under the most optimistic scenario AASHTO envisions, tolls could reach only 9 percent of total revenue." (National Surface Transportation Policy and Revenue Study Commission, 2006).

Other experts (Li, Edwards, \& Hardcastle, 2005; Mallet, 2008) expressed concern regarding methods of financing the nation's highway structure and suggested possible avenues for funding. Former United States Transportation Secretary Norman Y. Minieta stated in an interview with Rebecca Roberts from Public Broadcasting Services (PBS): 
Well, I think, given the fact that there are just limited financial resources all the way around, I think the need for public-private partnerships is going to grow much more in the future. When you think about the amount of money that goes into research and development on specific transportation modes or when you think about the long time line it takes in terms of trying to build infrastructure and especially where we're trying to -- to lessen the gap between the demand for transportation and the ability of our transportation infrastructure to supply that demand, that it really requires public-private partnerships both in money, thought, and effort. (Norman Mineta former U.S. Transportation Secretary, n.d.).

To accommodate the demand for infrastructure, local and state governments are looking for new funding sources for building or maintaining new projects (Miller J. B., 2000). As a result, private financing has an increasingly important role in infrastructure development. On the other hand, many private interests want to obtain government sponsorships and tax reductions through association with public sector in long term partnerships (Li, Edwards, \& Hardcastle, 2005).

One constant component in the literature (Akintola et al., 2003) is the recognition that increased private participation and more innovative funding methods are needed to reduce the backlog of infrastructure projects and to confront future requirements. The Federal Highway Commission (n.d.) reported that substandard road conditions are unsafe. The Commission's report indicated that outdated and substandard road and bridge design, pavement conditions, and safety features are factors in 30 percent of all fatal highway accidents. Therefore, the Federal Highway 
Administration (ASCE, n.d.) attributed 30 percent of fatal highway accidents to unsafe, outdated, and substandard road conditions.

\section{Definition of Public Private Partnerships}

Public Private Partnerships (PPPs) can be defined as a flexible legal framework with a stable macro-economic environment that facilitates the development of long term agreements among different groups such as banks, investment funds and governments (Akintola et al., 2003).

The willingness of the public sector to carry a substantial part of a contract (up to $40-60$ percent of total project cost in some cases) has been an important factor in successful public private collaboration (Akintola et al., 2003). Public sector support may also include the provision of an in-kind contribution of existing assets and other assistance (Akintola et al., 2003). A traffic count of 10,000 vehicles per day needs to be demonstrated for it to be feasible to build a new toll road (World Bank, 2001). However, if the government offers a subsidy to the private sector, a different rate would need to be calculated which would be in agreement with the public sector. For example, the rehabilitation of a road, particularly where there are no competing corridors, can be viable where the flow is as low as 6,000 vehicles per day (World Bank, 2001).

In applying this definition to a West Virginia highway development proposal, the King Coal Highway, Dr. Clifford Winston (C. Winston, Personal Communication, May 5, 2011) from the Brookings Institution stated, "The proper way to assess the King Coal Highway $(\mathrm{KCH})$ project is to compare the annualized value of the public and private expenditures on the road with the annualized value of the aggregate travel time savings." The proposed King Coal Highway will 
extend through five counties in West Virginia-Logan, Mercer, Mingo, McDowell and Wyoming (Federal Highway Administration, n.d.; West Virginia Departament of Transportation, 2000). This highway (National I-73/74/75 Corridor Association) system is a portion of the National I73/I-74/I-75 Corridor which originates at the United States Canadian border and extends to Myrtle Beach, South Carolina. Dr. Winston's assessment of the King Coal Highway proposed project is consistent with the three basic questions posed by Queiroz (2005) for a robust economic and financial appraisal of the project. These questions include:

1. Is the project beneficial for society?

2. Is it commercially viable for the potential concessionaire?

3. Is the required public sector contribution justified in terms of the additional benefits engendered by that contribution? (Queiroz, 2005).

\section{Categories Public Private Partnership}

The National Cooperative Highway Research Program (NCHRP) Synthesis 391 Public Sector Decision Making for Public-Private Partnerships (2009) divides Public Private Partnerships (PPPs) into three major categories for the decision making component.

1. Project selection and delivery. The selection and delivery category for decision making involves: a) Project accomplished by a PPP approach; b) Stakeholder's expectations and risk allocation defined; c) Financial viability of the project d) Types of financial sources available; and e) Return on the Investment.

2. Transparency. Transparency is a critical category for PPP decisions for public, local, state, and national considerations. This category includes: a) Public contribution and b) Approval from the legislative branch of the government. 
3. Terms of Agreement. The final category results in application of Category 1 and Category 2. Terms of Agreement involve: a) Time frame for the partnership; b) Maintenance; c) Policies regarding tolling and revenue allocation; d) Legal issues such as labor, safety and law enforcement; and e) Commercial development rights.

All of the above categories of decision making regarding Public Private Partnerships (PPPs) are important because there is a common perception that PPPs are a type of privatization of the sector. As stated in the Synthesis 391 (2009), the lack of structure in selection of a PPP is a concern. Transparency is another important issue in the project PPP selection because transparency builds credibility to the highway project. According to Miller (2000), there is a sense that public PPPs are a type of privatization; therefore, it is essential for proposals aimed at developing a highway system to consider the three categories in PPP.

\section{Advantages of Public Private Partnerships (PPPs)}

Synthesis 391 (2009) identifies the following advantages of PPPs: a) Fostering innovation: b) Open competition; and c) Collaboration among different sectors. The rationale of fostering innovation for PPPs is not often used in the development of the contracts.

\section{Disadvantages of Public Private Partnerships (PPPs)}

Synthesis 391 (2009) identifies the following disadvantages of PPPs: a) One persistent goal for using PPPs is to gain value. The main question is the metrics for gain or losses and b) Procurement is an often underestimated process. Because the lack of transparency has an 
important influence in the public perception of the process, the contract needs to have credibility for the sake of the process and for the perception of the public.

A common, though not essential, element to greater private sector participation in highway infrastructure provision is the use of tolling. Vehicle tolls provide a revenue stream to retire bonds issued to finance a project and to provide a return on investment (Daniels \& Trebilcock, 1996). The authors indicated that Public Private Partnerships (PPPs) gain from applying private sector best practices, such as vertical integration infrastructure.

Table 1 illustrates the typical vertical integration for Public Private Partnerships (PPPs). Such an approach is also used in the PPP deployment in the transportation industry. Daniels and Trebilcock (1996) presented four steps in the vertically integrated private sector model. The first step is the identification of the project. Step two involves the project design phase. The third step consists of financing relative to the design followed by construction. Operation and maintenance compose the fourth step in the vertically integrated private sector model.

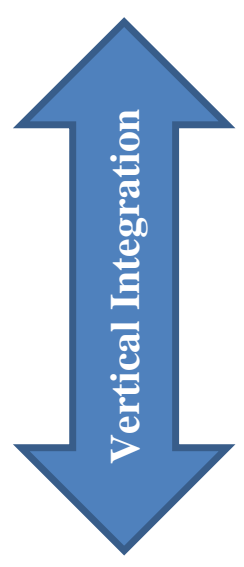

Project identification

Design

Financing, design, and construction

Operation and maintenance

Table 1 Vertically integrated private sector model 
Miller (2000) indicated that this type of agreement between the public and private sector is not new to the federal government. He noted that in the early 1790s, Congress promoted the development of postal roads in rural areas in exchange for postal revenues. These agreements were bartering arrangements between the federal government and citizens who were willing to build and maintain small roads in exchange for the commitment of the federal government to move the mail over such roads and share the postage fees with the builders. These agreements have continued through the 1790s up to the twentieth century (Miller, 2000).

Congress (1803) has also approved numerous types of exchanges, from land in exchange for infrastructure, such in the case of the Charleston (Massachusetts) Navy Yard. In this specific case, Congress sold the yard to the proprietors of the Salem Turnpike and Chelsea Corporation on the condition that the land would be used to connect Salem Turnpike with the Chelsea Bridge by a toll turnpike (Congress, 1803). These basic exchanges evolved into the federal government entering into more complex agreements as the nation moved forward (Miller, 2000). Miller (2000) discussed one of the federal governments' more complex agreements, which involved the 1836 agreement with New Orleans and Nashville Railroad Company over the $80 \mathrm{ft}$. wide rightof-way of a public land. The right-of-way was contingent upon approval of the route by the Secretary of War prior to the construction. Under the agreement, the railroad companies had the right to use the earth, stone, wood and other materials on the public lands along the railroad tracks. All of these perks were allowed with the conditions that the company begin the construction two years later and finish the construction in eight years (Miller, 2000). The literature indicates that public participants may or may not have a monetary transaction (Miller, 2000). According to Miller (2000), the benefits of the transaction may or may not 
appear to affect the public sector. In the case of this research, the government runs the risk that the local area will not be developed as planned. The coal extraction permits can be used in a new and innovate alternative way. If the action plan works according to the original idea, the rewards of having surface coal extraction will bring economic development and benefits to one of the most economically depressed areas in southern West Virginia. The risk and rewards concept is straight forward.

Table 2 reviews the Public Private Partnership (PPP) practices in the United States as of August 2011 (Papajohn, Cui,\& Bayraktar, 2001). The authors generated an extensive overview of the usages of PPPs in the United States. West Virginia is one of 14 states that will implement PPPs in the near future (Papajohn, Cui, \& Bayraktar, 2011).

\section{State of Practice of Transportation PPP in United States}

\begin{tabular}{|c|c|c|}
\hline $\begin{array}{l}\text { State of } \\
\text { Practice }\end{array}$ & State & $\begin{array}{l}\text { Percent of responding } \\
\text { states }\end{array}$ \\
\hline Experienced & $\begin{array}{l}\text { California, Connecticut, Florida, Minnesota, } \\
\text { South Carolina, Texas, Virginia }\end{array}$ & 22 \\
\hline $\begin{array}{l}\text { Currently } \\
\text { practicing }\end{array}$ & Colorado, Nevada, Washington & 9 \\
\hline $\begin{array}{l}\text { Plans to } \\
\text { implement }\end{array}$ & $\begin{array}{l}\text { Arizona, Illinois, Kansas, Kentucky, } \\
\text { Louisiana, Michigan, Missouri, Mississippi, } \\
\text { North Carolina, New York, Pennsylvania, } \\
\text { Tennessee, Vermont, West Virginia }\end{array}$ & 47 \\
\hline $\begin{array}{l}\text { Does not plan } \\
\text { to implement }\end{array}$ & $\begin{array}{l}\text { Montana, North Dakota, Oregon, South } \\
\text { Dakota, Utah, Wisconsin, Wyoming }\end{array}$ & 22 \\
\hline $\begin{array}{l}\text { Did not } \\
\text { respond }\end{array}$ & $\begin{array}{l}\text { Alabama, Alaska, Arkansas, Delaware, } \\
\text { Georgia, Hawaii, Iowa, Indiana, } \\
\text { Massachusetts, Maryland, Maine, Nebraska, } \\
\text { New Hampshire, New Jersey, New Mexico, } \\
\text { Ohio, Oklahoma, Rhode Island }\end{array}$ & N.A. \\
\hline
\end{tabular}


Table 3 exhibits the type of Public Private Partnerships (PPP) that will be in place in different states across the United States. For the purpose of this research, West Virginia plans to implement a Design Build Finance and Operate highway construction PPP (Papajohn, Cui, \& Bayraktar, 2011).

\begin{tabular}{|ll|}
\hline $\begin{array}{l}\text { Type of PPP } \\
\text { Predevelopment } \\
\text { agreements }\end{array}$ & $\begin{array}{l}\text { States using PPP Type } \\
\text { Virginia }\end{array}$ \\
\hline $\begin{array}{l}\text { Long-Term lease } \\
\text { agreements }\end{array}$ & California, Colorado, Texas, Virginia \\
\hline $\begin{array}{l}\text { Design-Build-Finance- } \\
\text { Operate }\end{array}$ & Florida, North Carolina, Texas, Virginia, West Virginia \\
\hline
\end{tabular}

Papajohn, Cui, \& Bayraktar 2011

Table 3 Common Transportation PPP Types currently used in the United States

\section{Geospatial Transportation System Development}

\section{Background}

Ronald N. Buliung (2005) traced the usage of primitive computer models for transportation and land management to the 1950 s and reported that computer models had the capability of more realistic applications in the 1960 s. During that period, the military and other mapping agencies started the endless journey of digitization with more automated techniques and with the help of newer technologies (Vemez, 2000). In the 1970s, lower prices for improved technologies made hardware more accessible and more affordable allowing new geospatial applications. Some critiques and disappointments were the result of the applications in the 1970s and 1980s (Landis \& Zhang, 2000). As stated by Miller (2001) and Buliung (2005), the early deployments of integrated urban models and geospatial modeling in transportation were independent from one 
another. The real potential exploration was not until the mid-1990s, which was primarily prompted and newly introduced by the United States Environmental Protection Agency Clean Air Act Amendments of 1991 (Miller, 2001). This Act required cities to consider land use, transportation interaction and impacts in a consistent and integrated fashion before deciding on improvements in transportation infrastructure.

The cognitive issues touch on all three major functions of geospatial modeling: storage, representation, and analysis of earth-referenced data (Goodchild 1992). It explains geospatial information such as the Where and the What at that location. Geospatial systems are concerned with processes in utilization of the information referenced to the Earth's surface. The development of geographic information systems ushered in a revolution in geospatial data representation, collection, storage, management, analysis and modeling. Binding together location, attribute data and geographic information systems provides a powerful environment within which to measure geospatial identities, explore spatial relationships, and ultimately model spatial processes.

Vernez (2000) discussed how new computer technologies allow data collection and analysis as an option that may be considered in the use of image based maps. Vernez (2000) further explained that in the application of using image based maps and geodatabases, these technologies are common practice in the land information systems. Therefore, there are areas in which the linking of spatial models and geographic information systems can provide new insights and places where new ideas and new models are being developed. Landis and Zhang (2000) 
identified four areas where developments are an important key component of the analysis. These areas include: data capture, data organization, data visualization, and spatial analysis.

Data capture is extremely important because it can be accountable for 15-50 percent of the total implementation cost or more depending upon the budgeting of the time spent by staff (Longley, Goodchild, Maguire, \& Rhind, 2005). These authors contend that data organization is a complex and an expensive long term commitment. Goodchild et al. (2005) explained this is because of the huge amount of data that needs to be kept and maintained, such as changes in land parcel ownership, mineral properties or linear reference updates for the transportation networks. Data visualization demonstrates the relationships among the different data sources. Spatial analysis is the integration of data in a form suited to geographic information systems and is key to the spatial analysis because of the relationship between data and geographic information (Fotheringham, 2001; Fotheringham, Brunsdon, \& Charlton, 2002).

\section{Regional Analysis and Modeling}

Regional economic impacts generally fall into two categories, predictive or ex ante and evaluative or ex post (Transportation Research Board, 1998). The first, predictive, is the analysis of economic impact after the completion of a highway. Predictive studies are based on actual data collected through surveys or interviews. Some predictive studies compare economic indicators before and after the highway construction (Transportation Research Board, 1998). Other studies, evaluative or ex post, choose a similar region without highway construction as a control and analyze the difference between the two regions. The evaluative type of analysis utilizes forecasting. Simulation models are used to estimate the potential weight of a highway 
based on hypothesis and projections. Studies based on post-constructions data are important as they provide important hypothesis modifications (Mitchem, 2009).

\section{Spatial Analysis and Modeling}

Spatial analysis and modeling improve the richness and accuracy of regression models (Landis \& Zhang, 2000). Spatial modeling offers urban modelers a data structure and data set manipulation tools though which they can explore the spatial process inherent in urban activities. This research will explain spatial processes, and how can they be measured. Haining (1990) and Fotheringham and Wegner (2000) have identified four types of spatial processes that arise in urban activities.

1. Spatial Diffusion and Dispersal. These occur when one or more attributes spread gradually over space, usually affecting nearby agents first. This type of "spreading out" dynamic is common to many urban processes, including, for example metropolitan job and population growth, neighborhood succession and master use land plan (Haining, 1990; Fotheringham \& Wegner, 2000).

2. Exchange and Transfer. This process dominates many types of human activity, especially economic activity. Location may affect both production and consumption decisions. Prices may be spatially differentiated, reflecting differential transportation costs. The spatial proximity of competitors may enhance competition while a lack of nearby competition may reduce it (Haining, 1990; Fotheringham \& Wegner, 2000).

3. Interaction. Spatial interaction involves movement and/or communication over space. The nature of interaction is determined by the characteristics of the various sets of origins and 
destinations as well as by the spatial separation between the two sets. Through spatial interaction, activities at one location may be influenced by activities at the other distant location (Haining, 1990; Fotheringham \& Wegner, 2000).

4. Spatial Segmentation or Percolation. This process may occur when a homogeneous spatial entity separates into two or more parts of a qualitative different character. A variety of factors, such as agglomeration, division of labor, multiple equilibrium, and racial prejudice can give rise to spatial segmentation. Spatial segmentation can also result as a consequence to random or stochastic processes. The processes are not necessary mutually exclusive. They may occur simultaneously or even in opposition to each other (Haining, 1990; Fotheringham \& Wegner, 2000).

The four types of spatial processes (Spatial Diffusion and Dispersal, Exchange and Transfer, Interaction, and Spatial Segmentation or Percolation) give rise to traditional approaches of transportation analysis defined by Sussman (2005) that include: Qualitative model (simulation), Qualitative Framework Analysis, and Transportation Domain Knowledge.

Quantitative model (simulation). Quantitative impacts are measurable data for specific problems that can be processed and analyzed numerically. They vary from simulation, statistical, and econometric modeling to operational field test and case studies. The simulation process can be Macroscopic, Mesoscopic and Microscopic. From the theoretical point, these estimates are needed to be converted to money value, and used in the overall cost/benefit ratio. 
Qualitative Framework Analysis. Qualitative impacts are more difficult to estimate. These elements can be subdivided into: Qualitative Elements Qualitative Assessments. Qualitative Elements are elements related to aspects which can be measured, but not in a numerical way, for example hedonic values. Qualitative Assessments are used when some aspects cannot be measured due to limitations such as time frame. A quantitative assessment is sometimes all one can achieve. According to Sussman (2005), these assessments can provide realistic estimates of anticipated impacts, especially when no other ways of assessments are possible.

Transportation Domain Knowledge. The transportation domain knowledge is the use of multi-agent scenarios (Fisher, 1993). Fisher (1993) explained that to model spatial processes, one must collect spatial data, or at least collect data that includes spatial attributes. He further cautions that traditional data collection and representation methods tend to obscure or distort the spatial nature of attributes. According to Fisher (1993), the practice of collecting socioeconomic data at an aggregated zonal level, for example, treats all events within a particular zone as spatially homogeneous. This tends to minimize intra-zonal effects. Fisher (1993) further explains that the representation of data in two-dimensional tables or matrices, another common practice in urban modeling, often requires the casting aside of spatial characteristics. Once lost, such characterization is difficult to reestablish. Advances in geospatial systems representation provide a technical basis for overcoming some of these difficulties, but to take full advantage of the richness of spatial information represented in geospatial models, geographers and modelers must rethink how they extract spatial measurements from maps and other sources of spatial information (J. Brumfield, Ph.D., Personal Communication, February 3, 2011.) 
The core component of any geospatial application or tool is the integration of spatial framework which capability is often underutilized (Larsen, 1999). Longley (2005) addresses how these tools or models can break down the representation or model to provide details about the research area (Longley, Goodchild, Maguire, \& Rhind, 2005). The ability to display and aggregate data from different sources is a very important component in the decision support process (Larsen, 1999). According to Longley (2005), models or geospatial tools can have the following limitations (pp 380-381):

- A model may reflect behavior under ideal circumstances and therefore provide a norm against which to compare reality.

- A model should not be measured by how closely its results match but how much it reduces uncertainty about the future. If a model can narrow the options, then is useful. It follows any forecast should be accompanied by realistic measure of uncertainty.

- A model is a mechanism for assembly of knowledge from a range of sources and presenting conclusions based on that knowledge in a readily usable form. It is often not so much a way of discovering how the world works, as a way of presenting existing knowledge in a form helpful to decision makers.

- Modeling often offers the only robust, transparent analytical framework that is likely to garner any respect among decision makers with competing objectives and interest.

Geospatial models represent real world processes (Longley, Goodchild, Maguire, \& Rhind, 2005). These models take advantage of the data collection and analysis of spatial data. A 
Geographic Information System (GIS) is used to compile and organize data and/or display data in a model (Wilson, 1999).

\section{Roadway Project Development}

\section{Project Development Process}

Major transportation projects have six well defined stages: Planning, design, construction, operations, maintenance and financing (Beard, Loulakis, \& Wondram, 2001). For the scope of this research, the researcher analyzed the first three stages (planning, design, and construction) in their role in transportation projects.

Planning is a process which generally involves the development of project objectives. This process usually includes identifying an appropriate road location; outlining a plan for construction; assessing technical and financial feasibility for the proposed construction. In terms of allocation of resources, the planning stage is inexpensive, but the outcome results have an important role in the future of the project (Beard et al., 2001).

The design phase addresses issues identified in the first stage (planning) such as constraints and parameters. In the design phase, the project changes from a conceptual idea to a more tangible final design (Beard et al., 2001).

Final Design is the final document used to place the contract for the bidding process. The planning phase evolves to the implementation phase of the construction stage (Beard et al., 2001). 


\section{Cost Estimating}

The purpose of estimating cost is to develop a financial projection for cash analysis, not to produce exact data about the future, which is impossible (Sullivan, Wicks, \& Luxhoj, 2005). Sullivan, et al., (2005) explained that engineering economic analysis focuses on the consequences of current decisions for the future. The authors determined that estimating is the foundation of economic analysis. As is the case in any analysis procedure, the outcome is only as good as the quality of numbers used to reach the decision (Beard et al., 2001).

The estimates can be defined in three general types among which purposes, accuracies, and underlying methods are quite different. The three cost estimate types include: Rough Estimates (Macroscopic Analysis), Semi-Detailed Estimates (Mesoscopic Analysis), and Detailed Estimates (Microscopic Analysis), (Newman, Lavelle, \& Eschenbach, 2002).

The rough estimates (macroscopic analysis) are used in planning to produce estimates used for high-level preparation, macro-feasibility, and in a project's initial planning and evaluation phases. Rough estimates tend to involve back-of-the-envelope numbers with little detail or accuracy. The intent is to quantify and consider the order of the numbers involved. These estimates require minimum resources to develop, and their accuracy is generally -30 to 60 percent (Newman et al., 2002).

The semi-detailed estimates are compiled to support projects in the conceptual or preliminary design stages. Semi-detailed estimates require additional time and resources to develop; therefore, these estimates are more detailed. Greater sophistication is used in developing semi- 
detailed estimates than the rough-order type, and, their accuracy is generally -15 to \pm 20 percent (Newman et al., 2002).

Detailed estimates are used during a project's detailed design and contract bidding phases. Made from detailed quantitative models, blueprints, products specification sheets, and vendor quotes, detailed estimates involve the most time and resources to develop. Consequently, they are much more accurate than rough or semi-detailed estimates. The accuracy of these estimates is generally -3 to +5 percent. The American Association of Cost Engineering classes a definitive estimate at 80 percent design level as being with -5 and +15 percent of the final project cost, barring further scope change (Beard et al., 2001).

When considering the three types of estimates, it is important to recognize that each type is unique in purpose, place, and faction in a project's life. Level I (Macroscopic) rough estimates are used for general feasibility activities; Level II (Mesoscopic) semi-detailed estimates support budgeting and preliminary design decisions, and Level III (Microscopic) detailed estimates are used for establishing design details and contracts. As one moves from rough to detailed design, one moves from less to much more accurate estimates (Beard et al., 2001).

The progression from Level I to Level III involves more time and resources to increase accuracy of estimates. However, regardless of how accurate an estimate is assumed to be, it is still simply an estimate. Some error will be implied regardless of resources and sophisticated methods that are used (Beard et al., 2001). 
Often the main objective in developing a highway system is to develop an infrastructure with cost savings. Undertaken during the statement of a need phase of the project, the feasibility estimate enables the owner to make cost/benefit comparisons in the absence of extensive project data (Beard et al., 2001). Capital expenditure and project selection decisions are based on knowledge of investments objectives, funding inflows and outflows, design/economic life of the facility, and investment risk. Related capital budgeting analysis is able to synthesize the data to form a reasonably accurate feasibility estimate (Beard et al., 2001).

\section{State and Federal Regulatory Guidelines}

A Federal highway project is a long and difficult enterprise (D. Cramer, Personal

Communication, May 12, 2011). It starts with a concept and ends with the construction of the project including engineering, design, environmental and economic concepts (D. Cramer, Personal Communication, May 12, 2011). Environmental documentation includes the development of an environmental impact statement, environmental assessment, or categorical exclusion. The environmental documentation is based on the scope, characteristics, location and initial engineering information of the project. This effort will vary from project to project and may involve outside agencies, individuals, and special interest groups. Early coordination with regulatory and resource agencies is required in order to expedite the resolution of issues. The environmental document must meet the requirements of the National Environmental Policy Act, Council of Environmental Quality Regulations, Federal Highway Administration guidance, Section 404 of the Clean Water Act, Section 106 of the National Historic Preservation Act, Section 4(f) of the Department of Transportation Act, Endangered Species Act, and other environmental and cultural resource concerns (West Virginia Departament of Transportation, 
2006). The Environmental Impact Assessment (EIA) is derived from the surrounding environment, which can be represented by a geospatial model. This model can help in the development of the assessment. Currently, the objectives of the project are dictated on a caseby-case analysis; there are no rules per se as to how to conduct an environmental assessment (ElGafy, 2005).

The final environmental impact statement from the federal government mainly addresses the qualitative impacts of the assessments (West Virginia Departament of Transportation, 2006). The extent to which the anticipated development may shift involves establishing criteria and weighing each according to its likely importance to influence the best decision regarding locations. The future land trends are an important part of the analysis. The possible modifications of the usage of the land around the project can be modeled with the use of remote sensing and imagery.

\section{West Virginia Department of Transportation Project Development Process}

West Virginia has three main phases of project development for new roadway construction projects - Initial Engineering, Preliminary Engineering, and Final Design (ref design directive). During the Initial Engineering phase, multiple roadway corridor alternatives are evaluated using various metrics and a preferred corridor is selected. During the Preliminary Engineering phase, the specific roadway alignment within the preferred corridor is determined (D. Cramer, Personal Communication, May 12, 2011). During the Final Design phase, the actual construction plans are prepared. 
West Virginia Department of Highways (2010) Design Directive \#202 that defines the Initial and Preliminary Engineering and Design Directive \#706 that defines the Final Design specifically state (West Virginia Departament of Highways, 2010):

Initial engineering is that work which is performed to define major project features. The design includes features such as location, profile, geometrics major drainage features, geotechnical studies, identification of preliminary right of ways and the analysis of several alternatives.

Preliminary engineering is that work which is performed to further refine the preferred alternate identified during the environmental documentation phase. This work includes roadway geometrics, structural requirements, drainage, erosion control, geotechnical issues, earthwork, traffic control, safety, value engineering, and environmental and cultural resource avoidance or mitigation. Included in this phase is preliminary field review and senior engineering review, geotechnical (slope) review, bridge type, size and location plans span arrangement submissions (to include pre-span arrangement submissions) and preliminary right of way plans (RW-2) necessary to identify property owners, utility verifications, and to start property abstracting.

Final design is that engineering necessary to complete construction contract plans and related documents, prepare specifications, proposals, and cost estimates. This work includes plans and other documents that will be included in the bidding process, such as the final field review; type, size and location approval; final 
office review; final bridge plans; final right of way plans; and utility relocation designs necessary for the acquisition of right of way.

The current project development process in West Virginia only considers coal in the right-ofway (ROW) acquisition process (D. Cramer, Personal Communication, April 4, 2012). According to Cramer (2012), West Virginia also attempts to avoid highway project development in areas where coal is available. He indicated that the main reason that the common practice of avoiding areas where coal is available is because acquisition costs can become extremely high, such as in the case of the existence of mineral rights during the appraisal process. West Virginia Department of Transportation (WVDOT) has to pay a fair market value of the mineral rights which results in a considerable increase in the overall cost of the project.

The mountainous terrain of West Virginia makes highway construction difficult (B. Car, Personal Communication, April 12, 2012). The biggest part of the highway construction cost is the cut and fill process necessary when the roadbed has to meet curve and grade standards. For example, new 4-lane highways constructed in the southern coal fields could easily be $\$ 25$ - $\$ 30$ million/per mile, while in the eastern panhandle the cost might only be $\$ 15-\$ 20$ million per mile due to the terrain type and the amount of earthwork involved (D. Cramer, Personal Communication, April 4, 2012). Another extremely important factor for consideration is the environment. The only source of reliable information is the institutional knowledge of the engineers and how sensitive the environmental factors are in the Area of Interest (AoI). During the researcher's personal communication with West Virginia Department of Transportation (WVDOT) engineers, the engineers stated that if coal was going to be a consideration to offset the construction costs, it should be considered at the beginning of the project development 
process at the Preliminary Engineering stage. In the overall project development, these estimates are typically followed by an environmental review and the development of a design report, after which the project design starts (D. Cramer, Personal Communication, May 12, 2011).

\section{Preliminary Engineering}

Preliminary engineering is the development of a plan and budgetary components of specific projects when the development is taken from the planning to the design stage. The primary elements in a highway project cost can be divided in the following categories (Turochy, Hoel, \& Doty, 2001):

1. Preliminary Engineering (PE).

2. Right-of-Way and Utilities (RoW).

3. Construction Cost $(\mathrm{CN})$.

The authors further identified three general categories used in the planning stage of project development to estimate cost of the project. These include: 1 . Generic methods that uses tables of "cost-per-mile" values by typical highway section (e.g., rural four-lane divided); 2. Specific methods that involve estimations of "rough" quantities of all major items and incidentals on a project-specific basis; and 3. As the project goes (Turochy, Hoel, \& Doty, 2001).

According to Mr. Bill Woods (as seen in Turochy et al., 2001), West Virginia's processes for developing planning-stage cost estimates are not highly structure in that cost-per-mile and costper-incidental-item tables are updated annually. Cost-per-mile generally is determined from the cost estimates within the environmental document (different alternatives) and the total cost is divided by the length of the alternative/corridor to arrive at an average cost per mile. The 
parameters for each section are based in useable sections of the proposed corridor. These sections are based according to the topography of the area and connectivity of objects such as roads, cities or townships. Sections can vary in length and consequently the cost of the segment will vary. This methodology is reviewed about every three years (Turoch et al., 2001).

The cost-per-incidental item is the mean of each individual item used in the road/bridge construction such as Hot-Mix Asphalt (HMA), guardrail, base, subgrade, and concrete. These items are updated annually in the "Unit Bid Prices" and can be found online (West Virginia Departament of Transportation, 2012). The West Virginia Department of Transportation (WVDOT) uses these item costs as often as possible because they provide a better estimate especially if quantities are available or quantities are estimated.

Without hard or reasonable quantities of items and for quick estimates, per mile methodologies are used, but typically only on an "as needed" basis and are updated as needed areas (B. Car, Personal Communication, April 12, 2012). Car (2012) emphasized that when utilizing "permile" methodologies, special consideration should be given to terrain type, i.e., level, rolling, and, mountainous as well as location, i.e., urban, suburban, and rural. Car (2012) further indicated that historical data from similar projects recently completed near the proposed project are used if available; otherwise tables with cost- per-lane-mile are used. Furthermore, tables with generic estimates for bridges and incidental items are also available.

\section{Right of Way, Preliminary Engineering and as the project goes}

West Virginia Departament of Transportation (WDOT) calculates Right of Way (RoW) using percentages and usually includes utilities in the estimate. A site visit is often warranted on 
complex projects to examine the land involved and to determine if adjustments to the cost are necessary. In the absence of actual RoW/utility estimates (number of homes, businesses, parcels acquired and water, sewer, electric, phone, and cable), the WVDOT uses percentages based on the location - urban, suburban, or rural. These percentages are essentially derived from institutional knowledge of the estimator and knowledge of the Area of Interest (AoI). The percentages could be anywhere from 30-35 percent of the total construction cost for urban areas to as little as 5-10 percent in very rural areas (B. Car, Personal Communication, April 12, 2012).

Preliminary engineering is usually estimated to be 8 percent of the construction cost (Car, 2012). According to Car (2012), planning capital cost estimates are revised periodically during the design process and when the project is bid for construction. An update is also done as more data are available and during the construction phase.

Regarding the phase, as the project goes, there is no indication that this method is widely used at the West Virginia Department of Transportation (Car, 2012).

According to the West Virginia Department of Transportation (WVDOT), highway cost varies significantly. The following factors have an impact on the final cost of a highway construction project: Length, Pavement Type, Width, Clearing and Grubbing, Earthwork, Drainage, Structures, Maintenance, Retaining/Sound Walls, Number of Intersections, Number of Lanes, Seeding, Lighting, Signalization, Guardrails, Signage, Contingencies, Right-of-Way, Inflation, Preliminary Engineering, Bridges, and Urban vs. Rural. 
Time constraints are also considered in a project development (National Surface Transportation Policy and Revenue Study Commission, 2008). All the stakeholders work concurrently to avoid delays and redoing processes in each stage. If a decision requires the possibility of natural resource extraction, the planning stage is the proper time for the West Virginia Department of Transportation (WVDOT) and private companies to work simultaneously. Each year that passes from the decision to build a highway project until conpletition, the overall increment in cost is five percent (Flyvbjerg, Skamris Holm, \& Buhl, 2004). Therefore time is an important factor to take into consideration (Flyvberg et al., 2004).

Findings by Sturm (2011) suggest that many projects are not updated even if a reasonable period of time elapses. The time between the phases can improve accuracy of the cost estimate. Sturm's research showed the majority of highway construction projects have experienced cost increases. However, Sturm (2011) reported that further research is needed because only 30 percent of the 70 projects he reviewed had cost associated in all the different phases. Sturm's findings regarding data accessability or estimates are important because data were not included in the documents to properly compare all estimates. The researcher concluded that data accessibility is important for further research.

The West Virginia Department of Highways (WVDOT) does not have a table for cost or a formal estimation process (B. Car, Personal Communication, May 10, 2012). If a project has been approved, the design process will assess a rough estimate and as the development moves forward, the estimates become more accurate. Car (2012) explained that estimates are undertaken in cases where the project does not have a design and the qualities are unknown. 
This early assessment is used for the planning stages of funding. The cost estimate is developed as the project evolves into construction and the project cost is reviewed to allow the release of necessary funds for the beginning of the construction (B. Car, Personal Communication, May 10, 2012).

\section{Environmental Impact Study Process}

A major aspect of the Initial Engineering phase is the environmental impact study (EIS) process which quantifies the impacts of each alternative to aide in selecting the preferred alternative. The current EIS process does not evaluate the possible extraction of coal or other natural resources for offsetting the construction costs (J. Workman, Personal Communication, April 29, 2011; D. Cramer, Personal Communication, May 12, 2011). The current EIS process in West Virginia includes the following factors that are quantified for each corridor being evaluated and are consistent with Federal Guidelines for Environmental Impact Statements (West Virginia Departament of Transportation, 2000):

- Roadway Length

- Preliminary Construction Cost

- Displacements

o Number of Residences

o Number of Businesses

o Number of Community Facilities

- Environmental Justice (Disproportionate Impacts)

o Low- Income Populations

o Minority Populations 
- Architectural Resources Impacted

- Archeological Resources Impacted

- Air Quality Improvements

- Energy Savings Due to Travel Efficiency

- Noise Impacts

- Federally-Listed Rare, Threatened Endangered Species

- Wetlands

- Wildlife Habitat Units

- Intermittent and Perennial Streams

- Floodplains Encroachments

- Prime/State-Wide Important Soils

- Potential Hazardous Waste Involvements

The Federal Highway Administration under the National Environmental Policy Act (NEPA) (U.S. Department of Transportation - Federal Highway Administration) provides a list of elements that may have an impact on highway construction projects (West Virginia Department of Transportation, Division of Highways, 1994). These elements are:

- Current and future level of service of existing transportation network,

- Current and future transportation demands,

- Regional and local system linkage,

- Safety and roadway deficiencies,

- Social demand, and

- Economic demand. 
Figure 1 illustrates the process for the development of a typical transportation project. It first depicts duration of the project, usually from one to 10 years. The second component of phases, the construction component, includes: Planning studies, environmental studies, preliminary design, final design, and right of way engineering/engineering and acquisition. 


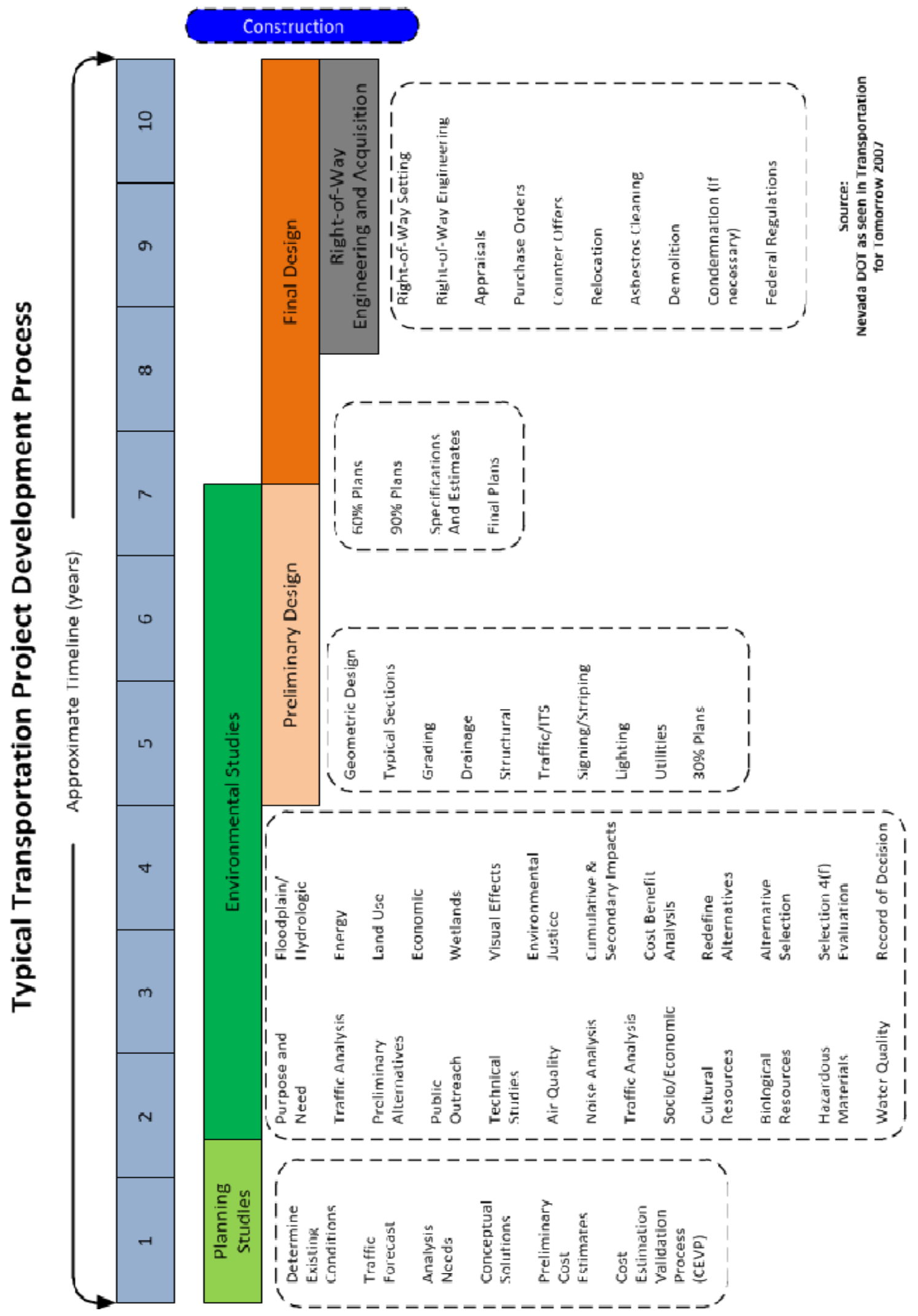

Figure 1 Traditional Environmental Impact Study 


\section{Chapter 3}

\section{Methods}

This study developed a tool based on a geospatial model for highway site selection using spatial data integration and geospatial analysis. The spatial data integration was achieved by combining an inventory of all cadastral layers (e.g., minerals, topography, and environmental features) with a grid-based system to determine the proximity to the proposed highway alignment. The result of this method provided an understanding of the importance of spatial analysis of coal resources in proposed transportation infrastructure by pattern analysis of the grid-based approach.

The geospatial analysis method to relate coal data to roadway alignment for the target roadway used proposed West Virginia Department of Highways roadway alignments, accounted for United States Environmental Protection Agency (U.S. EPA) constraints on coal extraction, and developed an evaluation using the best practices for developing geospatial analysis tools as described by Haining (Haining, Spatial Data Analysis Theory and Practice, 2003). Haining's analytical method provided a framework for a systematic approach for site evaluation, relying on geospatial ontology. A typical ontology is a representation of objects that are important criteria for the geospatial model. The properties of the objects in the coal data and roadway alignment model, and the relationship among them can be described in a first order logic statement:

$$
\left.\left.\left(\begin{array}{lllll}
(\boldsymbol{A} & \boldsymbol{B} & \boldsymbol{C} & \ldots . & \boldsymbol{n}
\end{array}\right)_{g}\right)\right\urcorner \boldsymbol{C F}
$$

Variables $A, B, C$ to $n$ are quantitative representations of existing coal seams (e.g., volume, energy content, ash, sulfur), conjoined in grid function $g$. The grid value is negatively correlated 
with the constraint factors $C F$. For example, a gas well would negatively impact the coal extraction due to the cost of sealing the well and compensating the owner.

The research will evaluate other variables inside the grid using a weighted exclusion function described by:

$$
\begin{gathered}
W_{i}=1 \forall g \\
W_{i}=\emptyset \text { for } g \cap W B
\end{gathered}
$$

Where the weight of each grid $W_{i}$ is equal to a maximum value of one in the grid $g$, and a null value $\varnothing$ in the case where a water body $W B$ intersects the grid. Other weighted exclusions were based on Watson's geological survey that involved: distance to streams, parks, populated and urban areas, oil and gas wells, and pipelines (Watson, 2007).

The Unified Modeling Language (UML) was used to model the Area of Interest (AoI). The spatial weighting function will follow Lee's (Lee, 2005) framework and Federal guidelines as described by Watson (Watson, 2007).

The spatial coal analysis developed a volumetric approach to assess the availability and coal grade for surface mining in a spatial context. The following equation has been modified from the West Virginia Legislative Rules State Tax Commission for surface mining which was developed for underground mining (T. Braggs, Personal Communication, June 10, 2011).

$$
\begin{gathered}
\text { Total tons }_{\boldsymbol{g}}=\sum_{\boldsymbol{n}}^{\boldsymbol{i}} \text { tons }_{\boldsymbol{i}} \\
\text { tons }=(T h k) X(a c) X(1800) X(R R)
\end{gathered}
$$

Where: $\quad$ tons $=$ Reserve Property Coal Quantity 


$$
\begin{aligned}
& T h k=\text { Thickness in feet of coal bed } \\
& a c=\text { areal extent of coal bed } \\
& R R=\text { Clean coal recovery rate }
\end{aligned}
$$

The thickness Thk is known and has been supplied by the West Virginia Geological and Economical group. The area will be constant according to the grid size. The recovery rate for the purpose of the research was 65 percent. This number was suggested by Mr. Braggs from the West Virginia Property Tax Division during an interview (T. Braggs, Personal Communication, June 10, 2011). The West Virginia Legislative Rules (Title 110 West Virginia Legislative Rules State Tax Comission Series $\S 110-1 \mid-3.19)$ describes that clean coal recovery rate is:

Clean coal recovery rate" is a decimal representing the percentage of marketable coal that is recovered, whether the coal is classified as run-of-mine-clean or washed-clean. The clean coal recovery rate must reflect the difference between calculated whole bed tonnage (tons-in-place) and mined tonnage as reported to the Office of Miners' Health, Safety and Training; or decimal representing an estimate of clean coal that may be recovered based on estimated tons-in-place, estimated mine recoveries and estimated wash recoveries based on area and coal bed information derived from taxpayer reports, other taxpayer-supplied information, publicly-available information, and other information that comes to the attention of the Commissioner. 


\section{Deployment Using Geospatial Modeling to Evaluate Project Benefits}

Although coal may exist along a roadway alignment, additional constraints are imposed by the United States Environmental Protection Agency that may prevent the coal from being extracted. The following proximity constraints are applied to the distance of the surface mine to areas of interest (Watson, 2007):

- Distance to streams must exceed $100 \mathrm{ft}$

- Distance to water bodies must exceed $100 \mathrm{ft}$

- Distance to parks must exceed $300 \mathrm{ft}$

- Distance to populated places must exceed $300 \mathrm{ft}$

- Distance to urbanized areas must exceed $300 \mathrm{ft}$

- Distance to oil and gas wells must exceed $200 \mathrm{ft}$

- Distance to pipelines must exceed $100 \mathrm{ft}$

Another difficulty in analyzing the extraction of coal to offset the construction costs is assigning a monetary value to the coal. West Virginia Legislative Rule Series 11 Valuation of Active and Reserve Coal Property for Ad Valorem Property Tax Purposes, West Virginia Legislative Rules State Tax Comission, provides a procedure for valuing underground coal reserves for property tax purposes (W. Va. Code § 11-1A-11 and §11-1C-5(b)); (T. Braggs, Personal Communication, June 10, 2011). However, this value is not necessarily related to the value of the coal once it is removed and sold, which is what coal companies will base their decision on to participate in the project (Braggs, 2011). It is not possible to account for all of the factors, some of which are proprietary, in assigning a value to the coal. Instead, it is most logical for the Environmental Impact Statement (EIS) process to quantify the amount of coal to be extracted, as well as its quality, for each possible alignment. This information would allow the coal companies and the 
West Virginia Department of Transportation (WVDOT) to make a determination regarding whether coal extraction is feasible. If so, the benefits of the extraction would be accounted for in the reduced construction cost estimate for that alternative. Figure 2 is a representation of the proposed Watson (2007) model. 


\section{Proposed Coal \\ Assessment}

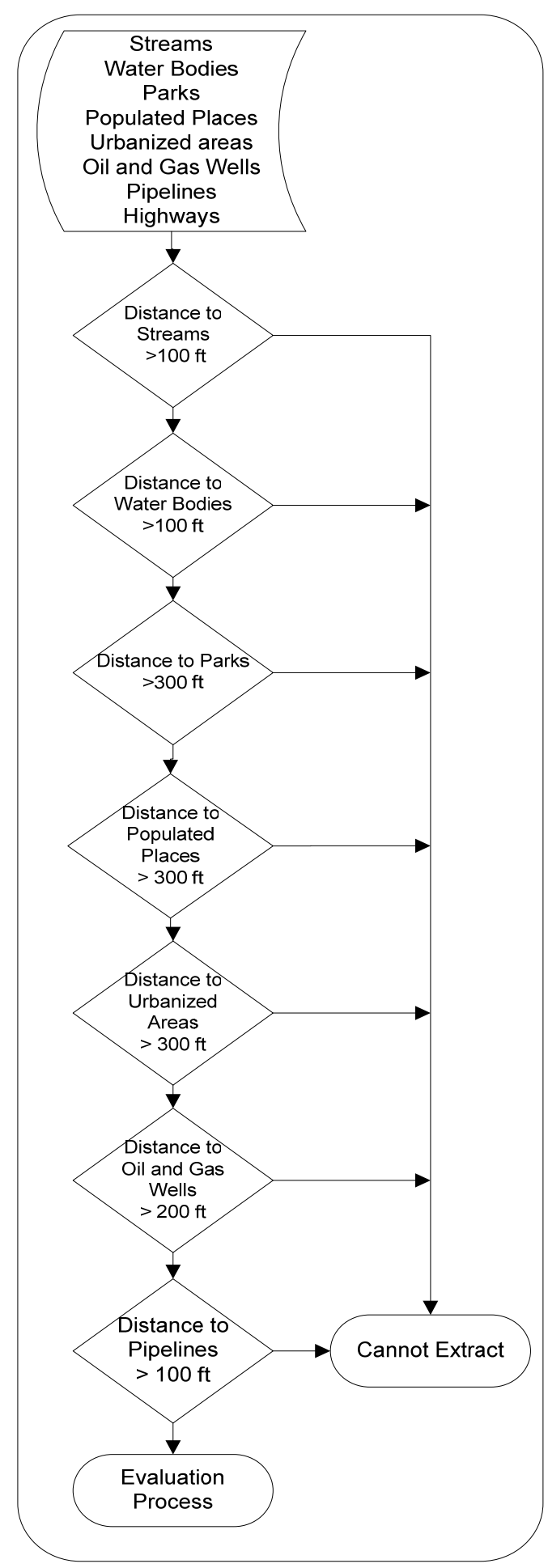

Figure 2 Coal Assessment 


\section{Case Study}

\section{Public Private Partnerships in West Virginia}

\section{Legal Framework}

Professor Judith W. Wegner J.D. from the University of North Carolina School Of Law states the legal framework in the paper (1987) Public Private Partnerships for Financing Highways Improvements. According to Wegner (1987), Public Private Partnerships have two basic principles: 1. The local governments may not approve alternative financial instruments without adequate support from the authority and 2 . Local government must be in compliance with Federal and State laws as a measure to limit possible excesses.

The current developments in West Virginia can be placed in Development Agreements, a welldefined legal structure in the Research Results document written by Wegner (Wegner, 1987). The legal definition stated under Development Agreement consists of agreements between local governments and developers, usually sanctioned by state stature set out various use limitations and infrastructure/public facility exactions sought by the former, and the freezing of land use controls for a fixed period together with service guarantee for the later. According to Wegner (1987), the document focuses on bilateral agreements because of the absence of case law on specific development agreements.

Bilateral agreements should include five general concepts in their legal framework (Wegner, 1987):

1. An applicable Master Use Land Plan is specified; 
2. A time frame for the development in appropriated circumstances is established;

3. Compliance and modification or termination under appropriated circumstances is proven;

4. Applicable State and Federal Laws will continue to apply as will local regulations such as environmental and proper taxation. Under certain circumstances, health and safety concerns will also apply; and

5. Other possible permits or approvals required for the development are defined.

The following map (Figure 3) displays the National I-73/I-74/I-75 Corridor, which includes the Area of Interest (AoI). The corridor extends from the United States/Canadian Border to Myrtle Beach, South Carolina. 


\section{Proposed National I-73 / I-74 / I-75 Corridor}

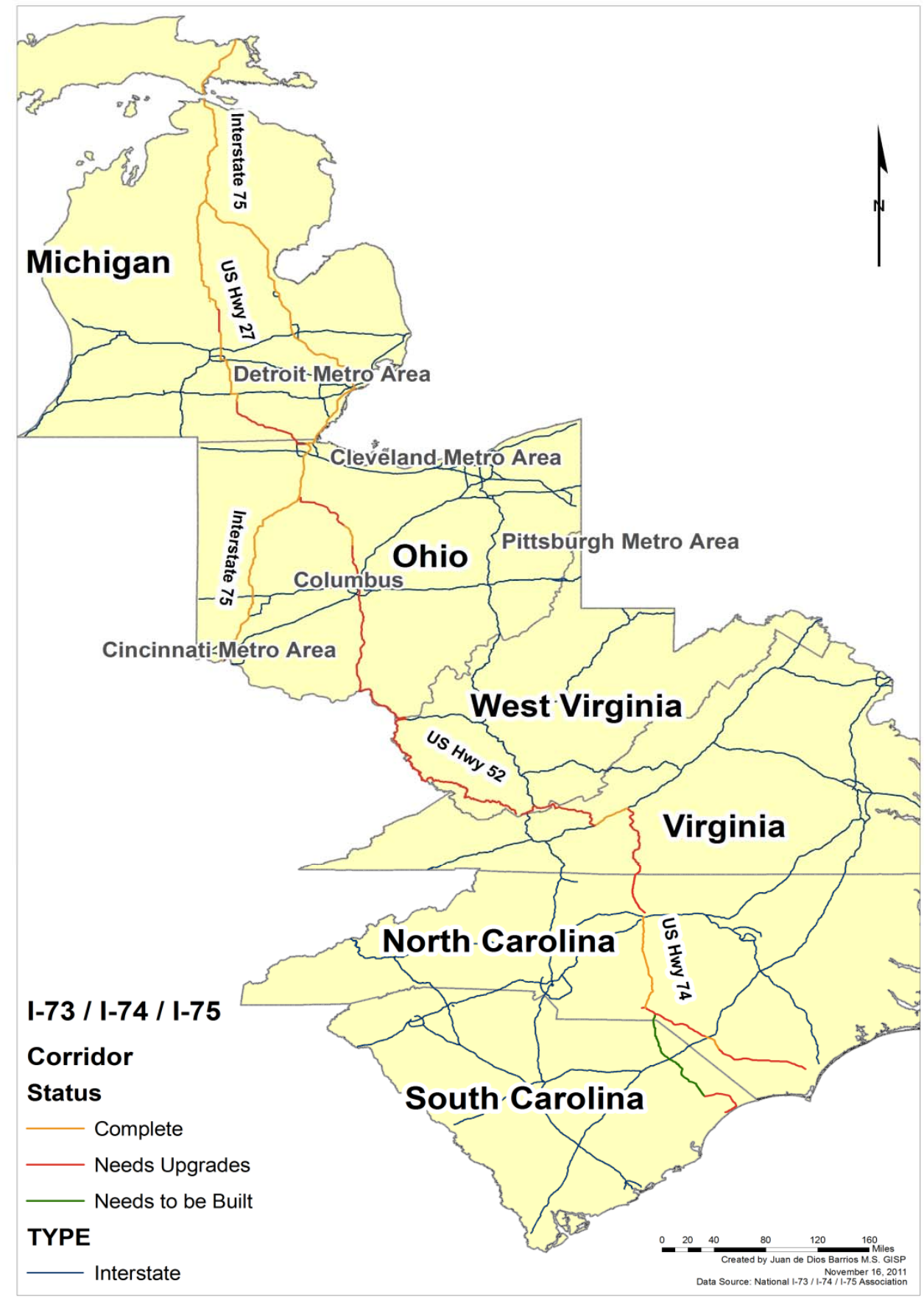

Figure 3 National I-73 / I-74 / I-75 Corridor 
The future reauthorization of the Federal Highway Bill has ignited a huge interest in Public Private Partnerships (Rahall, 2011). Another important factor supporting Public Private Partnerships (PPPs) is the American Jobs Act, which addresses the need for job creation through increasing investments in transportation or investments in transportation infrastructure. This allocation of resources will ensure the adequate level of service as an area that requires additional investment, or infrastructure. Since the United States Secretary of Transportation, Ray LaHood, stated that increase of the highway fees and taxes are "off the table," investors are attracted to PPP in the traditional and emerging sectors, such as the high speed train (Parsons, 2010).

Public Private Partnerships will be an important source for funding infrastructure in the near future. As stated by Miller (pp. 5), "Federal funding for big projects is over. Congress has taken a different approach regarding building, rehabilitation and maintenance of the national infrastructure."

In West Virginia, Paul Mattox, Secretary of Transportation, publicly stated: "While all traditional funding sources have been explored to complete the remaining unfinished section (of Interstate 35) the only remaining funding source being explored is the option of tolling" (West Virginia Department of Transportation, 2010). This tolling alternative has not been viable or appealing to the West Virginia State Senate or to the counties in the state. On March 3, 2011, the State Senate voted on the toll road funding legislation (SB606), which was rejected by a 12-21 margin. The opposition at the county level was shown by the Mason County Commission, November 10, 2010, when the commission reversed (2-1 votes) the first approval motion to 
install tolls for U.S. 35 financing. Representatives of the West Virginia Department of Highways had stated that alternative revenue sources are currently not available to fund the remaining stretch of highway and upgrading the current route is the only feasible alternative under these circumstances (Kabler, 2011).

The 65-mile long Coal Field Express Highway in Mingo County was the first project in West Virginia that involved the extraction of coal to offset the construction costs. However, this project did not include a formal evaluation of the coal extraction (Coalfields Expressway Authority, 2000). The lack of a formal evaluation makes it difficult to validate the decision to allow coal extraction. The logical time to evaluate the feasibility of coal extraction is within the project development process (D. Cramer, Personal Communication, May 12, 2011).

Although the proposed Public Private Partnerships approach for the King Coal Highway $(\mathrm{KCH})$ is sui generis or unique in the area of innovative or nontraditional PPP solutions to highway infrastructure, previous projects offer important information about the knowhow for the implementation process. The Red Jacket portion of the $\mathrm{KCH}$ in West Virginia and the Coalfields Expressway in Virginia are two examples of this implementation (Castle, 2011). It is important to note that these cases are precedent of how agreements were formerly created regarding the design build (D-B) phase of highway construction.

King Coal Highway Project

The study area for the King Coal Highway involves Mingo, Logan, McDowell, Wyoming and Mercer Counties. The corridor has 154 Km ( 96 miles) from Williamson WV (US 52 \& US 119) to Bluefield, WV (I-77). 


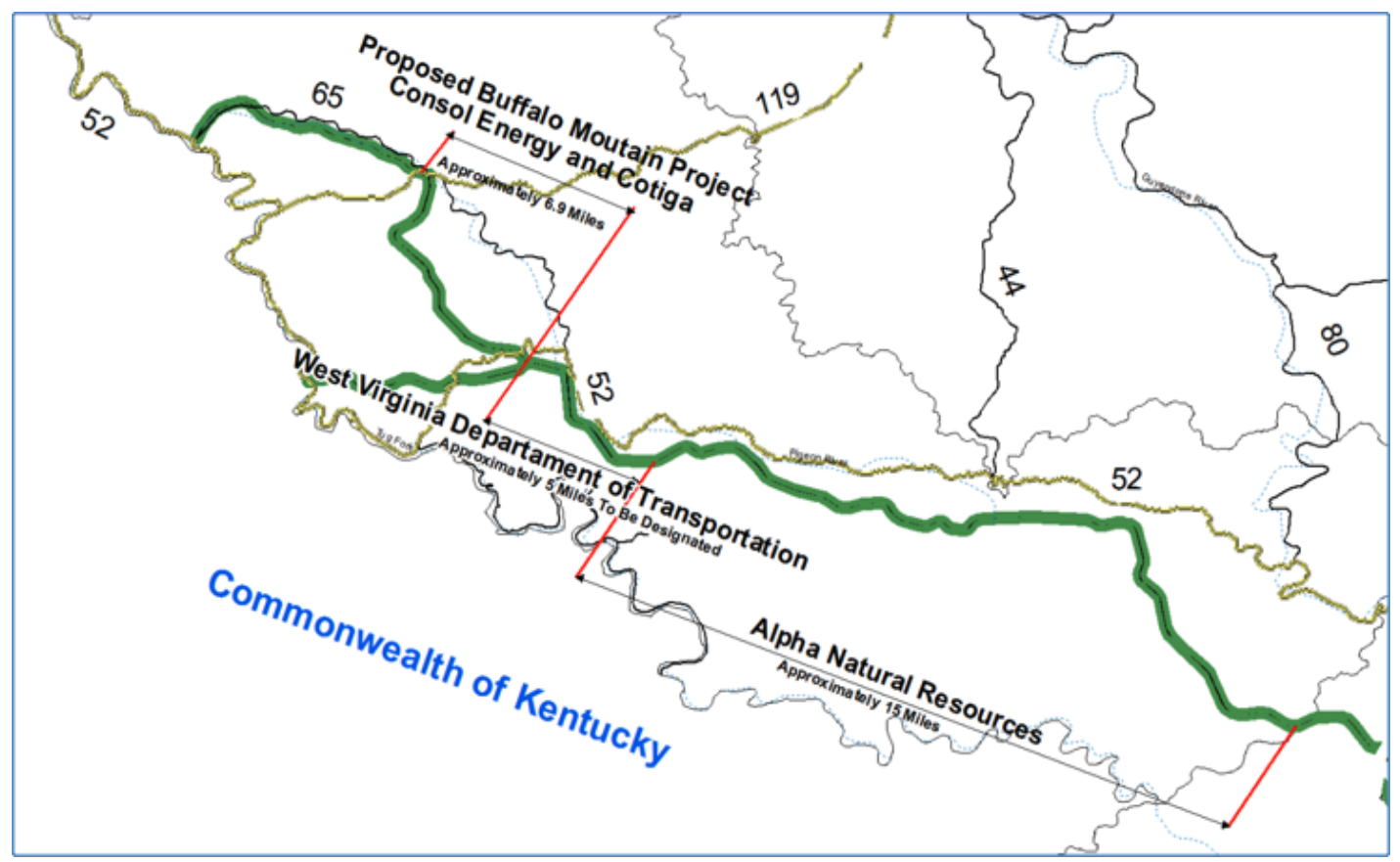

Map Created by Juan de Dios Barrios

Figure 4 King Coal Highway

\section{Red-Jacket Project}

The Red Jacket portion is the first of the 11 usable and operationally independent stretches of highway that will comprise the entire King Coal Highway $(\mathrm{KCH})$ corridor (Rahall Transportation Institute and Center for Business and Economic Research, 2011). The 11.2 mile stretch of roadway in Mingo County represents the first phase of highway construction for the $\mathrm{KCH}$ and the first phase of cooperation within a unique Public Private Partnership (PPP) arrangement (Rahall Transportation Institute and Center for Business and Economic Research, 2011). This is depicted in Figure 4. Alpha Natural Resources (ANR) partnered with the West Virginia Division of Highways to form an agreement where ANR will remove coal from the highway area though surface mining which will leave rough roadbeds. The total project cost was estimated at $\$ 110$ million. However, utilizing the unique PPP arrangement enabled more than a 50 percent cost savings to the project (Federal Highway Administration, n.d.) as compared with traditional construction methods. This traditional highway construction method uses 
eminent domain for properties along the select design (Rahall Transportation Institute and Center for Business and Economic Research, 2011). Figure 5 illustrates the Red Jacket segment in Mingo County.

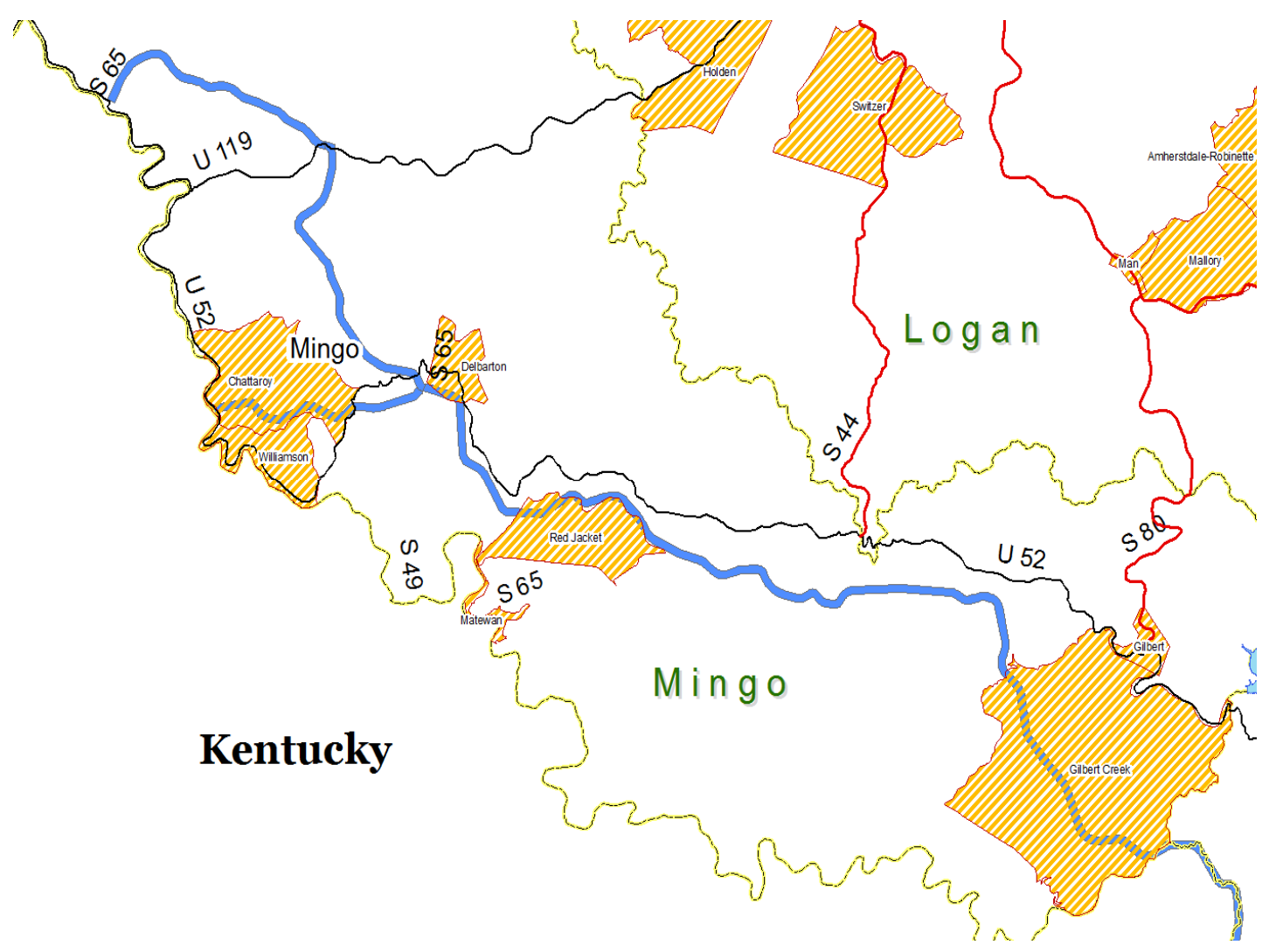

Figure 5 Proposed Red Jacket Project

The site also created 75 acres for a new consolidated Mingo County high school and another 1500 acres of land that can be used for development in the future (Ali, 2007). Building the highway was seen as a constructive public benefit, and therefore, served as justification for permitting coal extraction (Federal Highway Administration, n.d.).

Another key aspect of this project was the Federal and State incentives that were provided to fund it. The Federal Highway Administration provided \$15 million for the initial highway fill 
construction under the notion that the investment would create economic opportunity and jobs in Appalachia (Keeter, 2004). The State would provide the remaining funds necessary for project completion. For instance, it is indicated in the partnership between the original contractor, Nicewonder (now ANR), and the West Virginia Division of Highways (WVDOH) that certain levels of coal extraction can decrease subsidies. The document offers the possibility of a discount for the WVDOH if the coal extraction in the Area of Interest (AoI) is 1.5 to 2.5 million tons of coal. WVDOT calculates the discount as follows:

...multiplying the marketable tons recovered during the same time period as the progress payment invoice by an economical overburden to coal ratio of 14 in-place cubic yards and then multiplying this result by the unit cost of $\$ 1.65$ per in-place cubic yard for excavation units removed from the project area (WV Department of Transportation, 2004).

Another variable in the equation for the amount of discount is the price of coal (Castle, 2011). The original estimation for the cost projection was around $\$ 110$ million. In the Red Jacket case study, the Federal Highway Administration projected a lower estimate of around $\$ 90$ million due to increases in energy costs in recent years, more specifically, an increase in the cost of coal. Therefore, with price fluctuations and the discovery of more than the calculated surface coal, the amount of substantial reduction can be applied for future King Coal Highway projects.

In a personal interview with Michael Castle J.D., President of Strategic Solutions LLC, a company that provides legal consulting to the coal industry and serves as a leading consultant for ANR, Castle stated, "We're extracting coal, that under normal circumstances we would not be 
able to do." The volume of surface available coal was not enough for a traditional surface mining extraction; the only possible solution is the extraction of surface coal as a transportation or development byproduct (Castle, 2011). Federal law permits the extraction of coal as a byproduct of the construction process, which under normal circumstances would not be economically feasible to extract. The amounts of coal that were recovered were enough to help offset some of the costs of designing the roadbed (Ali, 2007).

Dr. Castle (2011) also pointed out during the interview how the roadway was compacted within a mining perspective rather than a construction point of view, "We were hauling the coal at the same time we were compacting the roadbeds." Triad Engineering was contracted as a third party independent consultant to verify the validity of budgeted line items presented by Alpha. ANR developed a pre-construction, during-construction, and post-construction, site baseline used during the reconciliation period where negotiations for reimbursable costs to Alpha were made (WV Department of Transportation, 2004).

Another key feature laid out in the agreement between the construction firm and the West Virginia Department of Highways was the exemption of certain labor laws such as the Davis Bacon Act and Chapter 21 Amendment 5 of the West Virginia State Code. The Davis Bacon Act refers to "all workers participating in all public works projects over $\$ 2,000$ be compensated based on the prevailing wages of the local area with comparable fringe benefits to other projects of a similar nature" (United States Department of Labor). The provision in the West Virginia Code (WV Code $§ 21-5 \mathrm{~A}-2$ ) is a similar state law which declares that prevailing local wages be paid to those "employed by or on behalf of any public authority engaged in the construction of 
public improvements." This term is a broad term and generally includes almost all types of infrastructure or public works, including buildings, roads, sewers, ditches, and sewage and water treatment plants (West Virginia Code §21-5A-2).

According to Peter W. Hahn, J.D., a lawyer who represents companies in labor disputes, prevailing wages are an approximation of the wages paid to workers in various building trades on private projects. There are different approaches to determining base wages. Some states, such as Ohio, calculate their base rate on collective bargaining agreements. Other states, such Kentucky, Pennsylvania and West Virginia, calculate the prevailing wage rates based on an average of the majority of workers in each trade where the work is performed (Hahn, 2011).

During the coal excavation process and the construction of the foundation for the roadway, the construction company was exempt from both The Davis Bacon Act and West Virginia State Code. These exceptions of the Davis Bacon Act and State laws are the grounds for several legal disputes between coal companies and unions (Castle, 2011). During the interview with Michael Castle J.D., President of Strategic Solutions LLC, he discussed the importance of the exception for the project. He addressed the importance of using non-union coal miners to "move the dirt" in the project. The project was considered to be a surface mine project. Therefore Castle (2011) indicated that to lower the overall project costs, certain laws had to be temporarily exempted for Alpha so the foundation could be built as quickly and cost-effectively as possible.

The researcher determined that the King Coal Highway Public Private Partnerships (PPPs) represented more of a special negotiated agreement between the two parties than a design-built 
format that is typical in other PPP transportation projects. Some costs were offset by negotiating subsidies based on volume and price of coal extracted (Castle, 2011). However, the majority of costs were to be reimbursed to Alpha based on specific line item costs submitted by Alpha and negotiated using third party criteria. Additionally, certain laws regarding prevailing wages were also exempt in this case; lowering the overall costs of the project to the state as well (Castle, 2011).

\section{Coalfields Expressway in Virginia}

The Coalfields Expressway (CFX) is a proposed multi-state corridor extending 116 miles from Pound, Virginia to Beckley, West Virginia shown in Figure 6. The rationale for building the new corridor was based on a similar approach as the King Coal Highway $(\mathrm{KCH})$. After U.S. Steel sold the last mine in 2003, the people of southern West Virginia began counting on the highway for economic development. "One of the promises we are waiting on to come is the highway" said Carolyn Falin, an Assistant Superintendent of Schools in McDowell County (The Associated Press, 2011).

In the article released by the associated press (The Associated Press, 2011), which interviewed several McDowell County residents, reported that the residents held expectations that the highway would develop the necessary transportation infrastructure for better accessibility through the coalfields region of southwestern Virginia and southern West Virginia.

Furthermore, it would be a catalyst for economic development in historically distressed regions.

In Virginia, the route will extend approximately 51 miles from Route 23 near Pound, Virginia westward toward the state line in Slate, Virginia (Virginia Department of Transportation, 2006). 
Within the context of Virginia's Public Private Transportation Act 1995 (Va. Code Ann. Title 56 Chapter 22, Virgnia General Assambly, 1994), the Virginia Department of Transportation entered into a comprehensive agreement with the engineering and construction contracting firm Kellogg, Brand, \& Root, Inc. (KBR) to design and build the expressway as a Public Private Partnership (PPP). By 2006, the Virginia Department of Transportation had entered into an agreement with Alpha Natural Resources and their subsidiary, Pioneer Group to assume KBR's responsibilities for further development of the Coal Field Expressway (Virginia Department of Transportation, 2006). As specified in the agreement, the coal companies involved will remove the coal that transverses the proposed alignment and will bring the terrain to rough grade for the highway (Alpha Natural Resources, 2008). Figure 6 illustrates the proposed multi-state corridor that will connect Beckley, West Virginia to Pound, Virginia. 


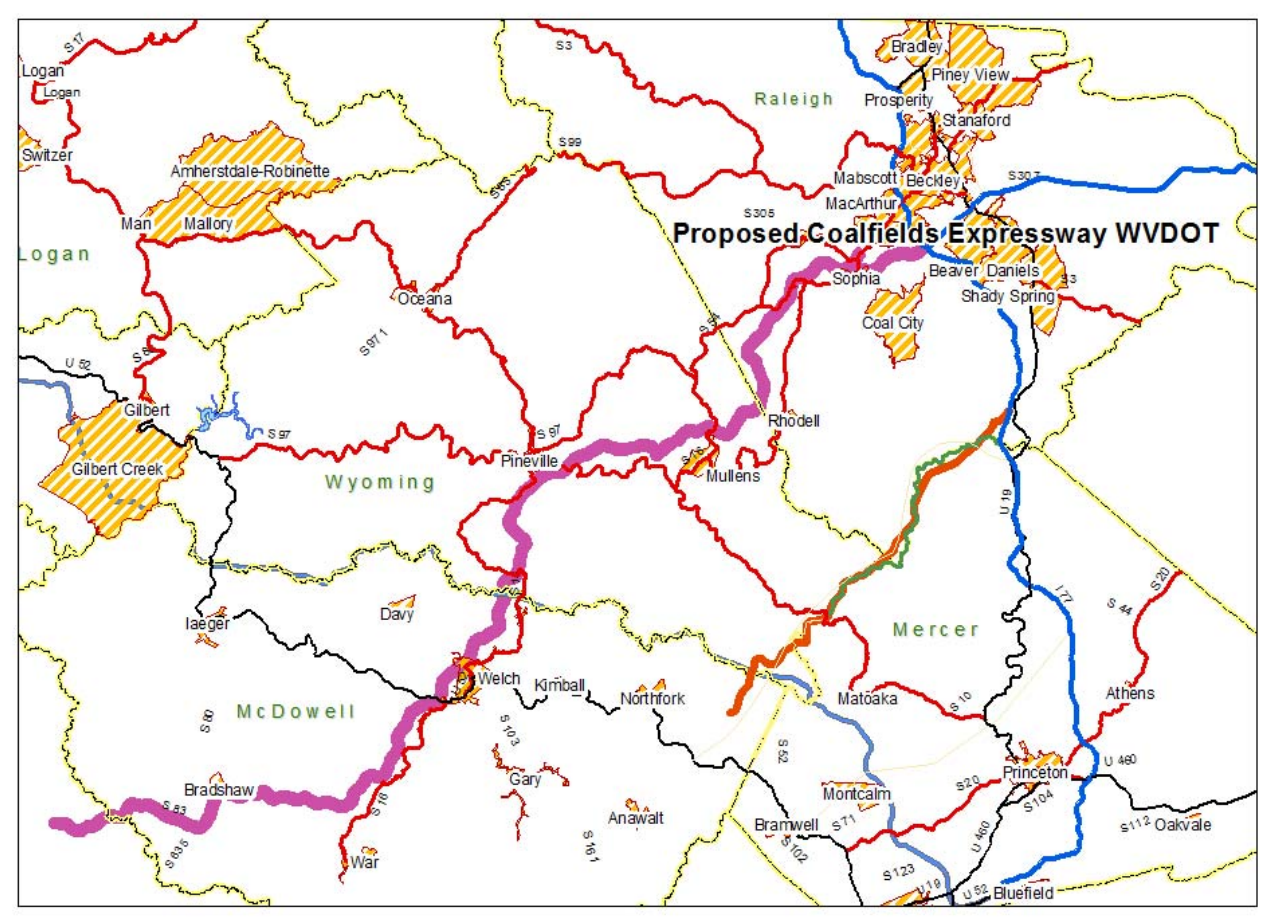

Figure 6 Proposed Coalfields Expressway

The Hawk's Nest portion of the Coalfields Expressway (CFX) is the first phase of construction that has been initiated (Coalfields Expressway Authority, 2000). This section begins at the 1.30 mile section of rough grade road bed will be constructed by Alpha in coordination with an active surface mining project in the highway area. The cost of construction of the Hawk's Nest section was estimated to be around $\$ 10$ million using the innovative Public Private Partnership option. This represents a savings of over $\$ 90$ million in comparison to constructing the roadbed through conventional standards (Virginia Department of Transportation, 2008). 
In April 2008, two $\$ 5$ million grants were approved by the State of West Virginia through the Transportation Partnership Opportunity Fund. Another $\$ 10$ million in total grants was awarded in March 2009. The $\$ 20$ million in total funds were allotted for use by the West Virginia Department of Transportation and Alpha in construction of the Hawk's Nest and Rockhouse stretches of the CFX (Virginia Department of Transportation, 2008). However, as of late February 2011, only a quarter mile stretch of the first phase of construction for the Hawk's Nest portion was completed (Archer, 2011).

Although the Hawk's Nest portion is yet to be completed, the contract between Alpha and the Virginia Department of Transportation regarding this phase provides valuable insight as to how the terms of the Public Private Partnership (PPP) were negotiated. With regard to scope, Alpha is responsible for developing to rough grade the 1.30 miles of four-lane roadbed within the Buchanan County, Virginia area. Virginia Department of Transportation (2008) amendment specifies that the coal company is responsible for developing a "minimum width of approximately 150 feet of right of way limits to accommodate the future development of a fourlane roadway which may include medians, shoulders, and highway drainage systems."

The amendment further requires Alpha to gather all applicable government and regulatory permits mandatory to conduct mining operations and to provide a copy to the Virginia Department of Transportation (VDOT) for their records. It was also pertinent that Alpha use its resources in "commercially reasonable efforts" to acquire the property within the Hawk's Nest area and donate it to the Department at their sole cost or expense. This stipulation includes rightof way (ROW) acquisition for the surfaces of all parcels within the section, and a declaration of 
restriction on future mining activities underlying the ROW (Virginia Department of Transportation, 2008).

Various stipulations for which the Virginia Department of Transportation (VDOT) is responsible regardless Alpha's compensation is also noted in the terms of the contract. Overall, the West Virginia Department of Transportation (WVDOT) is required to pay a fixed lump sum of $\$ 10$ million for Alpha's performance of the work in the Hawk's Nest Area. This figure represents the "contract price", and Alpha is to receive these payments in various installments. Initially, Alpha will receive \$1.5 million for the "development and implementation of design and construction plans, development and pursuit of permit revisions, and other ancillary work necessary, including engineering, for the development of the rough-grade roadbed" (Virginia Department of Transportation, 2008). The contract provides for this sum of money within the first six months by allowing six monthly installments of $\$ 250,000$. It is important to note that the Hawk's Nest Phase is further divided into segments. The 1.30 mile roadway consists of four .25 mile segments and a final segment which will be .30 miles. Thus, the remaining payment to Alpha, $\$ 8,500,000$, comes in five installments of $\$ 1,700,000$ contingent upon the completion of the five segments of the rough roadbed (Virginia Department of Transportation, 2008).

Finally, it is necessary to mention another fundamental incentive for Alpha beyond the payment for contractual services offered by the Virginia Department of Transportation. The contract also allows Alpha to remove underlying reserves; therefore, the company is incentivized by the possibility of extracting large amounts of marketable coal. Costs resulting from operational activities dealing with coal extraction are incurred at the expense of Alpha. However, the company ultimately aims to maximize its earnings by aligning the roadbed where underlying 
coal reserves already exist (Castle, 2011). In January 2006, Alpha and its subsidiary, Pioneer Group, conducted feasibility studies on possible roadway locations based on its alignment with areas where the company and its subsidiary already hold the rights to underlying coal reserves (Alpha Natural Resources, 2008). A key incentive for Alpha's participation in the agreement was that it has enabled them to gain broader mineral removal rights. The coal extraction from the project area was a necessary step for development of the roadway. At the same time, facilitation of the extraction process was made easier due to the joint cooperation between Alpha and governmental authorities (Castle, 2011). 


\section{Chapter 4}

\section{Research Results}

The research methodology was developed using the King Coal Highway project in southern West Virginia as a case study. Some phases of this highway have already been completed, but funding is being sought for additional phases of construction. The following tasks were completed for this project.

1. Developed a Geospatial Coal Map for the King Coal Highway.

a. Developed of Image Base Mapping.

- Software: Quantum GIS Version 1.8.0 "Lisboa".

- Data Sources: West Virginia GIS Technical Center.

- Data Type: 2003 and 2007 Digital Aerial Photography.

b. Developed of a Digital Elevation Model (DEM).

- Software: Quantum GIS Version 1.8.0 "Lisboa".

- Data Sources: United States Geological Survey.

- Data Types: 3 meters Digital Elevation Sets.

c. Developed of thickness coal model including.

- Coal Seams.

- Thickness Map.

- Software: Quantum GIS Version 1.8.0 "Lisboa",

- Data Sources: West Virginia Geological and Economic Survey, and West Virginia State Tax Department. 
- Data Type: ESRI Shapefiles.

2. Developed a Geospatial Analysis Method to Relate Coal Data to Roadway Alignment for the King Coal Highway.

a. Imported West Virginia Department of Transportation proposed roadway alignment into geographic information systems.

b. Accounted for the Environmental Protection Agency coal constraints.

c. Developed and evaluated a spatial representation (representation model) and the available variables to develop proper analysis tools (Haining, Spatial Data Analysis Theory and Practice, 2003).

d. Developed a systematic approach for site evaluation using Geospatial Ontology. A typical ontology is a representation of objects that are important criteria for the geospatial model, the properties of those objects that need to be included, and the relationship among them.

e. The geospatial model is characterized by Unified Modeling Language, which represents the Area of Interest.

- Software: Quantum GIS Version 1.8.0 "Lisboa".

- Data Sources: Previous Coal Models and alignment from the West Virginia Department of Transportation.

- Data Type: ESRI Shapefiles.

3. Computed Coal Extraction Metrics for the King Coal Highway.

a. Produced tonnage, seam width metrics for the currently proposed roadway alignment.

b. Met with project stakeholders to discuss metrics. 
- Usefulness.

- Accuracy.

- How they are best incorporated into the project development process?

- What factors will affect whether coal extraction is feasible along an alignment?

4. Documented the Methodology and Procedure for Producing the Metrics

Table 4 illustrates the developed conceptual analysis matrix taking as example the King Coal Highway, each one of the components are explained below:

\section{Analysis Matrix}

\begin{tabular}{|c|c|c|c|c|}
\hline Input & Objective & $\begin{array}{l}\text { Level I } \\
\text { Macroscopic }\end{array}$ & $\begin{array}{l}\text { Level II } \\
\text { Mesoscopic }\end{array}$ & $\begin{array}{l}\text { Level III } \\
\text { Microscopic }\end{array}$ \\
\hline \multirow[t]{2}{*}{ Proposed Route } & $\begin{array}{l}\text { Defining } \\
\text { Area of Interest } \\
\text { (AoI) }\end{array}$ & $\begin{array}{l}\text { Polygon } \\
\text { Definition }\end{array}$ & $\begin{array}{l}\text { Corridor } \\
\text { Definition }\end{array}$ & $\begin{array}{l}\text { Alignment } \\
\text { Definition } \\
\text { Center Line With } \\
\text { Right-of-Way } \\
\text { (RoW) }\end{array}$ \\
\hline & & $\begin{array}{l}\text { Overlay Polygon } \\
\text { Over Coal } \\
\text { Available }\end{array}$ & $\begin{array}{l}\text { Overlay Corridor } \\
\text { Over Coal Stacks }\end{array}$ & $\begin{array}{l}\text { Overlay } \\
\text { Alignment } \\
\text { Centerline Over } \\
\text { RoW }\end{array}$ \\
\hline \multirow[t]{3}{*}{ Static Layers } & Availability & $\begin{array}{l}\text { Total Coal } \\
\text { Available }\end{array}$ & $\begin{array}{l}\text { Amount of Coal } \\
\text { Extractable by } \\
\text { Coal Seam }\end{array}$ & $\begin{array}{l}\text { Calculation of } \\
\text { Coal Using Grid } \\
\text { for Extractable } \\
\text { Coal Seam }\end{array}$ \\
\hline & Constrains & Qualitative & Quantitative & Quantitative \\
\hline & Calculation & Total Volume & $\begin{array}{l}\text { Total Volume by } \\
\text { Coal Seam }\end{array}$ & $\begin{array}{l}\text { Total Volume by } \\
\text { Coal Seams With } \\
\text { or Without } \\
\text { Constraints }\end{array}$ \\
\hline
\end{tabular}

Table 4 Analysis Matrix

Table 5 exemplifies the developed practical analysis matrix for the case study. 


\begin{tabular}{|c|c|c|c|}
\hline Input & $\begin{array}{l}\text { Level I } \\
\text { Macroscopic } \\
\text { (Planning Studies) }\end{array}$ & $\begin{array}{l}\text { Level II } \\
\text { Mesoscopic } \\
\text { (Environmental } \\
\text { Studies) }\end{array}$ & $\begin{array}{l}\text { Level III } \\
\text { Microscopic } \\
\text { (Preliminary Design) }\end{array}$ \\
\hline $\begin{array}{l}\text { Area of Interest - } \\
\text { Width }\end{array}$ & $\begin{array}{l}\text { Corridor Width } \\
8.04672 \mathrm{Km}(\sim 5 \\
\text { Miles })\end{array}$ & $\begin{array}{l}\text { Preferred Alignment } \\
1.60934 \mathrm{Km}(\sim 1 \text { mile })\end{array}$ & $\begin{array}{l}\text { Limits of Construction } \\
250 \mathrm{~m}(\sim 820 \text { feet })\end{array}$ \\
\hline $\begin{array}{l}\text { Grid Size for } \\
\text { Volume } \\
\text { Calculations }\end{array}$ & $100 \mathrm{~m} * 2$ & $100 \mathrm{~m}^{*} 2$ & $25 \mathrm{~m} * 2$ \\
\hline $\begin{array}{l}\text { Coal Seam Depth } \\
\text { Considered }\end{array}$ & $\begin{array}{l}70 \mathrm{~m} \\
\text { (Referenced to Coal } \\
\text { Seams) }\end{array}$ & $\begin{array}{l}70 \mathrm{~m} \\
\text { (Referenced to Coal } \\
\text { Seams) }\end{array}$ & $\begin{array}{l}35 \mathrm{~m} \\
\text { (Referenced from Ground } \\
\text { Surface) }\end{array}$ \\
\hline Objective & $\begin{array}{l}\text { Coal presence and } \\
\text { rough amount }\end{array}$ & $\begin{array}{l}\text { Coal amount with } \\
\text { extraction constraints }\end{array}$ & $\begin{array}{l}\text { Coal amount with extraction } \\
\text { constraints }\end{array}$ \\
\hline
\end{tabular}

Table 5 Practical analysis

Figure 7 exhibits the core drillings of the sample area, located approximately 20 miles south of the lower part of the King Coal Highway alignment 


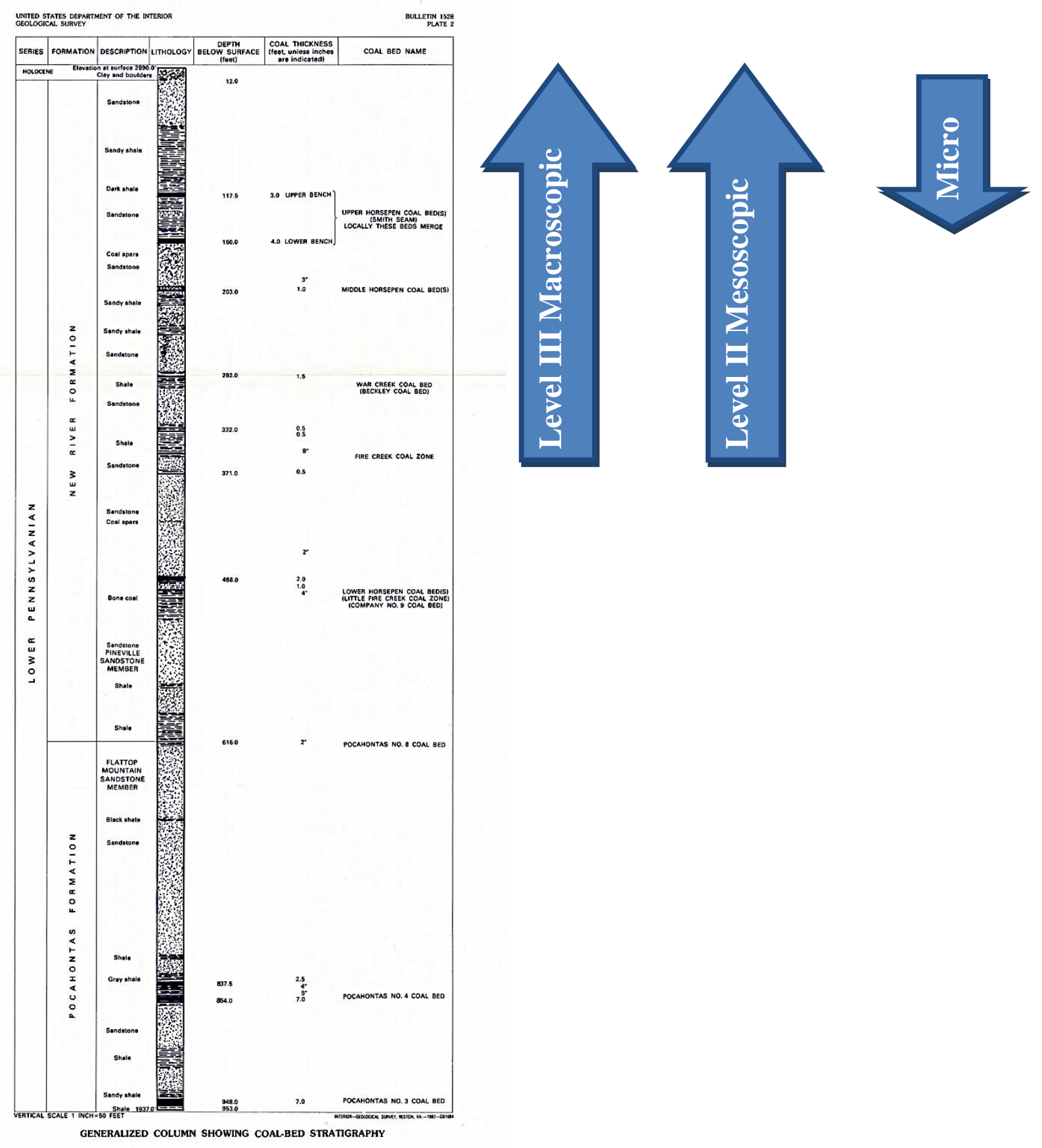

Figure 7 Core Drilling 


\section{Input}

\section{Proposed Route}

The main objective at each one of the different stages is to define the most suitable area for the construction of the road at different scales that includes: Macroscopic (Level I), Mesoscopic (Level II) and Microscopic (Level III). Figure 8 illustrates the Area of Interest corridor with the definition of Microscopic, Mesoscopic and Microscopic extent.

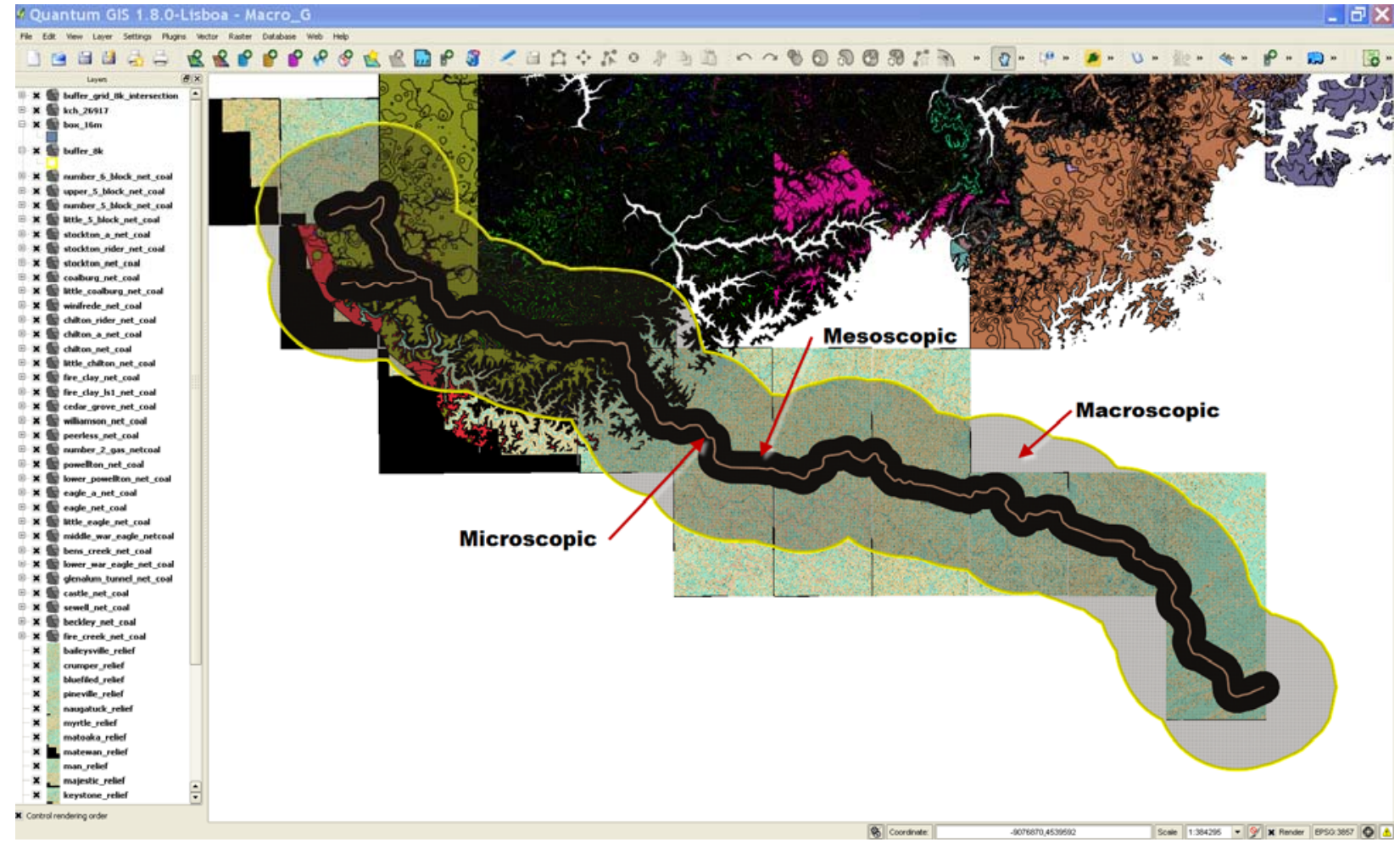

Figure 8 Area of Interest

At the Macroscopic (Level I), several corridors are defined as the possible areas for the road construction (J. Workman, Personal Communication, April 29, 2011; D. Cramer, Personal Communication, May 12, 2011). At this time, the area is roughly defined and several factors are taken into consideration such as conceptual solutions and preliminary cost estimates among others (reference Figure 1 and Appendix 1). For the purpose of this dissertation, the main goal 
of the phase is to determine coal availability in a simple query. The proposed analysis is the geospatial analysis (overlaying) of the corridor in a shapefile format with the best available coal shapefiles data. Additionally, a volumetric analysis of the area of interest (AoI), taking into consideration the surface mining constraint will be generated. The final products for the macroscopic analysis are the definition of several possible corridors, coal availability and presence of constraints for further analysis.

For example, the first alignments (Macroscopic Analysis) for the King Coal Highway were located at the ridge lines of the mountains; however, as the project moved to the Mesoscopic level, the personnel conducting the analysis discovered that extractable coal was not available at the suggested areas (E. Hohn, Ph.D., Personal Communication, November 17, 2010). At Mesoscopic (Level II) the Areas of Interest (AoI) are more defined and the analyses are based at the corridor level (previously defined at the macroscopic level). At this stage, the main objective is the spatial analysis of the corridor to determine the amount of coal extractable by ordered coal seams in a qualitative analysis, taking into consideration location based constraints, such as, gas well and pipelines (Figure 1 and Appendix 1). Order and location are key components of the Level II analysis because the methodology needs to take into consideration variables such as maximum depth of the coal seams for extraction and the order of the coal seams. Figure 9 illustrates the Mesoscopic Level II view with water constraints and terrain relief. 


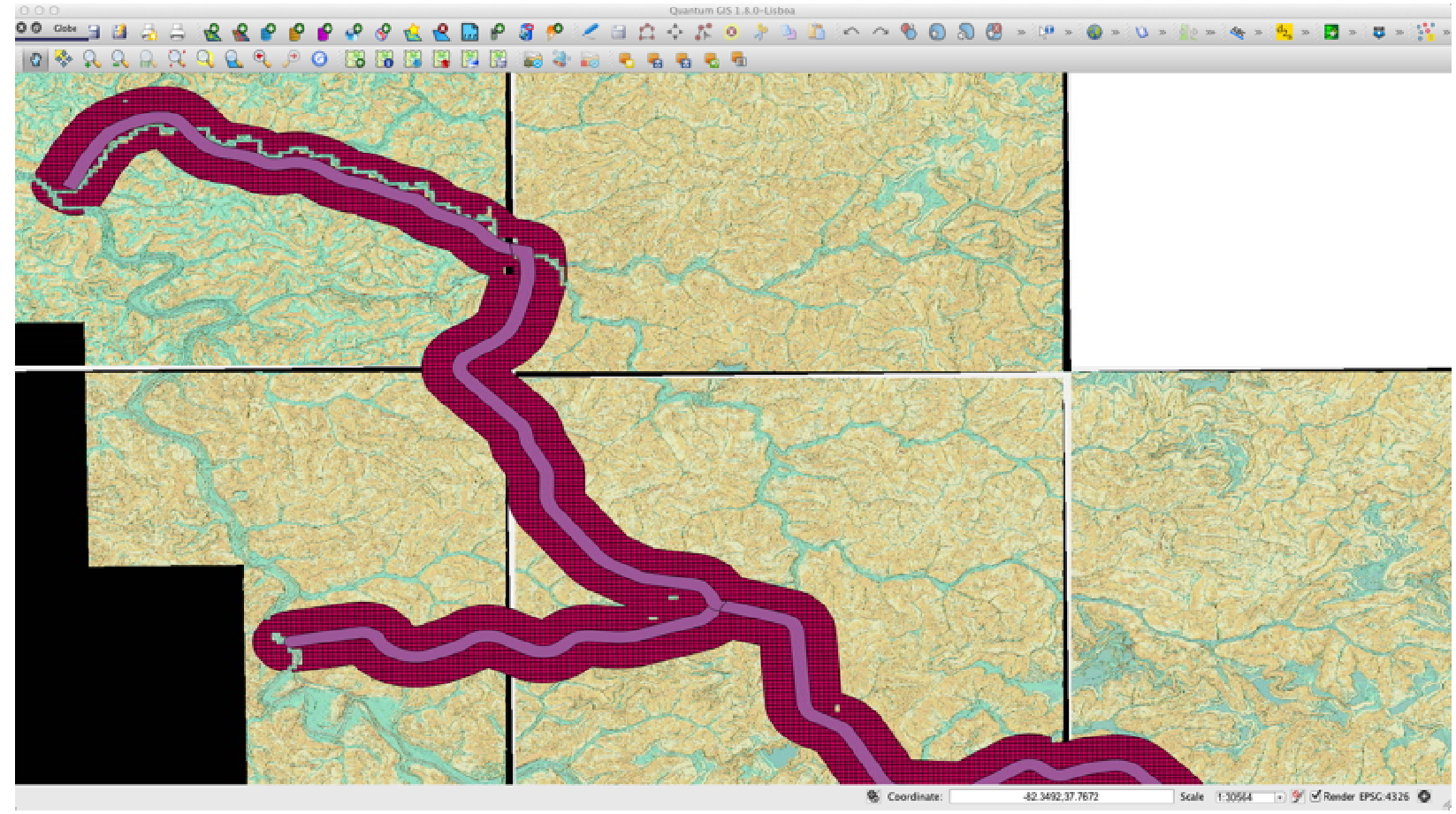

Figure 9 Level II Mesoscopic

In Microscopic (Level III), the best alignments are defined based on the center line. The conception of the most suitable AoI for the road bead is used to create a buffer zone according to the maximum distance of the Constraints Factors (CF). The resultant area is used to create a shapefile for the weighting grid. The grid will be used to calculate the importance of the constraints. The constraint factors have different impacts in the process. For example, while urban areas and parks will block the extraction of coal, gas wells can be sealed for the coal extraction or for construction. The final product is a summation of coal availability according to the stack of seams and the possible effects of the constraints in the potential alignment. Figure 10 illustrates the grid scale between Mesoscopic Level II and Microscopic Level III. One cell at Level II equals four cells at Level III. 


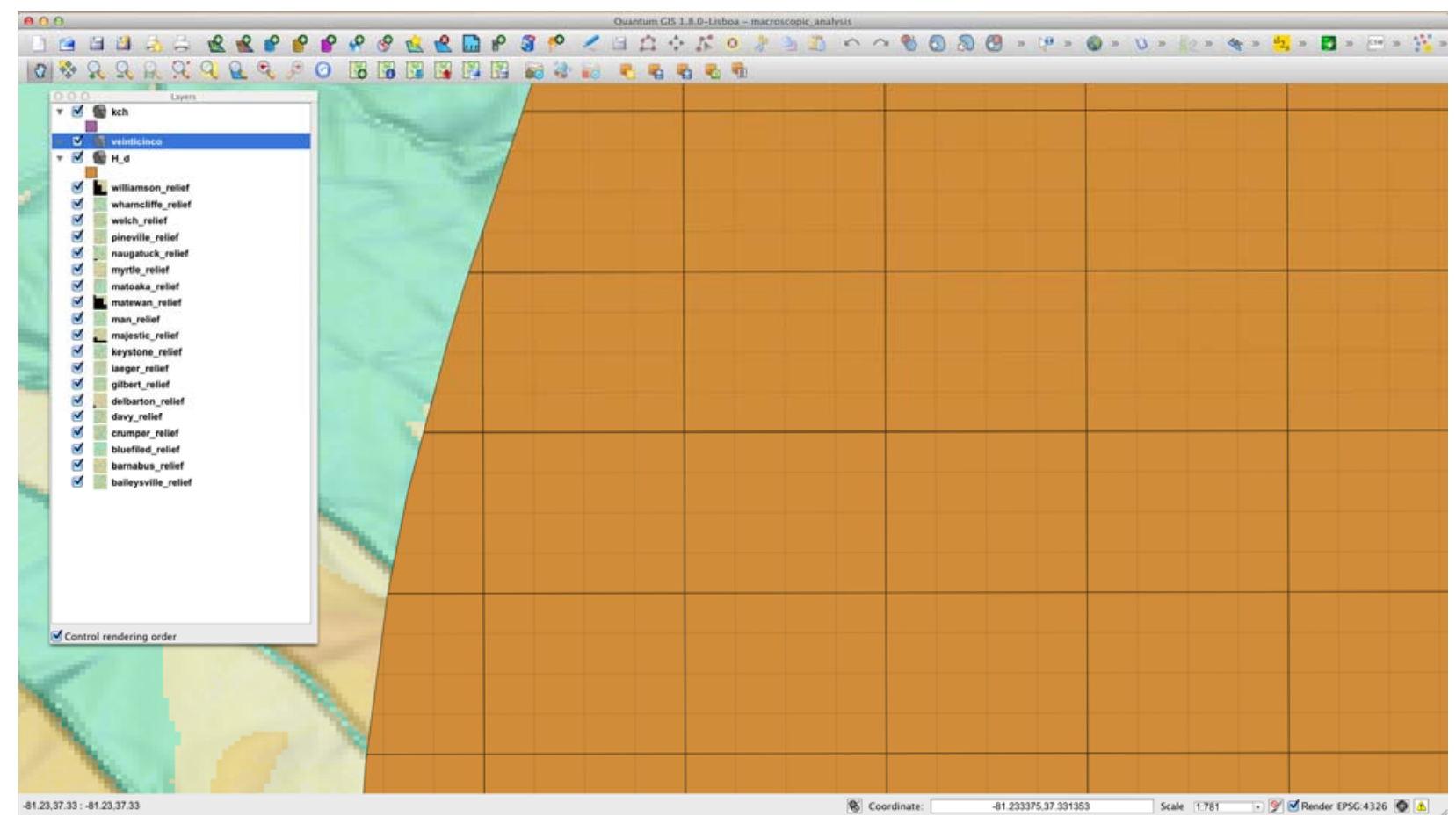

Figure 10 Level III Microscopic

\section{Methodology}

The geospatial model was created according to the First Order Statement from equation 3.1.

The system deployment was developed by the researcher to be a hybrid system allowing different software platforms to access the geodatabase from Open Source (i.e., QGIS and R) to commercial (i.e. Windows Office suite and Environmental Research Institute (ESRI) 10.1 suite). Special consideration was taken for the ESRI proprietary platform, because the research institute is the industry leader in geographic information systems. The only requirement for any platform to access the database is to be in compliance with Open Geospatial Consortium (OGC) standards (Open Geospatial Consortium, 2013). 
As stated by Quattrochi and Goodchild (1997) fractal measurements are used for boundary delineation such as land, water and vegetation areas. Another use of this type of technique is for spatial aggregation such as this dissertation. Fractals have the following properties: geometrically similar, shape/scales down by the same ratio and Euclid standard geometry (Mandelbrot, 1989).

The data analysis was based on Fractals using a Box Counting variation. Fractals provide a workable new middle ground between the excessive geometric order of Euclid and the geometric chaos of roughness and fragmentation.

The Box-Counting Method is based on the fact that the length measurement of contours increases with scale. The length of each contour line is approximated by overlaying a grid and counting the number of cells that intersect. By changing the size of grid cells, we can evaluate the effects of changing scales. As cells become smaller, finer details are captured (Quattrochi \& Goodchild, 1997).

The software geodatabase is PostgreSQL 9.1.4 on x86_64-unknown-linux-gnu, compiled by gcc (Ubuntu/Linaro 4.6.3-1ubuntu5) 4.6.3, 64-bit with POSTGIS=1.5.3 GEOS=3.2.2-CAPI-1.6.2 PROJ=Rel. 4.7.1, 23 September 2009 LIBXML=2.7.8 USE_STATS embedded as spatial engine. The Open Source administration tool was pgAdmin3. The desktop applications included ESRI suite 10.1 and Quantum 1.8.0-Lisboa (Figure 11 System Analysis Design). 


\section{System Analysis Design}

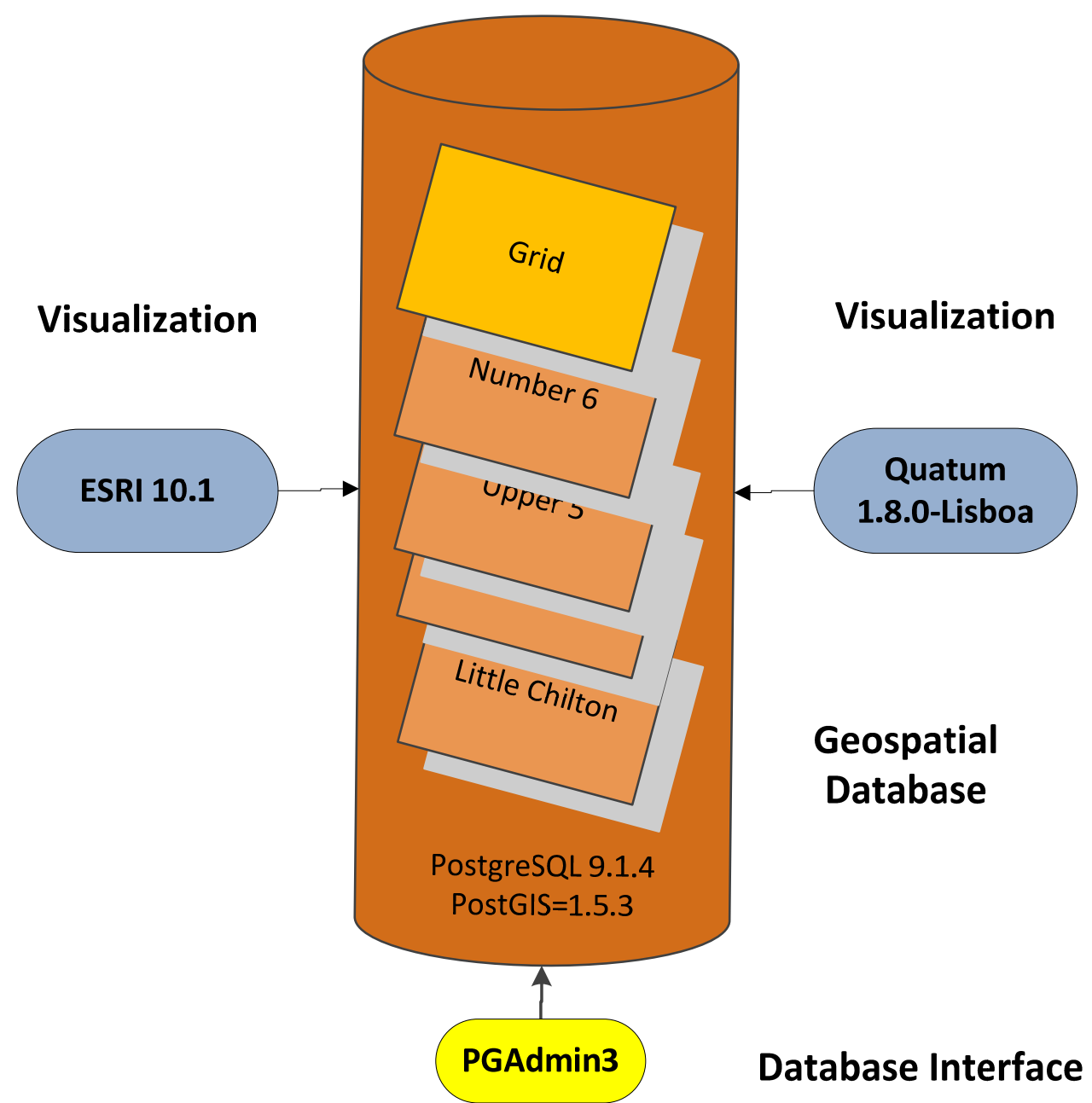

Figure 11 System Design

\section{Data Sources}

Coal Seams are generated by the West Virginia Geological and Economic Survey (WVGES)

Group dependent on the West Virginia Department of Commerce. The WVGES develops a Coal Bed Mapping Project (CBMP) with the objective of creating a Geographic Information System- 
based inventory of coal. All the information is available to the general public at (http://www.wvgs.wvnet.edu/www/coal/cbmp/goal.html). Figure 12 illustrates the different layers included in the Shapefiles. Each part has its own information regarding thickness in the attribute table.

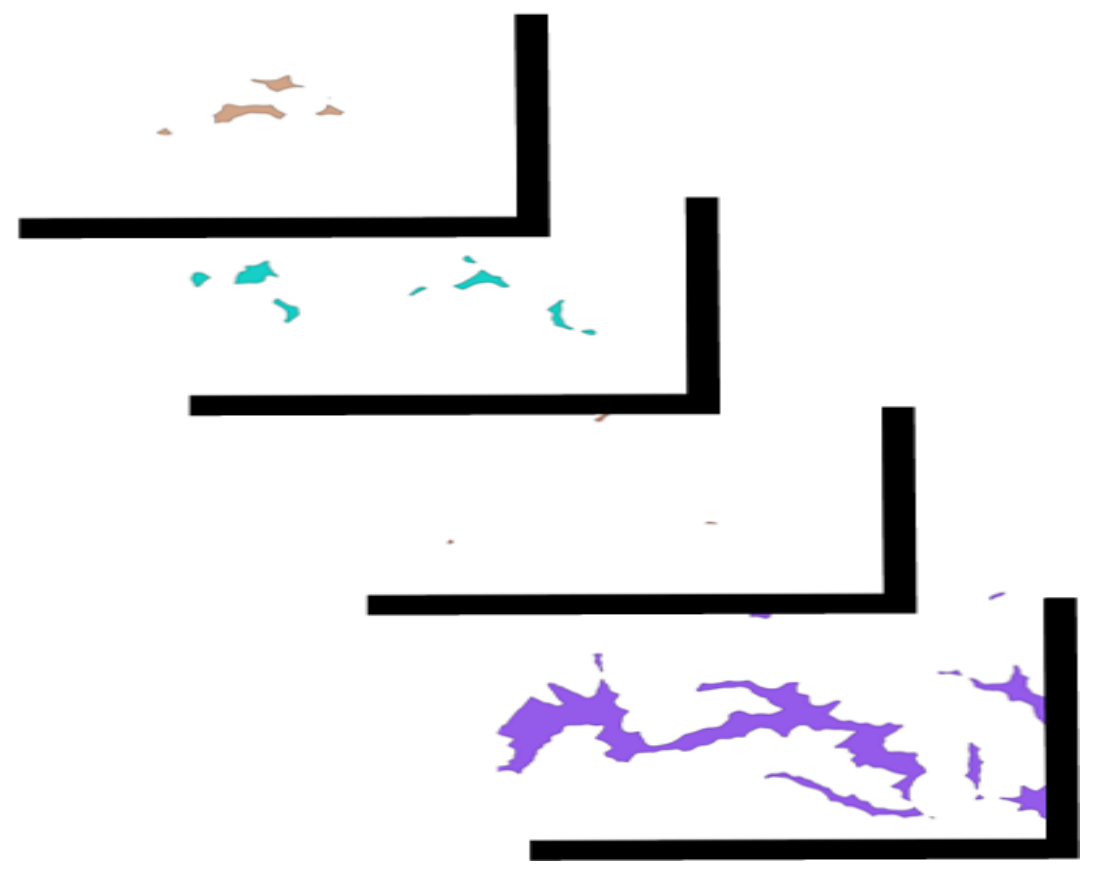

Figure 12 Coal Seam Information

Figure 13 represents the geologic map of the area of interest. This component is important for the validation of the coal seam vertical order.

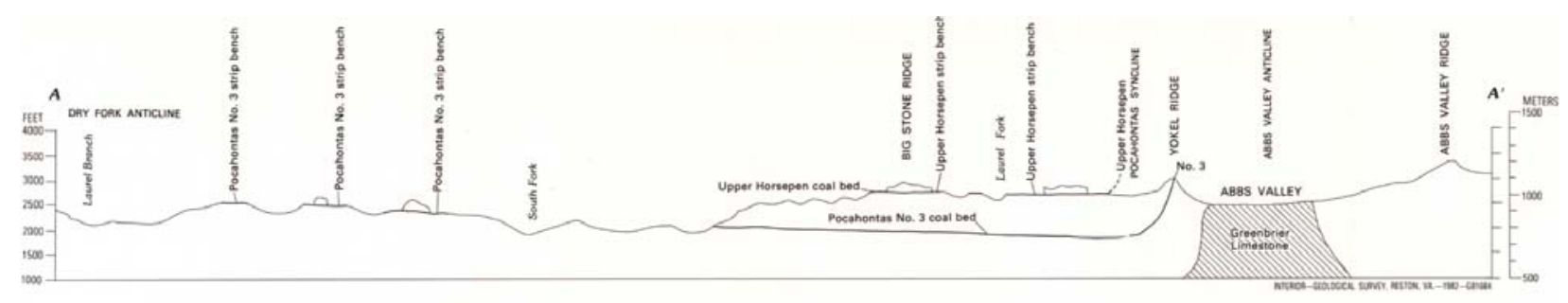

GEOLOGIC MAP OF THE STUDY AREA IN WEST VIRGINIA AND VIRGINIA

Figure 13 Geologic Map 
The Digital Elevation Models (DEM) are an array of elevation from ground positions at 3 meters. They are a part of the West Virginia Statewide Addressing and Mapping Board (SAMB) final product. The SAMB is hosted at the West Virginia Department of Homeland Security. The data were collected in 2003 with a Maximum Accuracy +-10 Feet (West Virginia GIS Technical Center, 2013).

The Digital Orthophoto Quarter Quads (DOQQ) can be acquired by several sources. For this analysis, a 0.60 meters dataset from the West Virginia Statewide Addressing and Mapping Project was used. This dataset is part of the Statewide Addressing and Mapping Board (SAMB) final product. The SAMB is hosted at the West Virginia Department of Homeland Security. The data was collected in 2003 (West Virginia GIS Technical Center, 2013).

The hydrography dataset used is a part of the West Virginia Statewide Addressing and Mapping Project (2003 SAMB). This data were processed by the West Virginia University GIS Technical Center, and can be access at (http://wvgis.wvu.edu/data/dataset.php?ID=265).

The streams dataset used is part of the West Virginia Statewide Addressing and Mapping Project (2003 SAMB). This data were processed by the West Virginia University GIS Technical Center and derived from the United States Geological Survey National Hydrological Dataset (NHD) and Digital Line Graphs (DLG). It can be access at (http://wvgis.wvu.edu/data/dataset.php?ID=204). 
The Public Land State Parks dataset used for this study is a Census 2010 file. The United States Census Bureau generates a GIS-based system for public usage. This data can be accessed at the West Virginia University GIS Technical Center (http://wvgis.wvu.edu/data/dataset.php?ID=203).

The Populated Places dataset used for this study is a Census 2010 Tiger File. The United States Census Bureau generates a GIS-based system for public usage at (http://www.census.gov/geo/www/tiger/shp.html).

The Urbanized Areas dataset used for this study is a Census 2010 Tiger File. US Census Bureau generates a GIS-based system for public usage. (http://www.census.gov/geo/www/tiger/shp.html).

The Oil and Gas dataset used for this study is generated by the West Virginia Department of Environmental Protection Office of Oil and Gas (DEP O\&G). The DEP O\&G is responsible for monitoring and regulating all parts of oil and gas wells across the state. (http://www.dep.wv.gov/oil-and-gas/Pages/default.aspx).

The researcher created a pipeline dataset after a proprietary map from the Columbia Energy Midstream. The data were converted from a PDF file to an ESRI shapefile, and collaborated by a heads-up digitalization specifically for the analysis of this research, but all pipeline information can be accessed from National Pipeline Mapping System (U.S. Departament of Transportation). Figure 14 illustrates oil, gas wells, urban areas, pipelines, populated places and water bodies of the area of interest. 


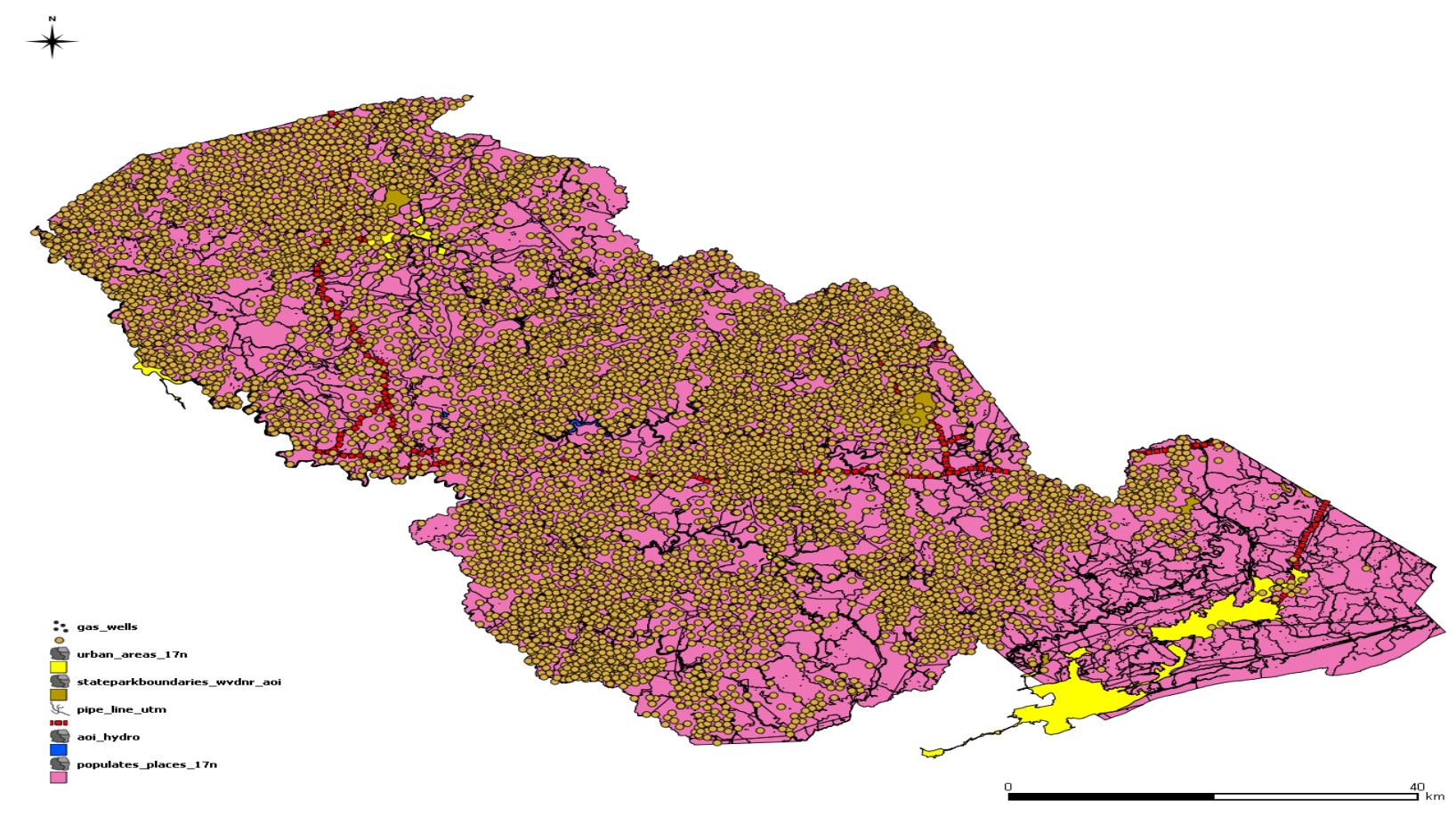

Figure 14 Environmental Feature Data

\section{Technique}

The researcher of this study re-projected data sources (shapefiles) from the original projection (i.e., state coordinate system) to Universal Transversal Mercator Coordinate System (UTM) 17N to have the same Spatial Reference System Identifier (SRID) in the geometry column of the geodatabase. The geometry column refers to a specific library built under PostGIS table to position the location in the world at the geodatabase level.

The major difference between ESRI software and QGIS is the geometry column name. ESRI's name is under a proprietary shape geometry column; QGIS uses geom as the name for the geometry column. Both have the capability to access the SRID table. 
The author created two shapefiles created under QGIS for the grid buffer zone which are provided in Figure 15. One was 100 square meters and the other was 25 square meters, which is a quarter of the original area. All the shapefiles were loaded in the geodatabase.

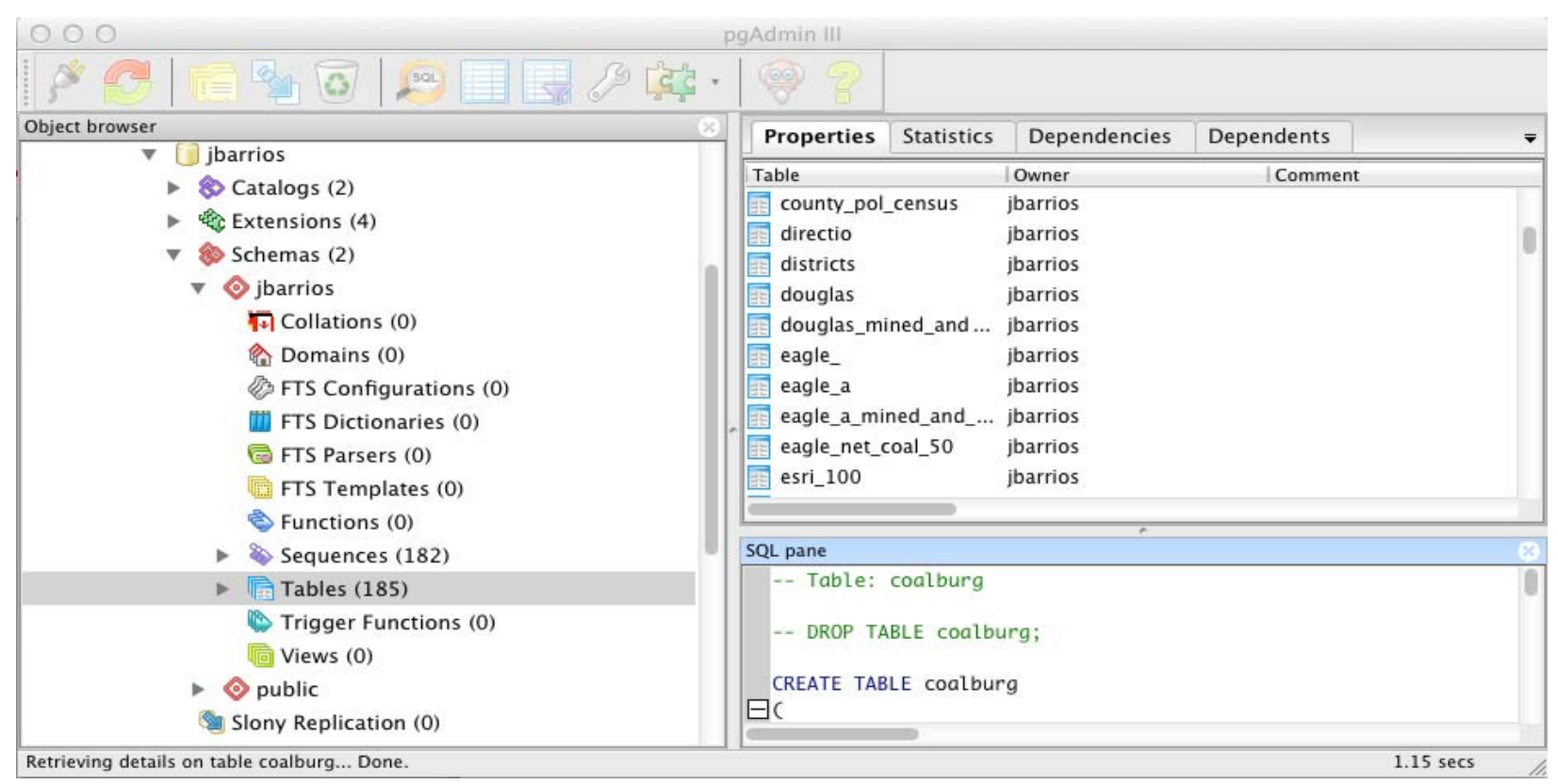

Figure 15 pgAdmin 3 Interface

\section{Volume Calculation}

The volume was calculated using the information from the table under the spatial database and the area generated by the grid. An average of the coal thickness is provided as part of the coal seam table. The calculation utilized the following formula.

Where avgthk6 has United States customary unit (feet)

Calculated area is in meters inherited by the projection system (Universal Transversal Mercator Coordinate System (UTM) 


\section{Results}

The following tables are the results of the analysis at the Macroscopic (Level I), Mesoscopic (Level II) and Microscopic (Level III) including constraints at each level. Included in the table is the processing time recorded at the geodatabase level. Since the dataset are big the researcher wanted to keep the processing time for reference among all the processing times. Figure 16 demonstrates how water bodies, gas wells, urban areas and populated areas shape the final grid.

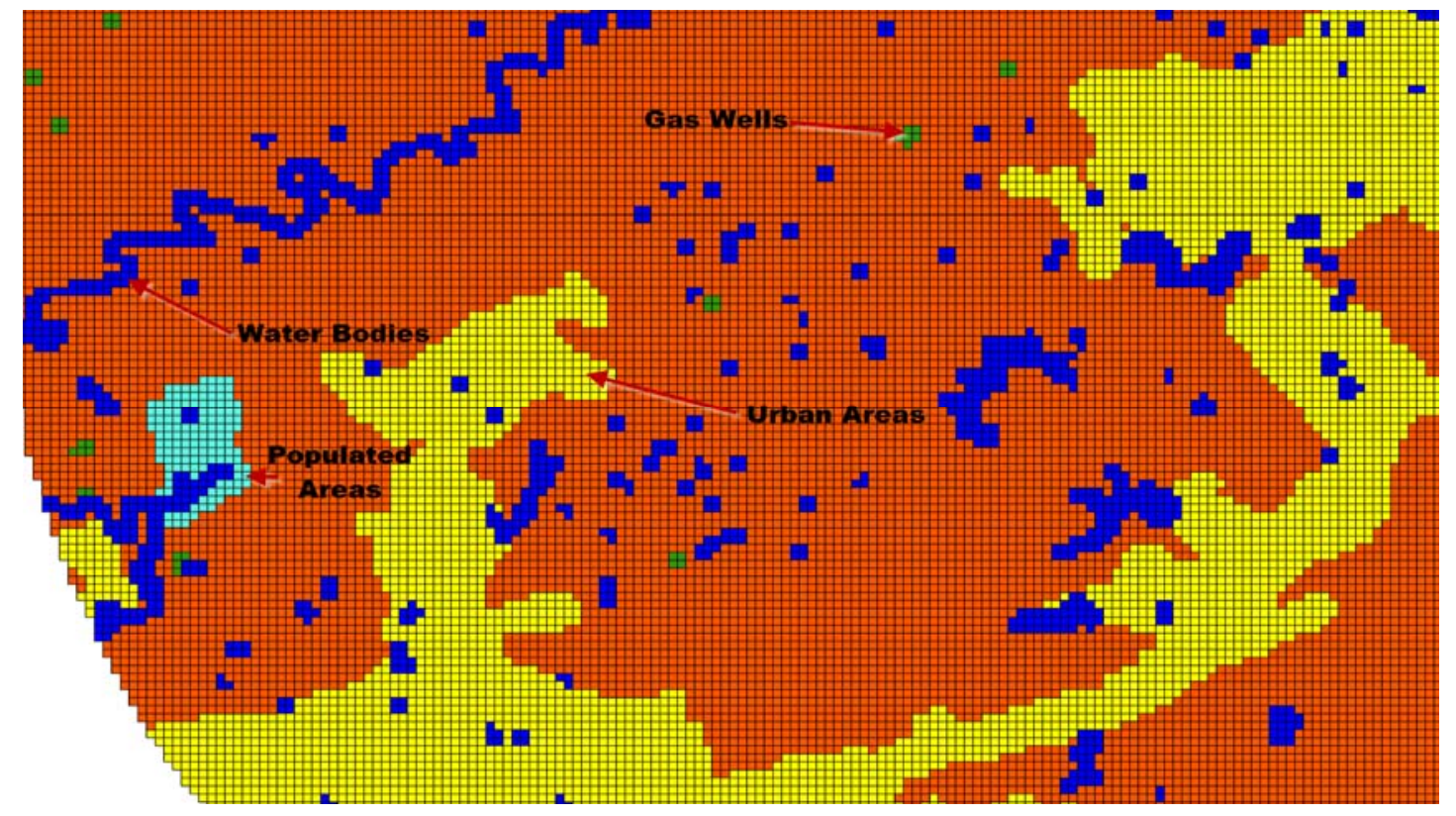

Figure 16 Level II Visualization

Table 6 Shows the results of the geospatial analysis at the Macroscopic Level I scale.

\section{Macroscopic Analysis (Level I)}

Total Grid Cell Count Corridor $=252,471$

Total Grid Cell Count After Constraints $=221,350$

Constraint Factors

Object Count

Grid Cell Count

\begin{tabular}{|l|c|c|}
\hline Water Bodies & 2,890 & 10,004 \\
\hline Parks & 6 & 133 \\
\hline
\end{tabular}




\begin{tabular}{|l|c|c|}
\hline Populated Areas & 43,027 Houses & \\
& 88,517 People & \\
& 4 & 8,544 \\
\hline Urban Areas & 2,813 & 10,520 \\
\hline Oil and Gas Wells & 8 Segments & 1,920 \\
\hline
\end{tabular}

Table 6 Constraint Factors Macroscopic Analysis (Level I)

Table 7 reveals the number of grid affected by the constraint factors at the Mesoscopic Level II.

Mesoscopic Analysis (Level II)

Total Grid Cell Count Corridor $=57,546$

Total Grid Cell Count After Constraints $=51,202$

\begin{tabular}{|l|c|c|}
\hline Constraint Factors & Object Count & Grid Cell Count \\
\hline Water Bodies & 190 & 1,427 \\
\hline Parks & 0 & 0 \\
\hline Population & 11,415 Houses & NA \\
& 23,882 People & NA \\
\hline Urban Areas & 3 & 591 \\
\hline Oil and Gas Wells & 662 & 760 \\
\hline Pipe Line & 6 Segments & 57 \\
\hline
\end{tabular}

Table 7 Constraint Factors Mesoscopic Analysis (Level II)

Table 8 tells the box count of objects affected by the constraint factors at the Mesoscopic Level II.

Microscopic Analysis (Level III) 
Total Grid Cell Count Corridor $=88,745$

Total Grid Cell Count After Constraints $=85,915$

Constraint Factors

Object Count

Grid Cell Count

\begin{tabular}{l|cc|}
\hline Water Bodies & 190 & 2,155 \\
Parks & 0 & 0 \\
Populated Areas & 4,626 Houses \\
Urban Areas & 9,978 People & \\
Oil and Gas Wells & 2 & 1,086 \\
Pipe Line & 104 & 2,728 \\
\hline
\end{tabular}

Note: The Populated Area analysis cannot be obtained because the data is aggregated at the census block.

Table 8 Constraint Factors Microscopic Analysis (Level III)

Table 9 illustrates the complete analysis including Level I, Level II and Level III volume for all possible coal seams that can be surface mined.

\begin{tabular}{|l|l|l|l|l|} 
Coal Seam & Formation & $\begin{array}{l}\text { Level I } \\
\text { Volume }\end{array}$ & $\begin{array}{l}\text { Level II } \\
\text { Volume }\end{array}$ & $\begin{array}{l}\text { Level III } \\
\text { Volume }\end{array}$ \\
\hline $\begin{array}{l}\text { Number_6 } \\
\text { Upper_5 }\end{array}$ & Allegheny & $\mathbf{1 , 5 3 6 , 0 6 2}$ & $\mathbf{7 8 , 4 9 0}$ & $\mathbf{3 7 , 2 5 5}$ \\
\hline $\begin{array}{l}\text { Number_5 } \\
\text { Little_5 }\end{array}$ & Allegheny & $\mathbf{6 , 2 8 4 , 3 9 2}$ & $\mathbf{6 6 0 , 8 2 9}$ & $\mathbf{3 0 6 , 5 8 4}$ \\
Stockton_A & Kllegheny & $\mathbf{5 , 0 6 1 , 9 9 0}$ & $\mathbf{3 4 1 , 8 4 6}$ & $\mathbf{1 5 2 , 0 3 2}$ \\
Stockton_Rider & Kanawha & $\mathbf{3 , 9 4 7 , 2 1 1}$ & $\mathbf{1 6 6}$ & Null \\
Stockton & Kanawha & $\mathbf{2 3 , 7 0 9 , 5 6 9}$ & $\mathbf{7 1 4 , 7 1 7}$ & $\mathbf{2 9 8 , 2 4 0}$ \\
Coalburg & Kanawha & $\mathbf{1 4 0 , 7 2 0 , 0 9 2}$ & $\mathbf{1 0 , 9 6 9 , 9 0 0}$ & $\mathbf{4 , 1 6 8 , 3 2 9}$ \\
Little_Coalburg & Kanawha & $\mathbf{5 9 , 0 0 3 , 6 0 8}$ & $\mathbf{7 , 5 3 7 , 9 1 4}$ & $\mathbf{3 , 0 5 3 , 2 4 9}$ \\
Winifrede & Kanawha & $\mathbf{2 7 , 1 5 2 , 5 3 2}$ & $\mathbf{4 , 4 3 1 , 2 0 0}$ & $\mathbf{1 , 1 6 7 , 7 9 3}$ \\
\hline
\end{tabular}




\begin{tabular}{|l|l|l|l|l}
\hline Chilton_Rider & Kanawha & $105,317,906$ & $13,370,108$ & \\
Chilton_A & Kanawha & $43,956,096$ & $10,221,303$ & \\
Chilton & Kanawha & $71,125,350$ & $15,298,416$ & \\
\hline Little_Chilton & Kanawha & $202,314,253$ & $29,893,291$ & \\
\cline { 2 - 4 } & Total m3 & $713,548,646$ & $95,421,858$ & $10,162,124$ \\
\hline
\end{tabular}

Table 9 Macroscopic, Mesoscopic, and Microscopic Volumetric Analyses

Table 10 tells the monetary value at different levels of the possible coal seams, and the estimated cost of the construction. As we can observe Microscopic Level III analysis validates the Code of Federal Regulations 30, Mineral Resources (30 CFR § 213.5) for incidental coal extraction.

\begin{tabular}{|c|c|c|c|}
\hline \multirow[t]{2}{*}{ Coal } & Level I & Level II & Level III \\
\hline & Macroscopic & Mesoscopic & Microscopic \\
\hline Total & $713,548,646$ & $95,421,858$ & $10,162,124$ \\
\hline $\begin{array}{l}\text { Recovery Rate } 65 \% \\
\text { of total coal volume }\end{array}$ & $463,806,620$ & $62,024,208$ & $6,605,381$ \\
\hline Weigh (Kg) & $613,616,158$ & $82,058,027$ & $8,738,919$ \\
\hline $\begin{array}{l}\text { Weight } \\
\text { short ton }\end{array}$ & $\mathbf{8 1 1 , 8 1 4 , 1 7 7}$ & $74,443,042$ & 7,927,947 \\
\hline \multicolumn{4}{|c|}{ Price per short ton $\$ 66.15$ Dollars } \\
\hline $\begin{array}{l}\text { Estimated Value of } \\
\text { Coal }\end{array}$ & $\$ 53,701,507,822$ & $\$ 4,924,407,228$ & $\$ 524,433,694$ \\
\hline Cost of Construction & \multicolumn{2}{|c|}{$\$ 1,500,000,000-\$ 2,300,000,000$} & \\
\hline
\end{tabular}

Table 10 Monetary Value of Coal

\section{Notes}

Short Ton 0.9072 Metric Ton source http://www.ndc.iwr.usace.army.mil/metric.htm.

Coal density $(\rho) 1.323 \mathrm{~kg} / \mathrm{m} 3$ (U.S. Departament of the Interior, 1982).

Price per short ton as November 30, 2012 http://www.eia.gov/coal/news markets/.

For this specific case study, the future value of coal is likely to increase by 1.4 percent per year (U.S. Energy Information Administration, 2013). The varitaion in coal prices are described in 
Table 17 in which a percentage evaluation clarifies the disparity. Using 2012 as a benchmark, the change between 2011 to 2012 shows a 15 percent reduction in the price of coal, while no significant increase in the price is demonstrated from 2010 to 2013.

\section{Coal Volume}

Table 11 displays the total amount of volume that can be extracted from the area of interest at different levels. The coal/volume ratio is less than 0.05 percent of the maximum extractable volume. This relative amount will increase at Level III to almost 0.08 percent.

\begin{tabular}{lll}
\hline & Total Volume & Coal Volume \\
\hline Level I Macroscopic & $951,903,118,519$ & $434,109,712$ \\
Level II Mesoscopic & $38,517,776,815$ & $95,421,858$ \\
Level III Microscopic & $1,433,223,838$ & $10,162,124$ \\
\hline & Table 11 Coal Volume &
\end{tabular}

\section{Coal Value}

Figure 17 and table 12 illustrates the past four years' values of coal and the cost in the Public Private Partnership.

\begin{tabular}{lllr}
\hline Estimated Value of Coal & Macroscopic & Mesoscopic & Microscopic \\
\hline Year 2013 & $53,701,507,821$ & $4,924,407,228$ & $524,433,694$ \\
Year 2012 & $51,850,571,497$ & $4,754,677,092$ & $506,357,974$ \\
Year 2011 & $63,443,277,948$ & $5,817,723,732$ & $619,569,058$ \\
Year 2010 & $53,977,524,642$ & $4,949,717,862$ & $527,129,196$ \\
\hline
\end{tabular}

Table 12 Value of Coal 2010-2013

Sources (State of West Virginia, 2012), (U.S. Energy Information Administration, 2013)

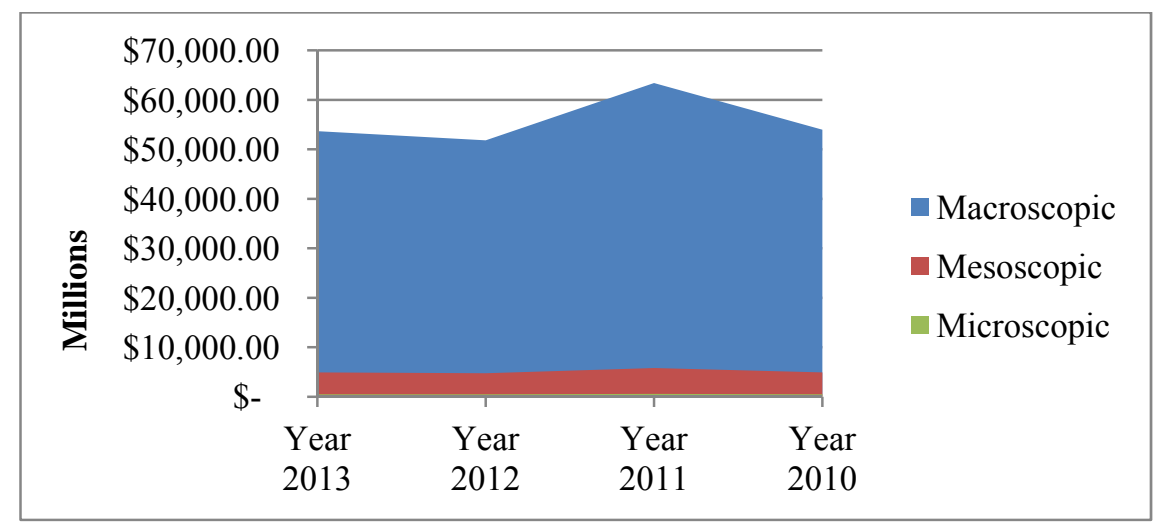


Figure 17 Value of Coal 


\section{Chapter 5}

\section{Conclusions}

The goal of this research was to develop a methodology to quantify the availability of natural resources, particularly coal, along predetermined roadway alignments. This chapter addresses: 1. Research Findings, 2. Research Contributions, 3. Research Limitations, and 4. Recommendations for Future Research.

\section{Research Findings}

This research explored the methodology for natural resource extraction to offset the cost of building a highway. During the development of the research framework, several key components were addressed such as environmental and technical. These findings are comprised of legal and technical segments. The technical segment is divided in two additional components which are software platform related and data related.

\section{Legal}

Legal ramifications are important to understand and to address. There is a perception that Public Private Partnerships are a type of privatization and only benefit specific groups. The author of this research found that Public Private Partnerships can be deployed to benefit the public; such resources are a new stream of limited resources for the development of projects. This process should have a clearly defined objective and utilize a transparent method. Historically, the extraction of raw materials to use for the construction or selling has been done in the United 
States prior to this case study (Miller, 2000). Now, federal law has several constraints for the use of this practice (Judith W. Wegner, 1987). Two important issues regarding this case study are evident:

\section{Environmental}

The environmental constraints are legal issues and essential to be resolved for the development of any project. The King Coal Highway has two different tiers regarding the environment.

o Post Mined Land Use

The segment for the Red-Jacket is a post mined land use area used to bring accessibility to the area. The owner of the land donated the area for the construction of a school, roads and other facilities, such as water pipelines. In this case, the application of the partnership was after the permit was issued. A modification was allowed by the West Virginia Department of Transportation to leave a road bed instead of bringing the land back to the original contour.

o Mining permits

During the interview with Dr. Castle (2011), he addressed that “...the current federal administration will never give new mining permits." This situation will generate a significant problem for the future of the road and the Public Private Partnership using coal. The Environmental Protection Agency will neither authorize new permits nor the modification of existing permits. This reality definitively affects the potential for Public Private Partnerships with the other road segments. 


\section{Labor}

A clear definition of the work done during the surface mining at the King Coal Highway was not developed. From the coal company point of view, the non-union workers are just moving soil; from the union workers' point of view, they are mining. This issue has implications regarding the Davis Bacon Act (United States Department of Labor), and will impact the construction cost. The dispute between unions and coal companies is currently being addressed in the court rooms (Castle, 2011).

\section{Legal Summary}

From the legal standpoint, Public Private Partnerships are agreements between the public and private sector; however, the contract usually is unique, by nature, among the stakeholders. This uniqueness can be a win-win situation for the participants; this is the final goal, as it can be seen in the King Coal Highway project. This sui generis or unique approach can work on the solution for specific situations, but several problems dealing with these strategic partnerships can rise, such as:

- The analysis for the projects can take time and resources that may not be available at the beginning of the project.

- The legal experience in developing the contract is important.

- A lesson learned in the King Coal Highway is to keep the agreement simple; that agreement is only 28 pages.

\section{Technical}

The technical segment can be addressed in two components. 


\section{Software Platform}

During the development of the Open Source Geospatial Database, several issues were identified from the data structure and the proprietary components among the software platform, such as interoperability, geospatial database, and queries.

o Interoperability Environmental Systems Research Institute software has proprietary naming for the geospatial library structures; this naming convention generated a conflict with the other open source software (i.e., R statistical analysis and Quantum Lisboan). There are three different forms to load data to the geospatial database; this situation can generate conflicts with the library used to read the projections.

\section{o Geospatial Database}

The spatial instruction ST_Contains generates a false reading with polygon/ line string if the line string is not completely inside the polygon. Also, if the relationship between shapes is not well defined using the above instructions, the spatial geodatabase can generate a false reading at the PostGIS log. The ST_Contains relationship between populated areas and grid generated more than 73,000 errors in a minute.

\section{o Structured Query Language (SQL)}

During the development of the Structured Query Language (SQL) statement based on the equation one, problems occurred because of differences in geometric types (i.e., point and polygons). The proper command should be ST_Disjoint that 
gives information about Boolean algebra and spatial correlation. In mathematical terms, (Universidad Politécnica de Valencia, 2011):

\section{a. Disjoint $(\mathbf{b}) \ll-» \mathbf{a} \cap \mathbf{b}=\varnothing$}

The spatial database was unable to process the command from the library.

\section{Data}

o Availability

Availability has several implications for this research. The West Virginia

Geological \& Economic Survey group has been working on the conversion of the data, bringing another variable to the model.

- The temporal resolution of the data. In the development of the case study, time is a constraint that has a different effect, especially in the economic side regarding construction cost and future value of the coal for the whole development of the project.

o Accuracy

Further research needs to be done to measure the accuracy of the data. Taking as a reference the microscopic analysis, the Delta $(\Delta)$ between microscopic and macroscopic is 3.04 percent in an area of one mile from the center line of the alignment. The Delta $(\Delta)$ between the Mesoscopic and the Microscopic is only 0.45 percent. These results only demonstrate the area of interest which results in a mile buffer from the center line for the three levels. Other analyses are needed for bigger areas, taking in consideration more constraints. 


\section{Research Contributions}

This research demonstrates that Public Private Partnerships (PPPs) for highway constructions can use coal to offset the cost, but several legal constraints must be taken in consideration before such endeavor (institutional and environmental). This kind of natural resource extraction as a derivative from construction has been in place for a long time, but a framework for evaluation was not in place. This geospatial approach contributes in many ways to the academic community, as well as State and Federal agencies.

First, this research contributes by developing a methodology to assess coal availability using geospatial sciences. This is achieved by creating geospatial models to represent a preselected area for the different level of analyses (i.e., macroscopic, mesoscopic and microscopic) by using different datasets, representations and institutional knowledge from Environmental Impact Statement (EIS) process and coal extraction. Understanding how these critical components constraints factors interact is a critical issue for the representation and incorporation in geospatial data processing using open source platforms.

The second contribution of this research is the Public Private Partnership's legal framework used for natural resource coal extraction and labor laws (Davis Bacon Law and Chapter 21 Amendment 5 of the West Virginia State Code). These studies demonstrate that the coal assessment should be taken in at the preliminary engineering because the possibility of coal extraction should be determined before all the other parts of the Environmental Impact Statement (EIS). A common practice is that the West Virginia Department of Transportation 
tries to avoid coal because if the road passes through the coal reserves, the State would be required to pay a fair market value of the coal.

Another component of this new legal framework is the use of coal as a barter exchange tool instead of money. With this approach, the temporal effect of the coal value can be taken into consideration. Usually construction of a road takes years. As stated in this research, the future value of coal is expected to increase; therefore, the future value of the money will be tied to the spot coal market.

The third contribution of this research is the development of a data system that can accommodate large datasets (scalable). The data flow layout was designed be used in a flexible environment. Coal shapefiles (Environmental Systems Research Institute proprietary file) and other data sets are large. The processing of the data to generate information and subsequently knowledge can take days and computer power. The technique developed allows a robust and repeatable approach for the data mining.

\section{Research Limitations}

The research limitations can be a categorized in one general area related to data. This area includes the ways in which collection, conversion, and preprocessing of data have an impact in the final framework.

o West Virginia is in the process of converting coal seams which is a computer and labor intensive process. Data availability is dependent on the West Virginia Geological and Economic Survey group. More detailed data can be created with core drillings; this data processing is needed for the Level III -Microscopic Analysis. 
o In this research the surface ownership was simple, but if the landowners involved a group of people, the parcel data collection and conversion can be a laborious and difficult task, because the data is usually in paper format for rural areas.

o During this research, one set of data was created for the research because of data availability.

The data examination illustrated that the models are limited in supporting fine data, in particular, small grid from closer or distance views. However, the research demonstrated that the microscopic analysis at the data base level was capable of processing the data at a fine resolution. The preprocessing was unavailable to create the grid under open software.

\section{Recommendations for future research}

Research on this Geospatial approach for Public Private Partnerships (PPPs) requires future research. The PPP is a viable funding source for projects. Public Private Partnerships need to be simple and clear to achieve results. The development of a mechanism to follow and evaluate existing PPPs is needed to learn from past experiences. There is a movement to change long term evaluations ( 20 years) to a more midterm evaluation ( 10 years). This change of temporal analysis can change the whole interaction in public-private agreements, especially in road constructions.

The use of geospatial information for decision making is a powerful tool in the development of models for the assessments or return on the investment. The first step involves examining the possibility of the use of a new analytical tool for natural resources. In this specific case coal was the natural resource, but other natural resources can be used. Applying geospatial techniques for 
other locations and bigger areas are needed for adjusting the model for best fitting possible. The author recommends using open source data and software for the new development of the tools. Open Geospatial Consortium Standards allows the knowhow of the routines and the possibility of replication of the processes under a controlled environment. Under this concept, other software may be used, platforms such as R-Geo library, in the current architecture.

The ordinary Voronoi diagram defined on a plane with Euclidian distance is commonly used for spatial analysis as the first approximation of areas (Fotheringham \& Rogerson, 2009). A future research project should develop a tool to choose optimal roadway alignment to maximize coal extraction. Figure 17 demonstrates the possible usage of Voronoi Diagrams.

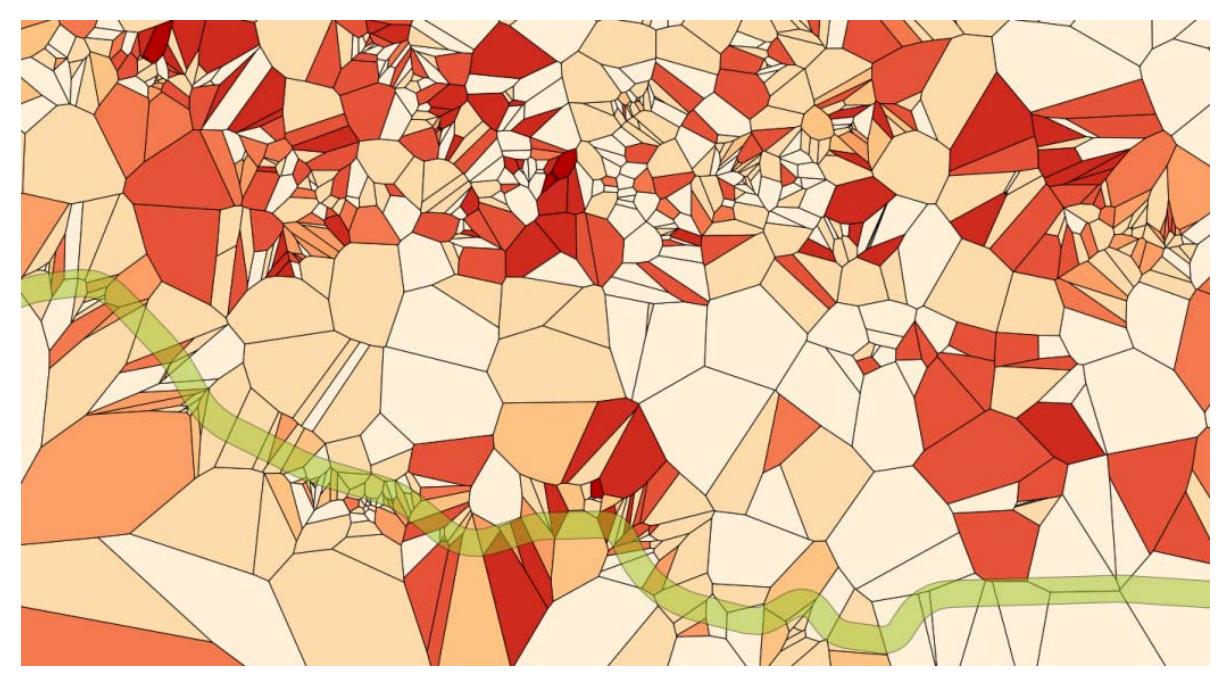

Figure 18 Voronoi Diagram

Figure 18 illustrates the how road alignment can take coal in consideration for the road alignment. 


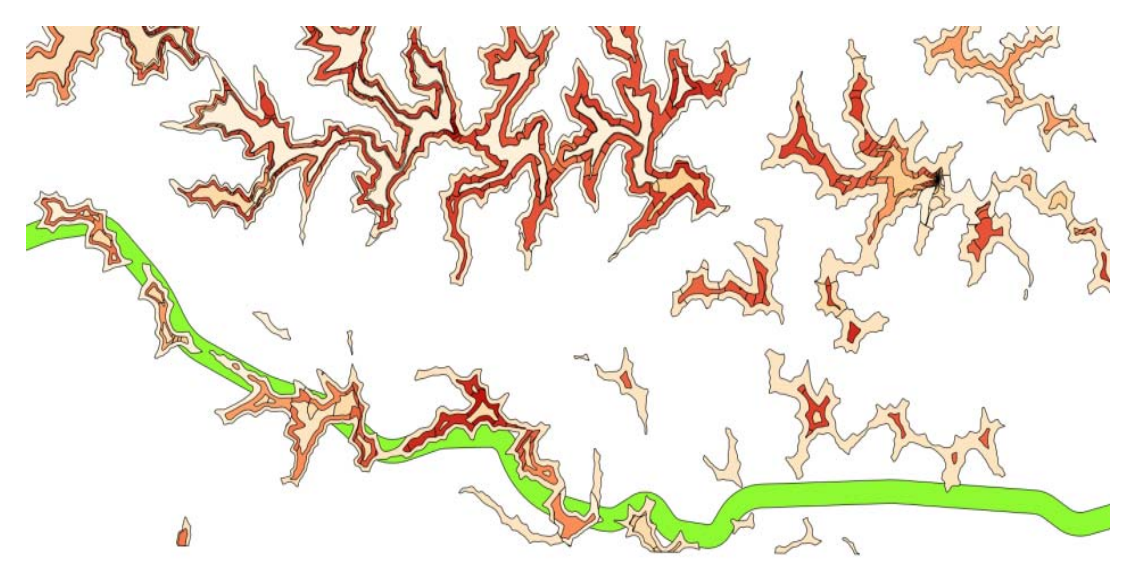

Figure 19 Best Possible Alignment 


\section{Flow Processes}

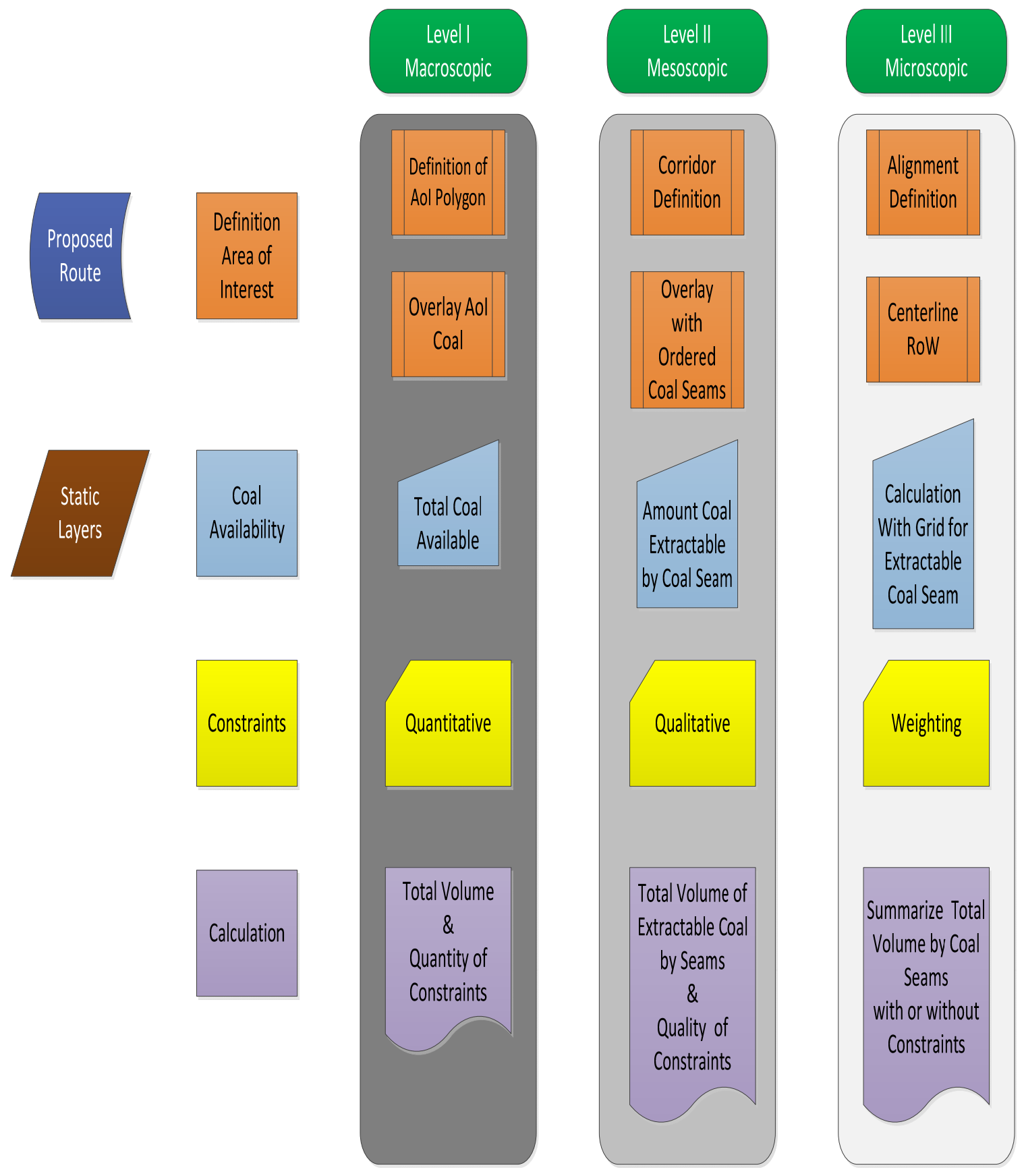

Figure 20 Proposed Flow Process 


\section{Availability Process}

Volumetric Assessment

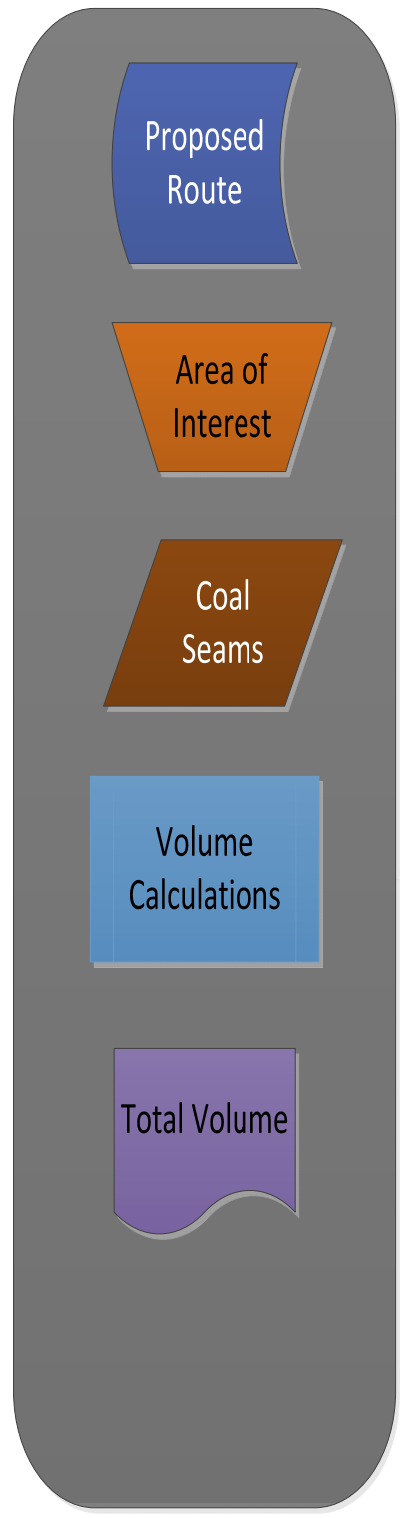

\section{Conditional Process}

Boolean Algebra

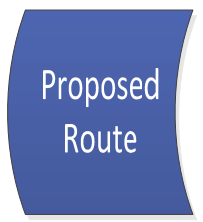

Area of

Interest

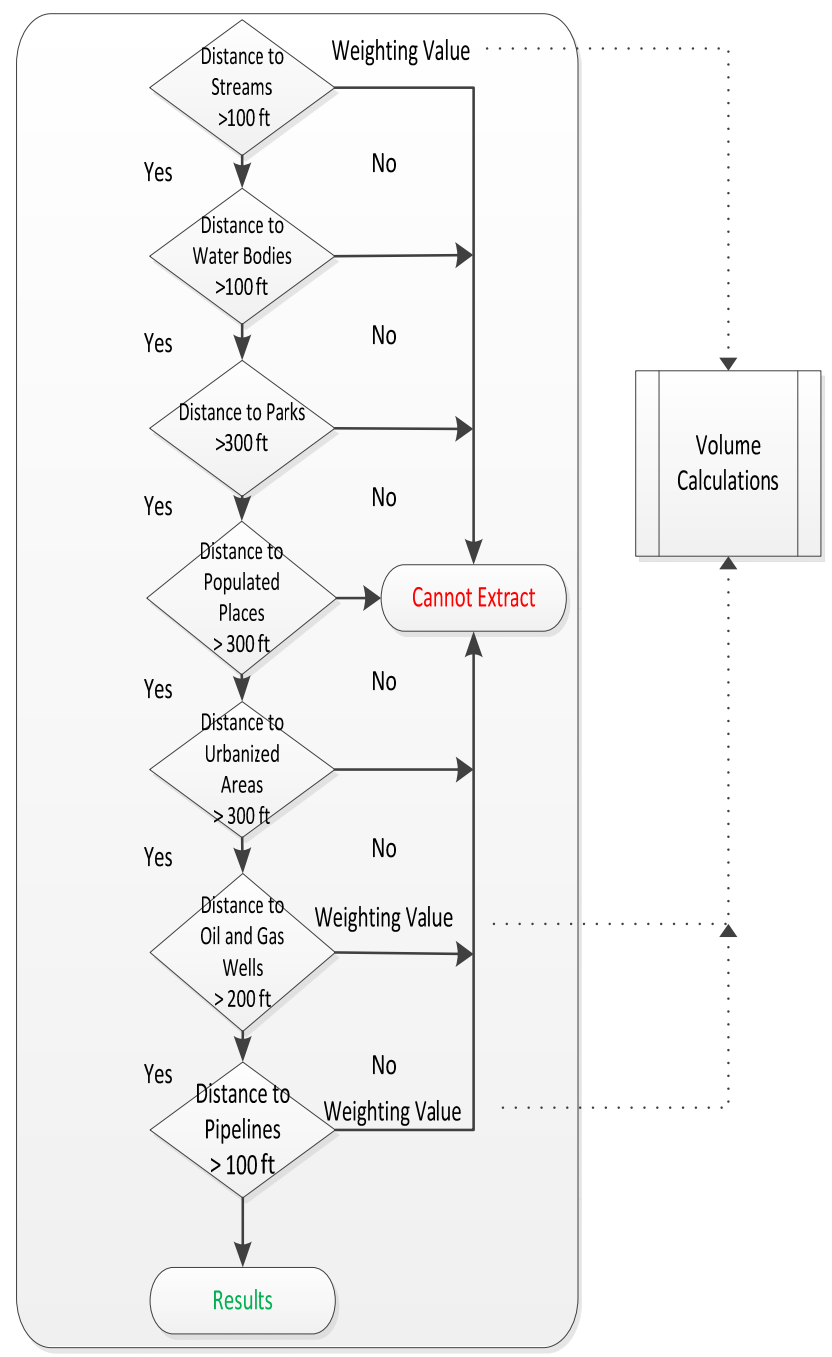

Figure 21 Flow Process 


\section{Static Layers}

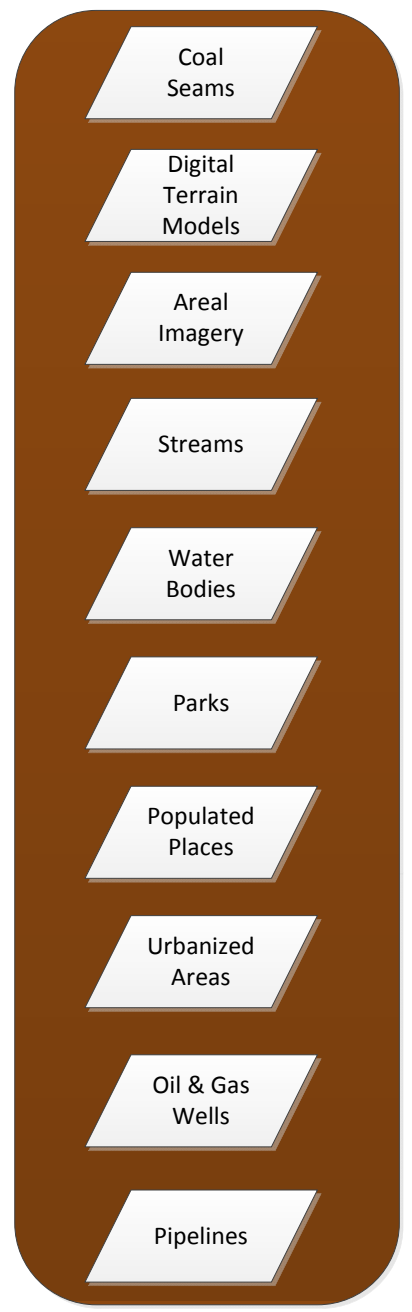

Coal Seams are generated by the WV Geological and Economic Survey (WVGES) Group dependent on the WV Department of Commerce. The WVGES develops a Coal Bed Mapping Project (CBMP) with the objective of creating a Geographic Information System-based inventory of coal. All the information is available to general public. http://www.wvgs.wvnet.edu/www/coal/cbmp/goal.html

The DEM are an array of elevation from ground positions at 3 meters. They are a part of the Statewide Addressing and Mapping Board (SAMB) final product. SAMB is hosted at the WV Department of Homeland Security. The data was collected in 2003. Maximum Accuracy +-10 Feet.

http://wvgis.wvu.edu/data/dataset.php?ID=261

There are several sources of imagery and for this case a 0.60 meters dataset from the SAMB is used. They are a part of the Statewide Addressing and Mapping Board (SAMB) final product. SAMB is hosted at the WV Department of Homeland Security. The data was collected in 2003.

http://wvgis.wvu.edu/data/dataset.php?ID=261

There are several sources for this dataset. For the current analysis the Statewide Addressing and Mapping Project is used (2003 SAMB). This data was processed by the WVU GIS Tech center, and can be access at http://wvgis.wvu.edu/data/dataset.php?ID=265.

There are several sources for this dataset. For the current analysis the Statewide Addressing and Mapping Project is used (2003 SAMB) This data was processed by the WVU GIS Tech center and derived from the USGS National Hydrological Dataset (NHD) and Digital Line Graphs (DLG). It can be access at http://wvgis.wvu.edu/data/dataset.php?ID=204.

There are several sources for this dataset. For the current Analysis a Census 2010 dataset was utilized. US Census Bureau generates a GIS-based system for public usage. Also the data can be accessed at the WVU GIS Tech Center http://wvgis.wvu.edu/data/ dataset.php?ID=203

There are several sources for this dataset. For the current Analysis a Census 2010 dataset was utilized using Tiger Data sets. US Census Bureau generates a GIS-based system for public usage. http://www.census.gov/geo/www/tiger/shp.html

There are several sources for this datasets. For the current Analysis a Census 2010 dataset was utilized using Tiger Line Files. US Census Bureau generates a GIS-based system for public usage. http://www.census.gov/geo/www/tiger/shp.html

This dataset is created by the West Virginia Department of Environmental Protection Office of Oil and Gas (DEP O\&G). DEP O\&G is responsible to monitoring and regulating all parts of Oil and Gas wells across the state. http://www.dep.wv.gov/oil-and-gas/Pages/ default.aspx

This dataset is proprietary from the Columbia Energy Midstream. The data was converted from a PDF file to an ESRI shapefile specifically for the analysis.

Figure 22 Layer Description 


\section{Appendices}




\section{Public Private Partnerships Background}

\section{History}

Garvin, in America's Infrastructure Strategy: Drawing on History to Guide the Future, (2007), extensively addresses the Public Private Partnership (PPP) history in America. The approach taken during the Great Depression by President Franklin D. Roosevelt regarding infrastructure was more of a social policy rather than an economic policy. The main focus was job creation for the unemployed. Since then, the perspective for infrastructure has been modified to create an engine for economic development. At the end of the Great Depression came World War II, which dictated America's political, economic, and social structure until the end of the war in the 1940s (Garvin, 2007).

The United States had almost twenty years of continuous changes, which created a new political and economic environment. The Cold War began right after the end of World War II, which prompted an unprecedented focus on national defense. According to Garvin, the most significant outcome of this period was the Interstate Highway System. The strategy used to build this $\$ 40$ billion national security and economic platform, and the changes in federal procurement requirements made it almost impossible to develop Public Private Partnerships (PPP) in infrastructure projects (Garvin, 2007).

In the late 1980s, a new trend developed to review the use of Public Private Partnerships (PPP) as possible solutions to building, repairing and maintaining aging public infrastructure, with a focus on transportation. The movement was initiated in the United States with the development of the Special Experimental Project No. 14 - Innovative Contracting (U.S. Departament of 
Transportation Federal Highway Administration, n.d.). In the 1990s, the Intermodal Surface Transportation Efficiency Act (ISTEA) (U.S. Departament of Transportation Research and Innovative Technology Administration, 1991) developed the blueprint for private investment in surface transportation. This act allowed tolls to a larger degree on federal facilities. For the first time, the private sector was allowed to operate toll facilities (Garvin, 2007). This movement gave states flexibility to utilize new and innovative financing methods. Participation from the private sector in non-traditional areas of a project with risks and rewards shared in new investment ways such as tolls or lending money for the construction were sought (U.S. Departament of Transportation, 2004). Later transportation acts, including the Safe, Accountable, Flexible, Efficient Transportation Equity Act: A Legacy for Users (SAFETEALU), followed the same approach. This movement has decelerated, however, because of the uncertainties regarding federal transportation legislation (Parsons, 2010). This legislation can be easily differentiated by political parties' points of view, the Republican Party point of view fostered PPPs and the Democrat Party avoided the possible deployment of PPPs. House Report 108-243 (2003), accompanying the FY 2004 Department of Transportation Appropriations Act, requested a report from the U.S. Department of Transportation (DOT) identifying the impediments to the formation of large, capital-intensive highway and transit projects involving Public Private Partnerships.

Political turmoil started with the United States House of Representatives Committee on Transportation and Infrastructure, which sent a letter to the nation's governors regarding Public Private Partnerships (PPPs). The letter was intended to "Strongly discourage you from entering into Public Private Partnership agreements that are not in the long-term public interest in a safe 
integrated national transportation system that can meet the needs of the $21^{\text {st }}$ Century" (Innovation Briefs , 2007).

A year later, under the Bush administration, the use of Public Private Partnerships (PPPs) to finance the public infrastructure was encouraged as evidenced in the February 25, 2008 speech given by the United States Secretary of Transportation, Mary Peters. At a hearing before the Department of Transportation, Secretary Peters advocated market-based support and management of roads. She commended California and Pennsylvania for their approach in applying private capital through PPPs. Peters stated, "America's transportation system can be better and my goal is to clear federal obstacles to innovation and investment so you can make that happen" (Federal Highway Administration, 2008).

David B. Horner, former Deputy Assistant Secretary for Transportation Policy for the United States Department of Transportation, further lent support for governmental policies regarding Public Private Partnerships (PPPs), Horner stated, "Unlike in Europe, in the U.S. there is not a strong national government that can dictate a new policy. In the UK, the audience of powerful decision makers is quite small - you only need to convince a handful of senior civil servants of the merits of a policy and it's done" (Ganz, 2009). According to Ganz's review (2009), the essence of Horner's comments compared the United States government's role in policy making to that of the United Kingdom. The review maintained that policy development, including considerations for financing the United States' system for highway development, was impeded by a labor intensive policy development process. 


\section{Legal Definition Public Private Partnerships}

Table 13 exhibits the different legal definitions from important worldwide participants in Public

Private Partnerships (PPPs). In most of the definitions the key words are agreements,

arrangements or cooperation among the public sector and the service provider.

\begin{tabular}{|c|c|}
\hline Source & Definition \\
\hline HM Treasury & $\begin{array}{l}\text { PPPs are arrangements typified by joint working between the public and } \\
\text { private sector. In the broadest sense, PPPs can cover all types of collaboration } \\
\text { across the interface between the public and private sectors to deliver policies, } \\
\text { services and infrastructure. Where delivery of public services involves private } \\
\text { sector investment in infrastructure, the most common form of PPP is the } \\
\text { Private Finance Initiative (PFI). (HM Treasury) }\end{array}$ \\
\hline World Bank & $\begin{array}{l}\text { There is no one widely accepted definition of PPP. Broadly, PPP refers to } \\
\text { arrangements between the public and private sectors whereby part of the } \\
\text { services or works that fall under the responsibilities of the public sector are } \\
\text { provided by the private sector, with clear agreement on shared objectives for } \\
\text { delivery of public infrastructure and/ or public services. (World Bank, 2001) }\end{array}$ \\
\hline $\begin{array}{l}\text { European } \\
\text { Commission }\end{array}$ & $\begin{array}{l}\text { A PPP is a partnership between the public sector and the private sector for the } \\
\text { purpose of delivering a project or a service traditionally provided by the } \\
\text { public sector. (European Commission, 2004) }\end{array}$ \\
\hline $\begin{array}{l}\text { The Canadian } \\
\text { Council for } \\
\text { Public-Private }\end{array}$ & $\begin{array}{l}\text { A PPP is a cooperative venture between the public and private sectors, built } \\
\text { on the expertise of each partner that best meets clearly defined public needs } \\
\text { through the appropriate allocation of resources, risks and rewards. (The } \\
\text { Canadian Council for Public-Private Partnerships , 2011) }\end{array}$ \\
\hline $\begin{array}{l}\text { The National } \\
\text { Council for } \\
\text { Public Private } \\
\text { Partnerships }\end{array}$ & $\begin{array}{l}\text { A PPP is a contractual agreement between a public agency (federal, state or } \\
\text { local) and a private sector entity. Through this agreement, the skills and assets } \\
\text { of each sector (public and private) are shared in delivering a service or facility } \\
\text { for the use of the general public. In addition to the sharing of resources, each } \\
\text { party shares in the risks and rewards potential in the delivery of the service } \\
\text { and/or facility. (The National Council for Public Private Partnerships) }\end{array}$ \\
\hline US DOT & $\begin{array}{l}\text { A PPP is a contractual agreement formed between public and private sector } \\
\text { partners, which allow more private sector participation than is traditional. The } \\
\text { agreements usually involve a government agency contracting with a private } \\
\text { company to renovate, construct, operate, maintain, and/or manage a facility or } \\
\text { system. While the public sector usually retains ownership in the facility or } \\
\text { system, the private party will be given additional decision rights in } \\
\text { determining how the project or task will be completed. (U.S. Departament of } \\
\text { Transportation, 2004) }\end{array}$ \\
\hline
\end{tabular}

Table 13 Public Private Partnerships 


\section{Types of Public Private Partnerships}

Literature identifies different types of highway Private Public Partnerships (Mallet, 2008; Transportation Infrastructure Finance and Innovation Act of 1998, 23 U.S.C. § 181-189 (TIFIA); National Cooperative Highway Research Program, 2009). The most important difference is between new or existing highways (National Cooperative Highway Research Program, 2009). The National Cooperative Highway Research Program from the Transporation Research Board (2009) identifies the following types of private partnerships:

1. Brownfields and Greenfields

The operation and maintenance of an existing infrastructure is typically referred as a "brownfield" project. The development and construction of a new facility is referred to as a "greenfield" project. According to Mallet (2008) these two types of highway Public Private Partnerships generate the most controversy. The controversy is based on the lack of transparency of the agreements (Mallet, 2008).

\section{Innovative Contracting Techniques}

According to the National Cooperative Highway program report (2009), contracting techniques can be divided into two general types because of the lack of transparency. The first type is innovative contracting techniques that involve non-traditional forms of agreements. The second contracting type is innovative financial techniques and involves some form of private project financing.

\section{a. Design to Build (D-B)}

The design and construction procurement is combined into one fixed contract with one point of contact that has the responsibility of designing and building the facility (Kwak, Chih, \& Ibbs, 
2009). The point of contact can be one company or a holding of companies and the entity assumes the risk of the project. According to the authors, the risks can be categorized as: political, financial, constructions, operation and maintenance, and market and revenue.

\section{b. Design Build Operate Maintain (DBOM)}

With a Design Build Operate Maintain (DBOM) contract, the contractor or holding company is responsible for the operation/maintenance for a well-defined time under a one single contract. The contract meets a set of performance standards approved prior to writing the contract (Kwak et al., 2009). This type of agreement generates a higher set of expectations regarding the quality of services, because the contractor is responsible for operating and maintaining the facilities. The authors maintain that it is in the best interest of the contractor to provide good construction to avoid expensive maintenance and operations.

\section{c. A+B Contracting}

$\mathrm{A}+\mathrm{B}$ contracting is also known as cost plus time procurement. Under this approach, the selection of the bid is associated with the lowest bidder based on (A) the price of the bid and (B) the values associated with the time constraint (Kwak et al., 2009). The main goal under this approach is to obtain a contract based on time, and to associate the risk of the contract with the contract deadline.

\section{d. Construction Manager/General Contractor (CM/GC)}

Under Construction Manager/General Contractor (CM/GC) agreement, the project sponsor hires a design contractor and a building contractor simultaneously; both companies work together during the construction. The project sponsor keeps the control of the project at all times (Kwak et al., 2009). 


\section{e. Construction Manager at Risk}

Under this type of contract, the separation of duties is established at the beginning of the contract. The benefit of this type of project is that the design is in progress at the same time that the negotiations are taking place (Kwak et al., 2009).

\section{Innovative Financing Techniques}

A wide range of private investments and tools are available for the development and financing of Public Private Partnership. The tools are included in the Transportation Infrastructure Finance and Innovation Act of 1998, 23 U.S.C. § 181-189 (TIFIA) financial tools.

\section{a. Design Build Finance Operate (DBFO)}

The Design Build Finance Operate (DBFO) is a variation of the Design Build Operate and Maintain (DBOM) previously described in the contracting techniques. In the case of the DBFO, the contractor finances the project and uses the revenues (tolls or other type of mechanisms) to repay the private or other entities involved in the financing of the project. The DBFO risk is transferred to the contractor for the duration of the agreement. Another variation of the DBOM is the Build Transfer Operate (BTO) agreement. Under this specific contract, the contractor owns the project until the construction is completed. Under both the DBFO and the BTO agreements, the public sponsor will own the facility at the end of the agreement (Transportation Infrastructure Finance and Innovation Act of 1998, 23 U.S.C. § 181-189).

\section{b. Build Operate Transfer (BOT)}

The Build Operate Transfer (BOT) agreement is similar to Design Build Finance Operate (DBFO) scheme, except that the contractor keeps the ownership at all times. The agreement does not require that the facility be returned to the public sector when the useful life of the 
facility has been reached. The important aspect of this type of contract is that the risks and rewards are given to the contractor. These types of agreements are not frequently used in the United States Highway sector (Transportation Infrastructure Finance and Innovation Act of 1998, 23 U.S.C. § 181-189).

\section{c. Long Term Lease Concession (LTC)}

The Long Term Lease Concession (LTLC) is the innovative financing technique receiving the most criticism from the public, mainly because the general perception is that it is a type of privatization of a public asset. With this type of agreement, the concessionaire agrees to pay a direct lump-sum to the public agency in exchange for the right to collect revenue generated from the facility. The total duration of the contract ranges from 25 to 99 years. In recent years, especially in Europe, these types of agreements have been under review. The main issue with the LTLC financing agreement is the time factor. Under the LTLC agreement, the life cycle of the contract is normally 30 years. Stakeholders typically want to review the agreements in 5 or 10 years to certify that the contractor is fulfilling the contract. According to a presentation of Spanish Engineering Professor José Manuel Vassallo, Ph.D., the idea behind this change is that in 10 years many things change in the sector, industry and technology (Vassallo, Baeza, \& Ortega, 2011). Professor Vassallo prompted that these advancements in industry, technology, and other changes show evidence that a review of travel agreements are significant in order to keep pace with the rapid changing world.

\section{Innovative Financing Tools}

A wide range of innovative financial tools are available to support private funding in the private sector. These are enumerated below. In addition to standard financial mechanisms, the private sector can access Transportation Infrastructure Finance and Innovation Act (TIFIA) funds and 
instruments for highway projects. These instruments often are used in combination with traditional financial tools such as bonds.

TIFIA Financing (23 U.S.C $§ 601-609$ ). These types of instruments allow the United States Department of Transportation to support a sponsor of a major transportation project for public or private entities. The main components of the TIFIA are: Traditional grant projects that will not get any financial funding from tolls or other sources and projects that can generate sufficient revenue to support themselves without government assistance. The TIFIA program supports eligible projects in following ways: direct loans, loan guarantees and letters of credits (TIFIA Financing (23 U.S.C § 601-609)).

Private Activity Bonds (PAB). A Private Activity Bond (PAB) is a form of tax-exempt bond instrument generated by or on behalf of a state or local government to finance qualifying projects. Under the current law, the maximum amount for bonds is $\$ 15$ billion with the exception of facility bonds (Section 11143 of Title XI of SAFETEA-LU). The allocation of the bonds is based on qualifying facilities. The primary advantage of PABs is the attraction of private developers and contractors to invest in projects with some public benefit with a low capital commitment (TIFIA Financing (23 U.S.C § 601-609)).

State Infrastructure Bank Credit Assistance (SIB). State Infrastructure Bank Credit Assistance (SIB) is a type of revolving funds administrated by the states that support surface transportation projects. Under the SAFETEA-LU, a new type of SIB program has been established supporting the leveraging of public investments by appealing for investments from private entities (TIFIA Financing (23 U.S.C § 601-609)). 
63-20 Public Benefit Corporation. A 63-20 Public Benefit Corporation (PBC) is a nonprofit corporation that is in compliance with the Internal Revenue Service (IRS) based on the IRS Rule 63-20 which can issue tax exempt instruments for private projects that can demonstrate activities that are public in nature and will benefit the public sector. These instruments can be used to finance highway projects where toll revenue is expected to pay back the debt (TIFIA Financing (23 U.S.C $\S 601-609)$ ).

Shadow Tolling and Availability Payments. A shadow toll is a variation of tolling to support financing of a highway project. These instruments are designated to pay back to the contractor an equal amount of money that the contractor would receive if a traditional toll was installed on the road. Another variation is the availability of payments to compensate a contractor in exchange to grant the public access to the public the facility (TIFIA Financing (23 U.S.C $\S 601-609)$ ). With the traditional approach, the environmental risks of the project are mostly retained by the government while the financial risk of the project should be allocated to the private sector. However, there are some external factors beyond the control of the partnering entities that are difficult to address prior to entering into a contract such as permits. In this case, a communication channel is needed to address how the burden of the project will be shared (TIFIA Financing (23 U.S.C $\S 601-609)$ ).

Resource Sharing. Another type of Public Private Partnership (PPP) is resource sharing. In this particular PPP, a private company grants considerations to a public agency. In the case of this study, a private company will obtain considerations from a public agency allowing the 
extraction of surface coal from specific areas. This PPP model will utilize the world's oldest form of trade, barter, or trading coal for a roadbed. This unique and sustainable method is the simplest solution for financing this endeavor. 


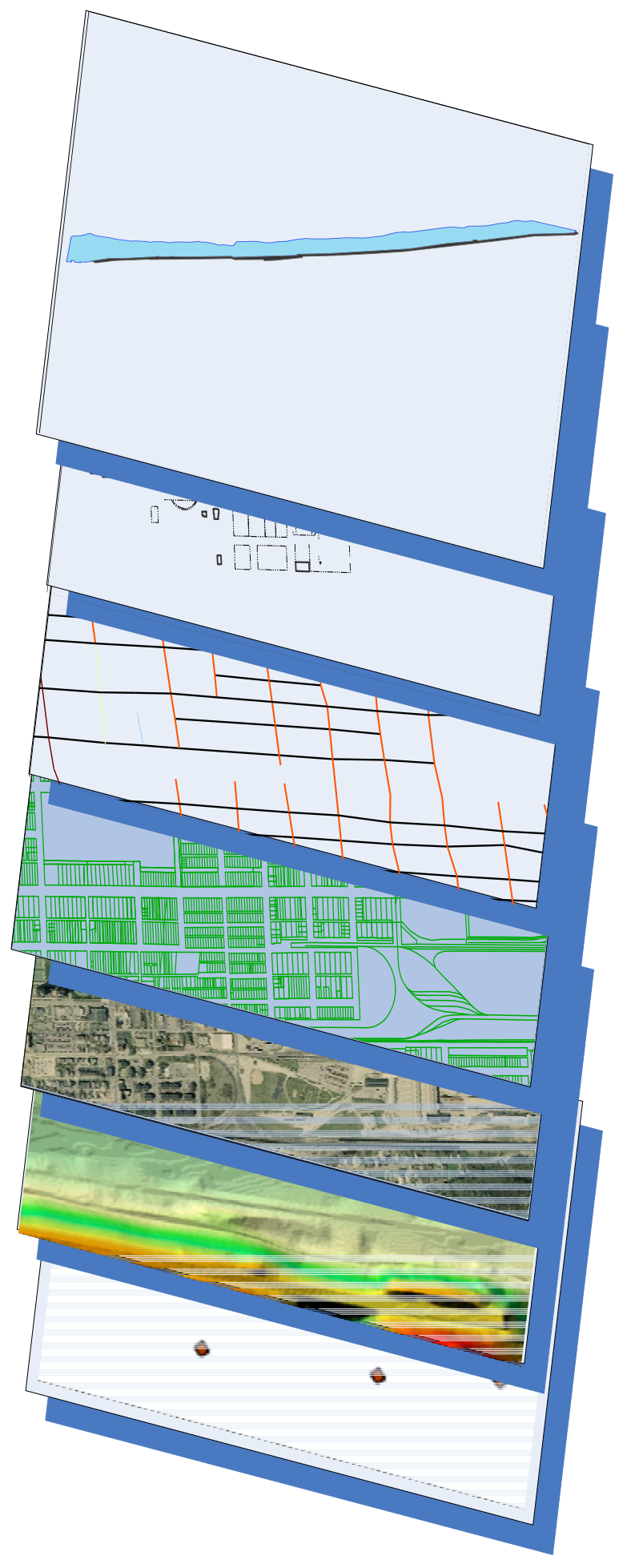

\title{
Natural Features
}

Master Land Use Plan

Roads

Cadastral Layer

Imagery

Digital Elevation Models

\author{
Minerals
}

Figure 23 Proposed UML and model 


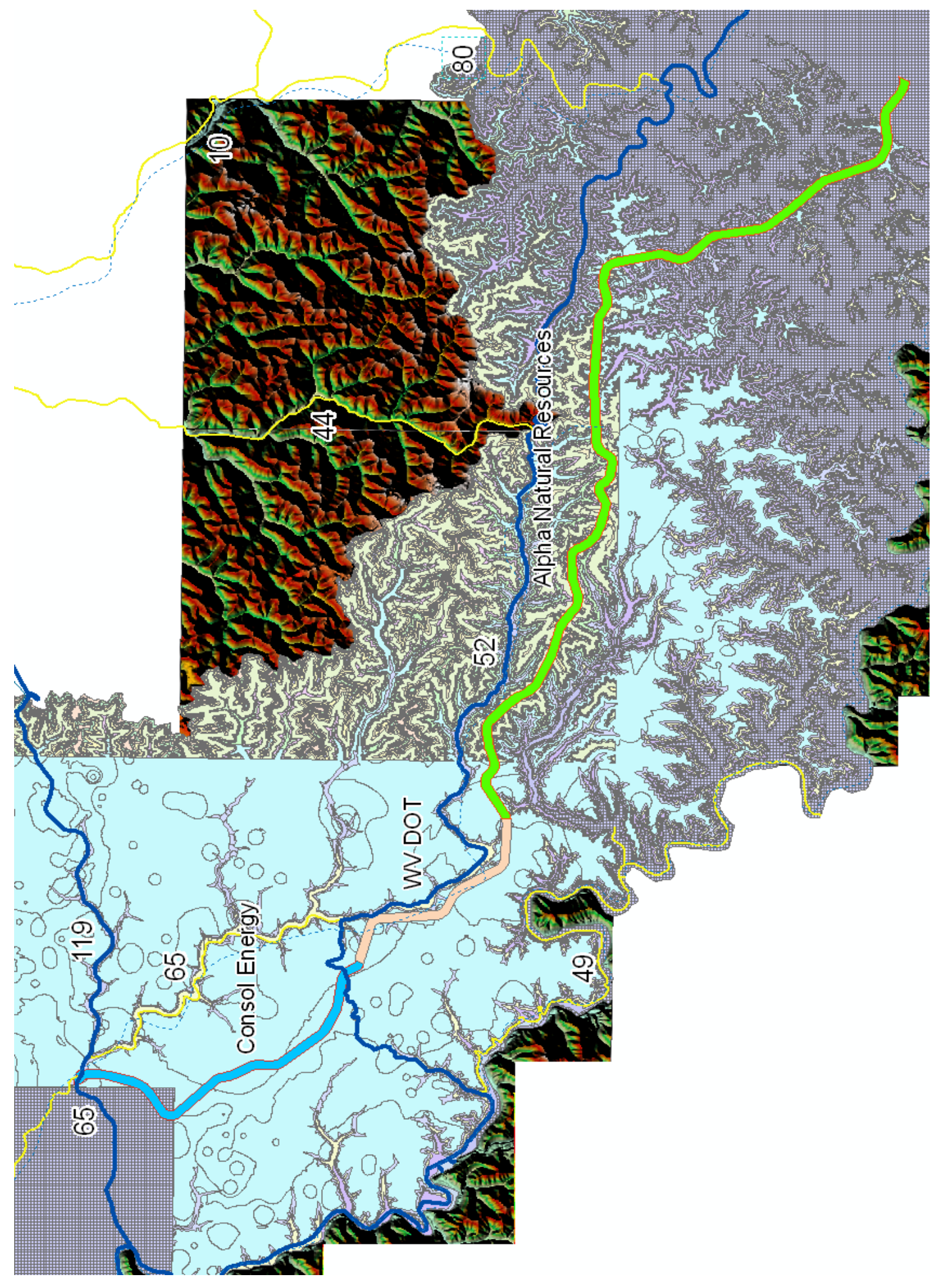

Figure 24 Preliminary Analysis 


\section{Corridor Selection}

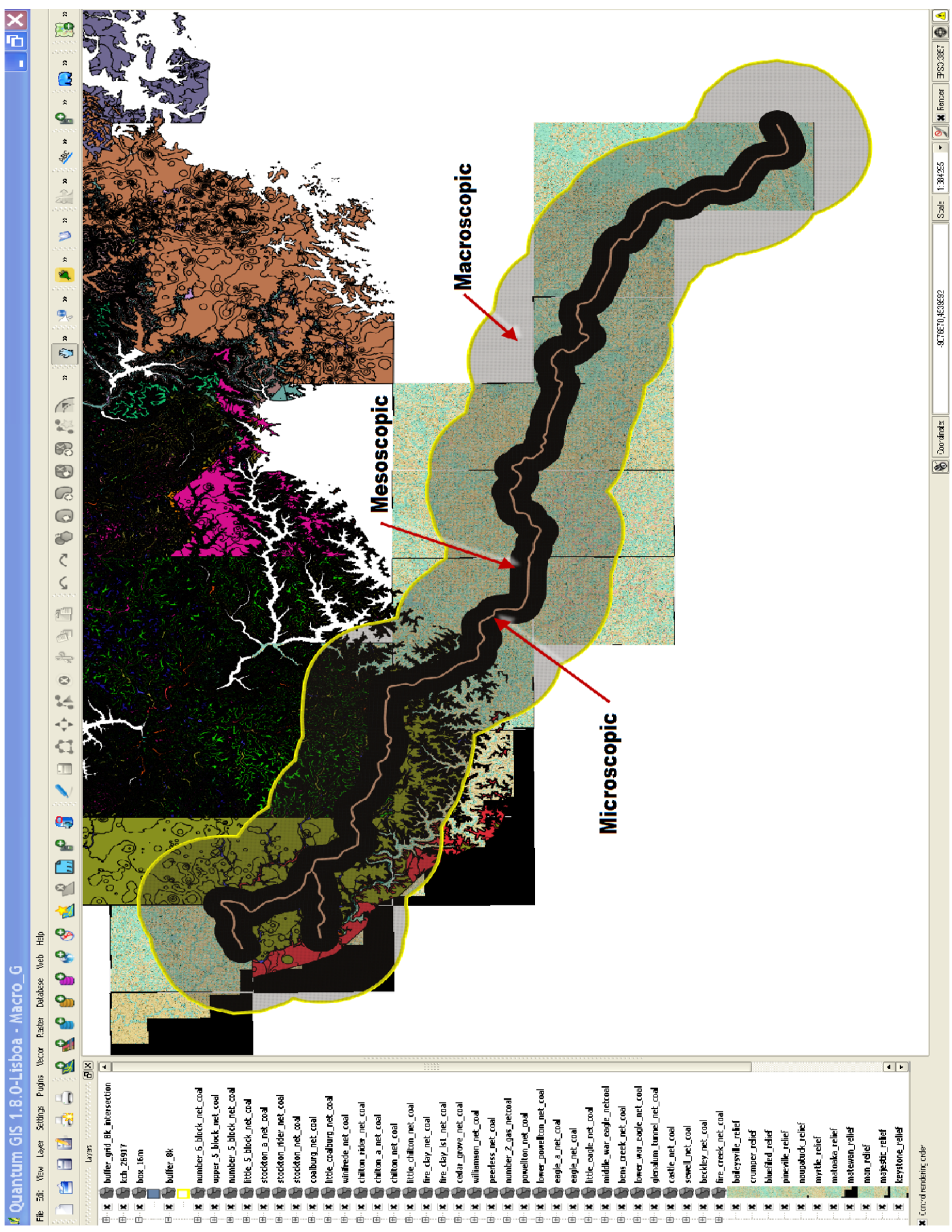

Map Created by Juan de Dios Barrios

Figure 25 King Coal Level View 


\section{Coal Seam Formations}

\begin{tabular}{|l|l|}
\hline Coal Seam & Formation \\
\hline Number_6 & Allegheny \\
\hline Upper_5 & Allegheny \\
\hline Number_5 & Allegheny \\
\hline Little_5 & Allegheny \\
\hline Stockton_A & Kanawha \\
\hline Stockton_Rider & Kanawha \\
\hline Stockton & Kanawha \\
\hline Coalburg & Kanawha \\
\hline Little_Coalburg & Kanawha \\
\hline Winifrede & Kanawha \\
\hline Chilton_Rider & Kanawha \\
\hline Chilton_A & Kanawha \\
\hline Chilton & Kanawha \\
\hline Little_Chilton & \\
\hline
\end{tabular}

Table 14 Coal Formations

Source West Virginia Geological \& Economic Survey 


\begin{tabular}{|c|c|c|c|c|c|}
\hline Series & Formation & Description & $\begin{array}{l}\text { Depth } \\
\text { Below Surface } \\
\text { (feet) }\end{array}$ & $\begin{array}{l}\text { Coal Thickness } \\
\text { (feet, unless } \\
\text { inches indicated }\end{array}$ & Coal Bed Name \\
\hline \multirow{8}{*}{ 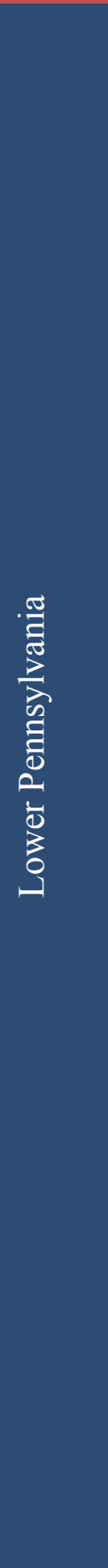 } & \multirow{5}{*}{ 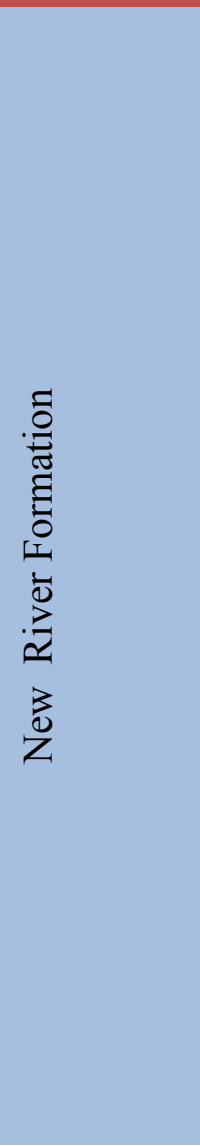 } & $\begin{array}{l}\text { Sandstone } \\
\text { Sandy Shale } \\
\text { Dark Shale } \\
\text { Sandstone } \\
\text { Coal spars } \\
\text { Sandstone }\end{array}$ & 12 & 3.0 Upper Bench & $\begin{array}{l}\text { Upper Horsepen Coal } \\
\text { Beds (Smith Seam) } \\
\text { Locally these beds } \\
\text { Merge }\end{array}$ \\
\hline & & $\begin{array}{l}\text { Sandy } \\
\text { Shale } \\
\text { Sandy } \\
\text { Shale } \\
\text { Sandstone }\end{array}$ & $\begin{array}{l}160.0 \\
203.0\end{array}$ & 4.0 Lower Bench & $\begin{array}{l}\text { Middle Horsepen Coal } \\
\text { Beds(s) }\end{array}$ \\
\hline & & $\begin{array}{l}\text { Shale } \\
\text { Sandstone }\end{array}$ & 282.0 & 1.5 & $\begin{array}{l}\text { War Creek Coal Bed } \\
\text { (Beckley Coal Bed) }\end{array}$ \\
\hline & & $\begin{array}{l}\text { Shale } \\
\text { Sandstone } \\
\text { Coal spars }\end{array}$ & $\begin{array}{l}332.0 \\
371.0\end{array}$ & $\begin{array}{l}0.5 \\
0.5 \\
8 " \\
0.5\end{array}$ & Fire Creek Coal Zone \\
\hline & & $\begin{array}{l}\text { Bone Coal } \\
\text { Pineville } \\
\text { Sandstone } \\
\text { Member }\end{array}$ & 468.0 & $\begin{array}{l}2.0 \\
1.0 \\
4 "\end{array}$ & $\begin{array}{l}\text { Lower Horsepen } \\
\text { Col Bed(s) } \\
\text { Little Fire Creek Coal } \\
\text { Zone (Company No. } 9 \\
\text { Coal Bed) }\end{array}$ \\
\hline & . & $\begin{array}{l}\text { Flattop } \\
\text { Mountain } \\
\text { Sandstone } \\
\text { Member } \\
\text { Black Shale } \\
\text { Sandstone } \\
\text { Shale }\end{array}$ & 616.0 & $2 "$ & $\begin{array}{l}\text { Pocahontas No.8 Coal } \\
\text { Bed }\end{array}$ \\
\hline & 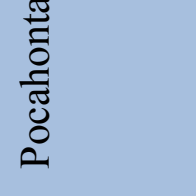 & $\begin{array}{l}\text { Grey shale } \\
\text { Sandstone } \\
\text { Shale }\end{array}$ & $\begin{array}{l}837.5 \\
854.0\end{array}$ & $\begin{array}{l}2.5 \\
4 " \\
5 " \\
7.0\end{array}$ & $\begin{array}{l}\text { Pocahontas No.4 } \\
\text { Coal Bed }\end{array}$ \\
\hline & & $\begin{array}{l}\text { Sandy shale } \\
\text { Shale1937.0 }\end{array}$ & $\begin{array}{l}948.0 \\
953.0\end{array}$ & 7.0 & $\begin{array}{l}\text { Pocahontas No. } 3 \\
\text { Coal Bed }\end{array}$ \\
\hline
\end{tabular}




\section{Code Examples}

\#\#\# System Information

SELECT postgis_full_version();

"POSTGIS="1.5.3" GEOS="3.2.2-CAPI-1.6.2" PROJ="Rel. 4.7.1, 23 September 2009"

LIBXML="2.7.8" USE_STATS"

\#\#\# Streams Analysis

SELECT cien_d.objectid as grid_number

FROM cien_d, streams

WHERE ST_Intersects(cien_d.shape, streams.shape);

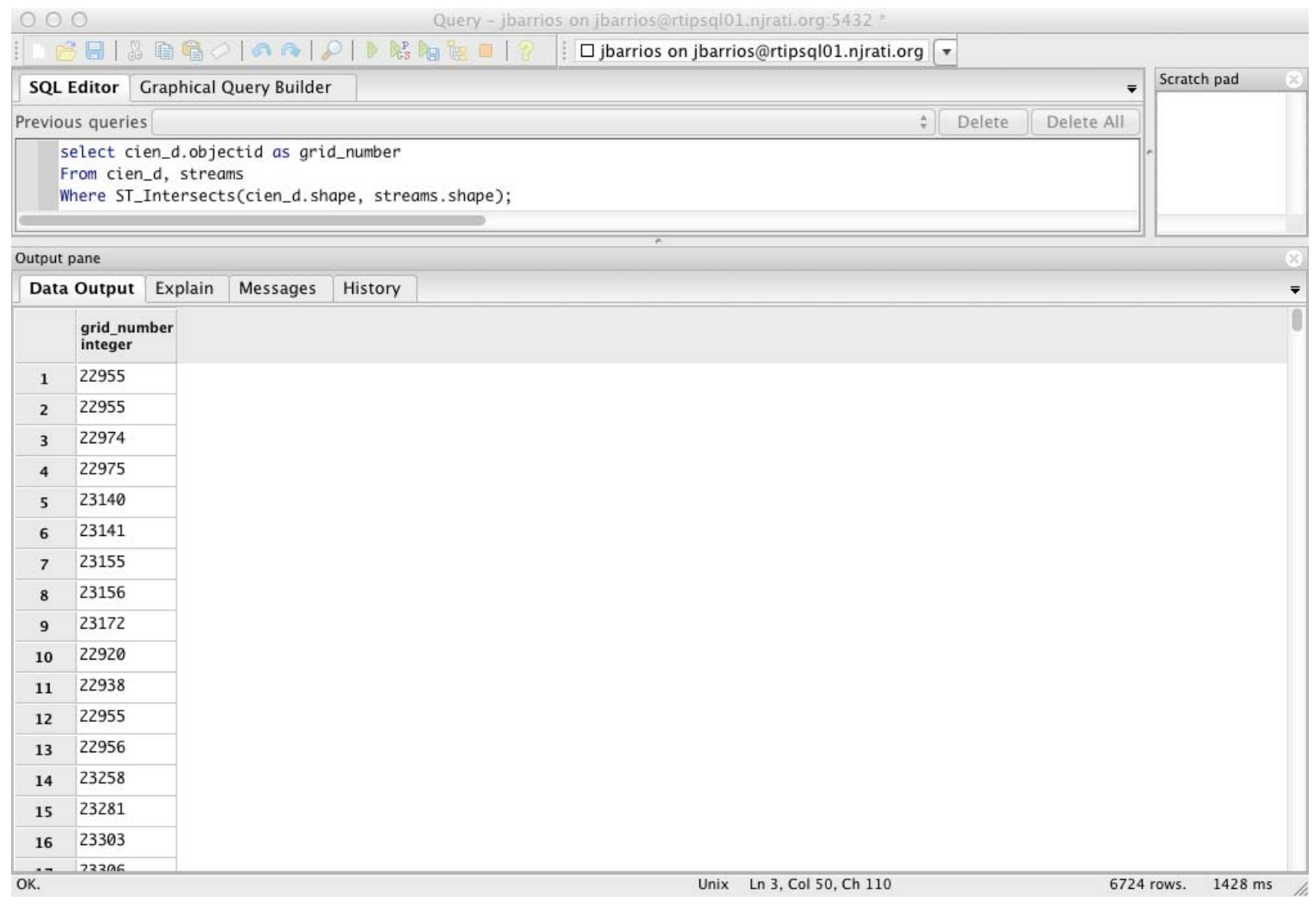




\section{Bibliography}

AECOM Consult Team. (2007). Case Studies of Transportation Public Private Partnerships in the United States. Washington, D.C.: Federal Highway Administration.

Akintola, A., Beck, M., \& Hardcastle, C. (2003). Public-Private Partnerships Managing Risk and Opportunities. Oxford, UK: Blackwell.

Ali, A. (2007, November 1). King Coal Highway Progresses One Piece at a Time. Retrieved March 7, 2011, from http://statejournal.com/story.cfm?func=viewstory\&storyid=30906

Alpha Natural Resources. (2008, April 4 ). Alpha Natural Resources to Commence Work on Coalfields Expressway After Virginia Designates Funds. Retrieved March 9, 2011, from Alpha Natural Resources, Inc. : http://alnr.client.shareholder.com/releasedetail.cfm?ReleaseID=303314

Archer, B. (2011, February 21). Transportation Could Push Progress on Coalfields Expressway. Retrieved March 9, 2011, from The Bluefield Daily Telegraph: http://bdtonline.com/local/x1405850072/Transportation-package-could-push-progress-onCoalfields-Expressway

ASCE. (n.d.). America's Infrastructure. Retrieved 8 25, 2011, from Roads: http://apps.asce.org/reportcard/index.cfm?reaction=factsheet\&page=1, site now discontinued

Beard, J. L., Loulakis, M. C., \& Wondram, E. C. (2001). Desing Build: planning through development. New York, NY 10121-2298: McGraw-Hill.

Beato, G. (2009, Jun). Barter Country. Reason, 41(2).

Bezdek, B. L. (2006-2007). To attain "the just rewards of so much struggle": local-resident equity participation in urban revitalization . HeinOnline . Hofstra L. Rev. .

Brachman, R. J., \& Levesque, H. J. (2004). Knowledge Representation. San Francisco, CA: Elsevier.

Buliung, R. K. (2005). GIS, objects and integrated urban models. In M. E.-G. Doherty, Integrated Landuse and Transportation Models: Behavioural Foundations (pp. 207-230). Oxford UK: Elsevier.

Cartlidge, D. P. (2006). Public Private Partnerships in Constructions. New York: Taylor $\backslash \&$ Francis.

Castle, M. J. (2011, October 28). King Coal Highway. (J. Barrios, Interviewer)

Coalfields Expressway Authority. (2000). Coalfields Expressway. Retrieved 12 26, 2010, from http://www.coalfieldsexpressway.com/

Congress, U. (1803, 2 19). An act Authorizing Sale of Land in Charleston Massachusetts. The Public States at Large of The United States of America.

Daniels, R., \& Trebilcock, M. (1996). Private Provision of Public Infrastructure: An Organizational Analysis of the Next Privatization Frontier. University of Toronto Law Journal, 375-426. 
Eduardo Engel, R. F. (2011, January). The Basic Public Finance of Public-Private Parnerships. Retrieved August 1, 2011, from Cowles Econ Yale: http://cowles.econ.yale.edu/

El-Gafy, N. A. (2005). Dissertation "Environmental Impact Assessment of Transportation Projects: An Analysis Using and Integrated GIS, Remote Sensing, and Spatial Modeling Aproach". Florida State University.

Environmental Systems Research Institute. (2010). Performing Analysis with ArcGIS Desktop. Redlands, Ca.: ESRI Press.

European Commission. (2004, March). Guidelines for Successful Public-Private Partnerships. Retrieved September 8, 2011, from European Commission Directorate-General Regional Policy: http://ec.europa.eu/regional_policy/sources/docgener/guides/ppp_en.pdf

Federal Highway Administration. (2008, February 25). "Remarks for the Honorable Mary Peters, Secretary of Transportation,". Retrieved August 12, 2011, from http://financecommission.dot.gov/Documents/02-25-08NGAPlenary.doc

Federal Highway Administration. (n.d.). Case Studies: King Coal Highway. Retrieved March 7, 2011, from http://www.fhwa.dot.gov/ipd/case_studies/wv_kingcoal.htm

Federal Highway Administration. (n.d.). Innovate Program Deliver. Retrieved 12 26, 2010, from U.S. Departament of Transportation Federal Highway Administration: http://www.fhwa.dot.gov/ipd/index.htm

Fisher, K. K. (1993). Sophisticated and distributed: The transportation domain. Artificial Intelligence for Applications, 1993. Proceedings., Ninth Conference on, 454.

Flyvbjerg, B., Skamris Holm, M. K., \& Buhl, S. L. (2004). What Causes Cost Overrun in Transport Infrastructure Projects? Transport Reviews, 3-18.

Fotheringham, S. A. (2001). GIS-Based Spatial Modeling: A Step Forwad or a Step Backwards. In S. Fotheringham, \& M. Wegner, Spatial Models and GIS: New Potential New Models (pp. 21-31). Philadelphia : Taylor \& Francis.

Fotheringham, S. A., \& Rogerson, P. A. (2009). The SAGE Handbook of Spatial Analysis. London: SAGE.

Fotheringham, S. A., \& Wegner, M. (2000). Spatial Models and GIS. Philadelphia, PA: Taylor \& Francis.

Fotheringham, S. A., Brunsdon, C., \& Charlton, M. (2002). Geographically Weighted Regression. The analysis of spatially varying relationships. West Sussex: Wiley.

Galilea, P. A., \& Medda, F. (2009, January and February). Analyzing the Influence of National Political and Economical Factors on the Success pf Public-Private Parnerships in Transport. University College London, 25. 
Ganz, K. (2009, March 4). A\&O, Freshfields join US firms in push on P3. Retrieved September 2, 2011, from The Lawyer: http://www.thelawyer.com/ao-freshfields-join-us-firms-in-push-onp3/136985.article

Garvin, M. (2007). America’s Infrastructure Strategy: Drawing on History to Guide the Future. Retrieved August 17, 2011, from http://crgp.stanford.edu/events/presentations/CA/CRGP_KPMG_whitepaper.pdf

Goodchild, M. F. (1992). Geographical Information Science. International Journal of Geographical Information Systems, 31-45.

Gordon H. Wood, J., \& Thomas M. Kehn, M. D. (2003, March 31). Coal Resource Classification System of the U.S. Geological Survey. Retrieved December 7, 2010, from U.S. Geological Survey: http://pubs.usgs.gov/circ/c891/glossary.htm

Haining, R. (1990). Spatial Data Analysis in the Social and Environmental Sciences. Cambridge: Cambridge University Press.

Haining, R. (2003). Spatial Data Analysis Theory and Practice. New York: Cambridge.

HM Treasury. (n.d.). Public Private Partnerships. Retrieved September 7, 2011, from HM Treasury : http://www.hm-treasury.gov.uk/ppp_index.htm

Innovation Briefs . (2007, July/August). The Public-Private Parnerships Debate Take a New Turn.

Jensen, J. R. (2005). Introductory Digital Image Processing - A Remote Sensing Perspective. Upper Saddle River, NJ: Pearson Pretince Hall.

Judith W. Wegner, J. (1987). Public and Private Partnerships for Financing Highway Improvements. Washington, D.C.: National Cooperative Highway Research Program.

Kabler, P. (2011, March 3). W.Va. Senate kills U.S. 35 toll plan. Retrieved March 4, 2011, from http://wvgazette.com/News/Putnam/201103031149?page=1

Keeter, B. (2004, May 7). Federal Highway Administrator Touts Administration Investment in King Coal Highway; Praises Jobs, Economic Opportunity It Will Bring to Appalachia. Retrieved March 7, 2011, from Federal Highway Administration: http://www.fhwa.dot.gov/pressroom/fhwa0405.htm

Kwak, Y. H., Chih, Y. Y., \& Ibbs, W. (2009). Towards a Comprehensive Understanding of Public Private Partnerships for Infrastructure Development. California Management Review, 51.

Landis, J. D., \& Zhang, M. (2000). Using GIS to Improve Urban Activity and Forecasting Models: Three Examples. In A. Vernez Moudon, \& M. Hubner, Monitoring Land Supply with Geographic Information Systems (pp. 63-81). New York: John Wiley \& Sons, Inc.

Larsen, L. (1999). GIS in environmental monitoring and assessment. In P. A. Longley, M. F. Goodchild, D. J. Maguire, \& D. W. Rhind, Geographical Information Systems Volume 2 (pp. 999-1008). New York: John Wiley \& Sons, Inc. 
Lee, D. W. (2005). Statistical Analysis of Geographic Information with Arc View GIS and ArcGIS. New Jersey: Wiley and Sons.

Li, B., Edwards, P., \& Hardcastle, C. (2005). Perceptions of positive and negative factors influencing the attractiveness of PPP/PFI procurement for construction projects in the UK. Engineering, Construction and Architectural Management, 125-148.

Longley, P. A., Goodchild, M. F., Maguire, D. J., \& Rhind, D. W. (2005). Geographic Information Systems and Science. West Sussex, England: John Wiley \& Sons.

Mallett, W. J. (2008). Public-Private Partnerships in Highway and Transit Infrastructure Provision. Washington, DC: Library of the Congress.

Mandelbrot, B. (1989). Fractal Geometry: What is it, and what doest it do? Proc. R. Soc. London A 423, 3-16.

Miller, H. (2001). Geographic Information Systems for Transportation. New York: Oxford Univeristy Press.

Miller, J. B. (2000). Pinciples of Public and Private Infrastructure Delivery. Massachusetts: Kluwer Academic Publishers.

Mineta, N. Y. (n.d.). (R. Roberts, Interviewer) Springboard.

Mitchem, M. M. (2009, May 6). Economic Impact of I-73 on the I-73 Corridor in West Virginia. Retrieved November 24, 2009, from King Coal Highway Authority: http://www.chmuraecon.com/pdfs/Chmura_Economic_Impact_I73_in_WVA.pdf

Munnell, A. H. (N.A). Is There a Shothfall in Public Capital Investment? An Overview. Federal Reserve Bank of Boston (pp. 1-20). Boston: Federal Reserve Bank of Boston.

National Archives and Records Administration. (2009). Code of Federal Regulations 30 Mineral Resources. Washington, DC: U.S. Goverment Printing Office.

National Cooperative Highway Research Program. (2009). Legal Research Digest 51. Washington, D.C.: Transportation Research Board of the National Academies.

National I-73/74/75 Corridor Association. (n.d.). National I-73/74/75 Corridor Association. Retrieved February 23, 2013, from National I-73/74/75 Corridor Association: http://www.i73.com/

National Surface Transportation Policy and Revenue Study Commission. (2006, October 27). Portland Field Hearing. Portland, Oregon.

National Surface Transportation Policy and Revenue Study Commission. (2008). Transportation for Tomorrow. Metropolitan Transportation Commission.

Newman, D. G., Lavelle, J. P., \& Eschenbach, T. G. (2002). Engineering Economic Analysis. Oxford: Oxford University Press. 
Open Geospatial Consortium. (2013). Open Geospatial. Retrieved February 20, 2013, from OGC: http://www.opengeospatial.org/

Papajohn, D., Cui, Q., \& Bayraktar, M. E. (2011). Public Private Partnerships in U.S. Transportation: Research Overview and a Path Forward. Journal of Management in Engineering, July.

Parsons, J. C. (2010, 8). Public-Private Partnerships Need an Educated Public. ENR: Engineering NewsRecord, 265(3).

Peter W. Hahn, J. (2011, May 23). Prevailing Wage Laws: What Are They and How Are They Changing? Columbus, Ohio.

pgadmin.org. (2009, 03 26). pgAdmin PostreSQL Tools. Retrieved 11 27, 2012, from http://www.pgadmin.org/

Poole, R., \& Samuel, P. (2006, March/April). The Return of Private Toll Roads. Public Roads. U.S. Departament of Transportation Federal Highway Administration.

Quantum GIS Development Team (YEAR). (2012). Quantum GIS Geographic Information System. Open Source Geospatial Foundation Project. Retrieved 11 27, 2012, from Quantum GIS: http://qgis.osgeo.org

Quattrochi, D. A., \& Goodchild, M. F. (1997). Scale in Remote Sensing and GIS. Boca Raton FL: CRC .

Queiroz, C. (2005, September). The World Bank Group. Retrieved September 8, 2011, from Transport Papers: http://www-

wds.worldbank.org/external/default/WDSContentServer/WDSP/IB/2005/10/24/000160016_2005 1024091948/Rendered/PDF/33910a10trp090PPPs0Highways.pdf

Rahall Transportation Institute and Center for Business and Economic Research. (2011). Potential Economic Benefits of Public Private Partnerships on Reclaimed Mine Sites in Construction of the King Coal Highway (White Paper). Huntington, West Virginia, USA.

Rahall, N. (2011, February 14). Project Vote Smart. Retrieved from Transportation Panel Gathers Information in Beckley: http://votesmart.org/public-statement/591433/transportation-panelgathers-information-in-beckley\#.US1sCkfEHRM

Ronald N. Buliung, P. K. (2005). GIS, Objects and Integrated Urban Models. In M. Lee-Gosselin, \& S. Doherty, Integrated Land-Use and Transportation Models; Behavioural Fundations (pp. 207230). Oxford, UK: Elsevier.

South Carolina Department of Transportation. (2007). Environmental Impact Study. Retrieved 12 26, 2010, from Final Environmental Impact Statement: http:/www.i73insc.com/

South Carolina DOT. (2007). i73insc.com. Retrieved November 24, 2009, from Environmental Impact Study: http://www.i73insc.com/ 
Spiekermann, K., \& Wegner, M. (2001). Freedom from the Tyranny of Zones: Towards New GIS-Based Models. In S. Fotheringham, \& M. Wegner, Spatial Models and GIS: New Potential New Models (pp. 45-62). Philadelphia, PA: Taylor\& Francis.

State of West Virginia . (2012, January 11). Departament of Revenue. Retrieved from State Tax Departament: http://www.state.wv.us/taxrev/administrativeNotices/2012/administrativeNotice.2012-02.pdf

State of West Virginia. (2006, May 1). West Virginia Legislative Rule Departament of Tax and Revenue Division of Tax. Retrieved 12 7, 2010, from West Virginia Secretary of State: http://apps.sos.wv.gov/adlaw/files/rulespdf/110-01I.pdf

Sturm, J. C. (2011). Analysis of cost estimation disclosure in environmental impact statements for surface transportation projects. Transportation, 38(3), 525-544.

Sullivan, W. G., Wicks, E. M., \& Luxhoj, J. T. (2005). Engineering Economy Thirteenth Edition. New Jersey: Pearson Prentice Hall.

Sussman, J. M. (2005). Perspectives on Intelligent Transportation Systems. New York, NY: Springer.

The Associated Press. (2011, February 22). Census: Near-record Level of US Counties Dying.

The Canadian Council for Public-Private Partnerships . (2011). Definitions. Retrieved September 8, 2010, from The Canadian Council for Public-Private Partnerships: http://www.pppcouncil.ca/resources/about-ppp/definitions.html

The National Council for Public Private Partnerships. (n.d.). How PPPs Work. Retrieved September 8, 2011, from The National Council for Public Private Partnerships: http://www.ncppp.org/howpart/index.shtml\#define

The PostgreSQL Global Development Group . (2012). PostgreSQL. Retrieved 11 27, 2012, from PostgreSQ: http://www.postgresql.org/

The PostgreSQL Global Development Group. (2012). PostgreSQL 9.1.6 Documentation. The PostgreSQL Global Development Group.

Transportation Research Board. (1998). Economic Impact Analysis of Transit Investments: Guide for Practitioners. Washington, D.C.: The Federal Transit Administration.

Turochy, R. E., Hoel, L. A., \& Doty, R. S. (2001). Highway Project Cost Estimating Methods Used in the Planning Stage of Project Development. Charlottesville, Va: Virginia Transportation Research Council.

U.S. Departament of the Interior. (1982). Chemical Analysesand Physical Properties of 12 Coal Samples from the Pocahontas Field, Tazewell County, Virginia, and McDowell County, West Virginia. Washington D.C.: United States Goverment Printing Office.

U.S. Departament of Transportation. (2004). Report to Congress on Public-Private Partnerships. Washington, DC: FHWA. 
U.S. Departament of Transportation Federal Highway Administration. (2010). 2010 Status of the Nation's Highways, Bridges, and Transit: Conditions \& Performance. Report to the Congress . Washington, DC: US DOT .

U.S. Departament of Transportation Federal Highway Administration. (n.d.). Construction. Retrieved August 8, 2011, from Federal Highway Administration: http://www.fhwa.dot.gov/construction/cqit/sep14.cfm

U.S. Departament of Transportation. (n.d.). National Pipeline Mapping System. Washington, D.C, USA.

U.S. Departament of Transportation Research and Innovative Technology Administration. (1991, January 3). RITA. Retrieved February 21, 2013, from National Transportation Library: http://ntl.bts.gov/DOCS/istea.html

U.S. Department of Transportation - Federal Highway Administration. (n.d.). National Environmental Policy Act Implementation. Retrieved April 16, 2011, from NEPA Implementation: http://www.environment.fhwa.dot.gov/projdev/pd2implement.asp

U.S. Energy Information Administration. (2013, January). Annual Energy Outlook 2013. AEO2013 Early Release Overview.

United States Department of Labor. (n.d.). Davis Bacon and Related Acts. Retrieved March 7, 2011, from http://www.dol.gov/whd/contracts/dbra.htm

Universidad Politécnica de Valencia. (2011, July 19). Jaspa 0.2.0. Retrieved 11 27, 2012, from http://jaspa.upv.es/jaspa/v0.2.0/manual: http://jaspa.upv.es/jaspa/v0.2.0/manual/html/ST_Disjoint.html

Vassallo, J. M., Baeza, M. d., \& Ortega, A. (2011, January 24). Toll highway conseeions in the Madrid Metropolitan Area: Lesson to be learnt from unsuccessful experience. Transportation Research Board. Washington, D.C.: TRB.

Vemez, A. (2000). Monitoring Land Supply with Geographic Information Systems: Theory, Practice and Parcel-Based Approaches. In J. Landis, \& Z. Ming, Using GIS to Improve Urban Activity and Forecasting Models: Three examaples (pp. 63-81). New York: John Wiley.

Vernez, A. (2000). Monitoring Land Supply with Geographic Information Systems : Theory, Practice, and Parcel-Based Approaches. New York: John Wiley.

Virginia Department of Transportation. (2006, November 30). Status of Coalfields Expressway and Coalfields Connector: Appropriation Act Item 443 D. Retrieved September 6, 2011, from Virginia Department of Transportation: http://www.virginiadot.org/projects/resources/Coalfields_Final_Report_-_VDOT_website.pdf

Virginia Department of Transportation. (2008, September 22). Press Release. VDOT to advance Hawk's Nest portion of Coalfields Expressway. Bristol, Virginia. 
Virginia Department of Transportation. (2008, September 10). Second Amendment to Assignment and Assumption Agreement. Retrieved March 9, 2011, from Virginia Department of Transportation: http://www.virginiadot.org/projects/resources/Bristol/CFXPP_SecondAmendment_080910.pdf

Virgnia General Assambly. (1994). Legislative Information System. Retrieved from Code of Virginia Title 56 Public Serive Companies : http://leg1.state.va.us/cgibin/legp504.exe?000+cod+TOC56000000022000000000000

Watson, W. (2007). ArcView Coal Evaluation User's Guide. U.S. Department of the Interior. Reston, Virginia: U.S. Geological Survey.

West Virginia Departament of Highways. (2010, October 26). Desing Directives. Retrieved May 13, 2011, from West Virginia Departament of Transportation: http://www.transportation.wv.gov/highways/engineering/DD/2006\%20DD\%20Manual\%20MAS TER.pdf

West Virginia Departament of Transportation. (2000, June). King Coal Highway. Final Environmental Impact. West Virginia, United States of America: West Virginia Departament of Transportation Division of Highways.

West Virginia Departament of Transportation. (2006, June 16). DD-200 Project Development Process. Charleston, West Virginia.

West Virginia Departament of Transportation. (2012). State of West Virginia Departament of Transportation. Retrieved April 17, 2012, from Average Unit Bid Prices: http://www.transportation.wv.gov/highways/contractadmin/Lettings/Pages/AverageUnitBidPrices .aspx

West Virginia Department of Transportation. (2010, June 15). Progress Continues on the New US Route 35. Retrieved February 28, 2011, from West Virginia Department of Transportation: http://www.transportation.wv.gov/communications/Press-

Release/Pages/ProgressContinuesontheNewUSRoute35.aspx

West Virginia Department of Transportation, Division of Highways. (1994). King Coal Highway Purpose and Need Study. Charleston: WVDOT.

West Virginia Geological \& Economic Survey. (2009, August 13). Interactive Coal Maps. Morgantown, West Virginia, USA. Retrieved from http://www.wvgs.wvnet.edu/www/coal/cbmp/coalimsframe.html

West Virginia GIS Technical Center. (2013, September 1). WV State GIS Data Clearinghouse. Retrieved from http://wvgis.wvu.edu/data/data.php

West Virginia Legislative Rules State Tax Comission. (1991, July 26). Valuation of Active and Reserve Coal Property for Ad Valorem Property Tax Purposes. Charleston, West Virginia, US.

West Virginia Legislature. (2010). West Virginia Code. Retrieved 12 26, 2010, from Chapter 17. Roads and Highways: http://www.legis.state.wv.us/WVCODE/Code.cfm?chap=17\&art=27 
Wilson, J. (1999). Local, National, and Global Applications of GIS in Agriculture. In P. A. Longley, M. F. Goodchild, D. J. Maguire, \& D. W. Rhind, Geographical Information Systems Volume 2 (pp. 981-998). New York: John Wiley \& Sons, Inc.

World Bank. (2001). PPP in Infrastructure Resource Center. Retrieved September 8, 2011, from World Bank: http://go.worldbank.org/OS6V7NIUD0

WV Department of Transportation. (2004, May 6). KCH Red Jacket Section Mingo County. Division of Highways Agreement for State project U330-52-30.34 Nicewonder Contracting, INC . Charleston: West Virginia Department of Transportation. 